\title{
PRODUÇÃO DE FORRAGEM, MASSA E CRESCIMENTO DE RAÍZES DOS CAPINS ARUANA E TANZÂNIA SUBMETIDOS A DOSES DE NITROGÊNIO, EM LOTAÇÃO ROTACIONADA COM OVINOS
}

\author{
ALESSANDRA APARECIDA GIACOMINI \\ Zootecnista
}

Orientador: PROF. DR. HERBERT BARBOSA DE MATTOS

Dissertação apresentada à

Escola Superior de Agricultura "Luiz de Queiroz", Universidade de São Paulo, para obtenção do título de Mestre em Agronomia, Área de Concentração: Ciência Animal e Pastagens.

PIRA C I C A B A

Estado de São Paulo - Brasil

Dezembro-2003 


\section{Errata}

Autor: Alessandra Aparecida Giacomini

Titulo da Dissertação: Produção de forragem, massa e crescimento de raizes dos capins Aruana e Tanzânia submetidos a doses de nitrogênio, em lotação rotacionada com ovinos.

\begin{tabular}{|c|c|c|c|c|}
\hline p. & item & linha & onde se lê & leia-se \\
\hline 32 & 4.1 .2 & 12 & R4: 77 dias & R4: 70 dias \\
\hline 32 & 4.1.2 & 18 & $55,6^{\mathrm{BC}}$ & $65,0^{A}$ \\
\hline 32 & 4.1 .2 & 18 & $24,6^{C D}$ & $22,0^{B}$ \\
\hline 32 & 4.1 .2 & 18 & $13,1^{\mathrm{D}}$ & $23,0^{8}$ \\
\hline 32 & 4.1 .2 & 18 & $54,7^{\mathrm{BC}}$ & $31,5^{\mathrm{B}}$ \\
\hline 32 & 4.1 .2 & 18 & $75,1^{A B}$ & $77,7^{A}$ \\
\hline 32 & 4.1 .2 & 18 & $92,6^{A}$ & $78,1^{A}$ \\
\hline 32 & 4.1 .2 & 19 & 10,08 & 9,07 \\
\hline 32 & 4.1.2 & 19 & 10,09 & 7,42 \\
\hline 32 & 4.1.2 & 19 & 10,09 & 5,71 \\
\hline 32 & 4.1 .2 & 19 & 10,09 & 5,32 \\
\hline 32 & 4.1 .2 & 19 & 10,09 & 8,22 \\
\hline 32 & 4.1.2 & 19 & 10,08 & 11,12 \\
\hline 64 & Apêndice & 14 & R1: 49 & $\mathrm{R} 1: 43$ \\
\hline 64 & Apêndice & 14 & R2: 43 & R2: 49 \\
\hline 64 & Apêndice & 14 & R3: 77 & R3: 43 \\
\hline 64 & Apêndice & 14 & R4: 38 & R4: 70 \\
\hline 64 & Apêndice & 14 & R5: 43 & R5: 38 \\
\hline 64 & Apêndice & 14 & R6: 35 & R6: 43 \\
\hline 64 & Apêndice & 23 & $43,4^{a}$ & $49,2^{a}$ \\
\hline 64 & Apêndice & 23 & $19,5^{a}$ & $18,2^{a}$ \\
\hline 64 & Apêndice & 23 & $11,2^{a}$ & $20,0^{a}$ \\
\hline 64 & Apêndice & 23 & $67,5^{\mathrm{a}}$ & $35,5^{a}$ \\
\hline 64 & Apêndice & 23 & $66,4^{a}$ & $72,1^{a}$ \\
\hline 64 & Apêndice & 23 & $90,0^{a}$ & $77,6^{a}$ \\
\hline 64 & Apêndice & 23 & $49,7^{a}$ & $45,4^{a}$ \\
\hline 64 & Apêndice & 23 & 6,87 & 5,30 \\
\hline 64 & Apêndice & 24 & $67,9^{a}$ & $80,9^{a}$ \\
\hline 64 & Apêndice & 24 & $29,7^{a}$ & $25,8^{a}$ \\
\hline 64 & Apêndice & 24 & $14,9^{a}$ & $26,0^{a}$ \\
\hline 64 & Apêndice & 24 & $41,8^{a}$ & $27,6^{\mathrm{a}}$ \\
\hline 64 & Apêndice & 24 & $83,8^{a}$ & $83,2^{a}$ \\
\hline 64 & Apêndice & 24 & $95,1^{a}$ & $78,6^{\mathrm{a}}$ \\
\hline 64 & Apêndice & 24 & $55,5^{a}$ & $53,7^{a}$ \\
\hline 64 & Apêndice & 24 & 6,94 & 5,37 \\
\hline 64 & Apêndice & 26 & $57,5^{\mathrm{a}}$ & $67,0^{\mathrm{a}}$ \\
\hline 64 & Apêndice & 26 & $16,4^{a}$ & $15,0^{\mathrm{a}}$ \\
\hline 64 & Apêndice & 26 & $11,5^{a}$ & $20,0^{a}$ \\
\hline 64 & Apêndice & 26 & $47,2^{a}$ & $29,2^{\mathrm{a}}$ \\
\hline 64 & Apêndice & 26 & $71,5^{a}$ & $69,6^{a}$ \\
\hline 64 & Apêndice & 26 & $88,0^{a}$ & $75,5^{\mathrm{a}}$ \\
\hline 64 & Apêndice & 26 & $48,7^{a}$ & $46,1^{a}$ \\
\hline 64 & Apêndice & 26 & 5,72 & 5,30 \\
\hline 64 & Apêndice & 27 & $53,7^{a}$ & $63,1^{a}$ \\
\hline 64 & Apêndice & 27 & $21,8^{a}$ & $29,0^{a}$ \\
\hline 64 & Apêndice & 27 & $14,6^{a}$ & $26,0^{a}$ \\
\hline 64 & Apêndice & 27 & $62,2^{a}$ & $33,8^{a}$ \\
\hline 64 & Apêndice & 27 & $78,7^{a}$ & $85,7^{a}$ \\
\hline 64 & Apêndice & 27 & $97,2^{a}$ & $80,8^{a}$ \\
\hline 64 & Apêndice & 27 & $56,5^{a}$ & $53,1^{a}$ \\
\hline 64 & Apêndice & 27 & 7,91 & 5,37 \\
\hline
\end{tabular}




\title{
Dados Internacionais de Catalogação na Publicação (CIP) DIVISÃO DE BIBLIOTECA E DOCUMENTAÇÃO - ESALQ/USP
}

\author{
Giacomini, Alessandra Aparecida \\ Produção de forragem, massa e crescimento de raizes dos capins aruana e tanzânia \\ submetidos a doses de nitrogênio, em lotação rotacionada com ovinos / Alessandra \\ Aparecida Giacomini. - Piracicaba, 2003. \\ 66 p. : il. \\ 2004. \\ Dissertação (mestrado) - Escola Superior de Agricultura Luiz de Queiroz, \\ Bibliografia. \\ 1. Adubação 2. Capim coloniāo 3. Capim-tanzânia 4. Forragem 5. Nitrogênio 6 \\ Ovinos 7. Pastejo 8. Raiz I. Título
}

CDD 633.2 
Aos meus pais, José e Maria Valéria, pelo exemplo de vida, dedicação, grande incentivo e amor incondicional,

Ao meu irmão Guilherme, pelo amor, amizade e companheirismo,

Dedico 


\section{AGRADECIMENTOS}

A Deus, que me acompanha em todos os momentos.

Ao Prof. Dr. Herbert Barbosa de Mattos, pela confiança, ensinamentos e oportunidade oferecida.

Aos Pesq. Cient. do Instituto de Zootecnia de Nova Odessa/SP, Dr. Eduardo Antonio da Cunha, Dr. Luis Eduardo dos Santos, e Dr. Mauro Sartori Bueno, pela oportunidade, confiança, amizade, apoio técnico e infraestrutura oferecida.

Aos Pesq. Cient. do Instituto de Zootecnia de Nova Odessa/SP, Dr. Joaquim Carlos Werner e Dra. Maria Tereza Colozza, pela amizade, ensinamentos, colaboração e infraestrutura oferecida.

À Pesq. Cient. do Instituto de Zootecnia de Nova Odessa/SP, Dra. Dora Duarte de Carvalho, pela amizade verdadeira, colaboração, ensinamentos, troca de idéias e experiências.

Ao Instituto de Zootecnia de Nova Odessa/SP, pelo fornecimento da infraestrutura para a realização desse trabalho.

Aos amigos Dra. Luciana Gerdes e Dr. Waldssimiller Teixeira de Mattos, pela grande amizade, paciência, companheirismo e ajuda no decorrer do trabalho.

Aos funcionários do Instituto de Zootecnia de Nova Odessa/SP, Maria de Lourdes T. Santiago, Onofre Martins, Mauro Bertolai, Paulo Pereira dos Santos, José Sperchi, Joaquim do Nascimento, Flávio R. de Jesus e Antônio Marco Pigato, pelo apoio, amizade e torcida.

Ao coordenador do curso de Nutrição Animal e Pastagens, prof. Dr. Sila Carneiro da Silva, pelos ensinamentos e ajuda no decorrer do trabalho.

Ao prof. Dr. Francisco Antonio Monteiro, pelos ensinamentos e amizade.

Ao CNPq, pela concessão da bolsa de estudo.

À FAPESP, pelo financiamento do projeto. 
Às amigas/irmãs Luciana Gerdes e Suzana Pereira de Melo, pela presença constante e amizade verdadeira.

À Michele Nazaré Xavier Costa e Patrícia Sarmento, pela amizade, ajuda e troca de informações.

Às amigas piracicabanas Denise Ometto e Virginia Altafin, pela hospitalidade e companheirismo.

À tia Maria do Carmo Gimenez, e primos Marcia e Pedro Forner, pelo amor e torcida.

Aos meus pais, José e Maria Valéria, e ao meu irmão Guilherme, que me apoiaram e incentivaram sempre, com confiança e paciência, obrigada por serem tão maravilhosos. 


\section{SUMÁRIO}

Página

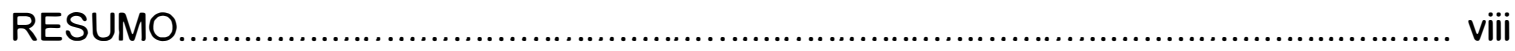

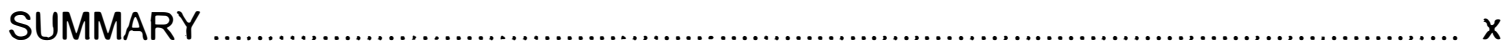

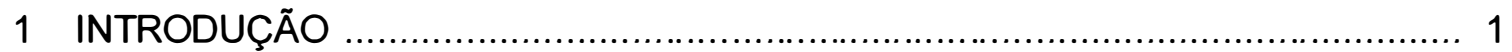

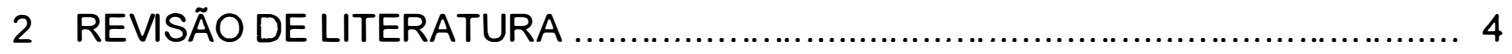

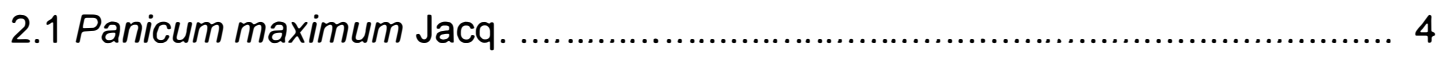

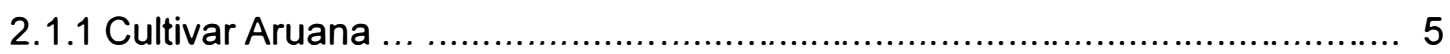

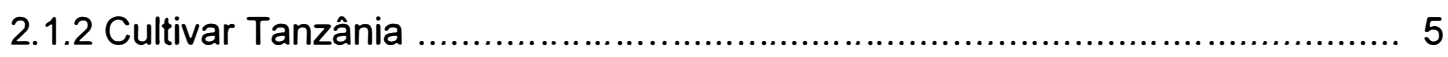

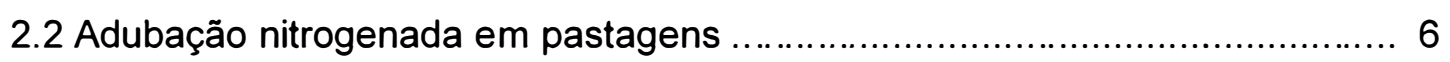

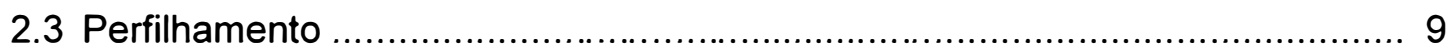

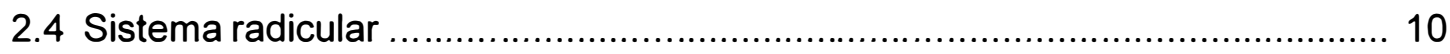

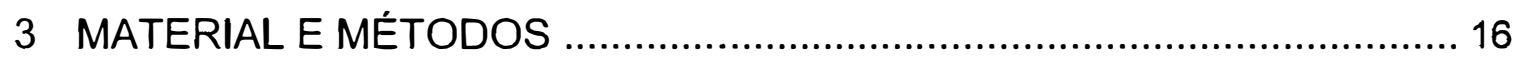

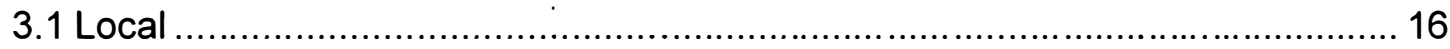

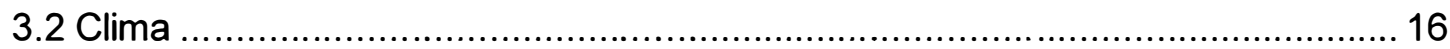

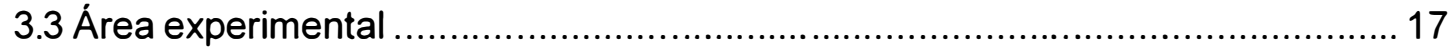

3.4 Delineamento experimental e tratamentos.................................................... 18

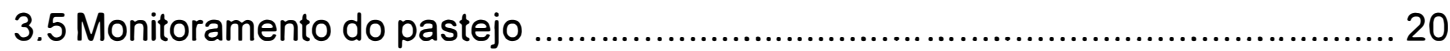

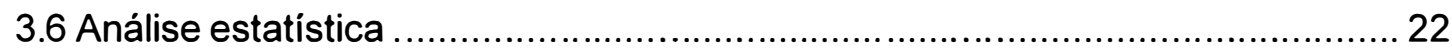

3.7 Amostragens e variáveis a serem avaliadas ......................................... 23

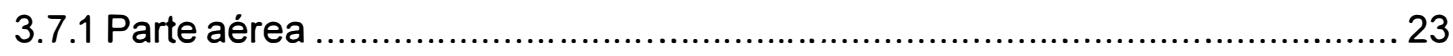

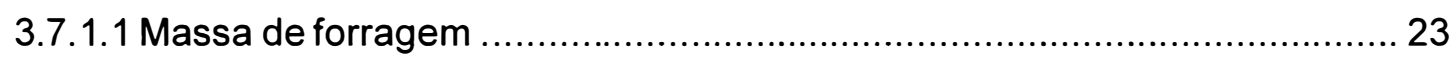

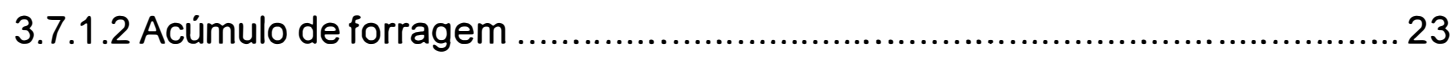

3.7.1.3 Separação dos componentes e número de perfilhos ................................ 23

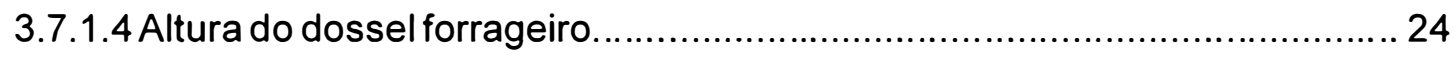

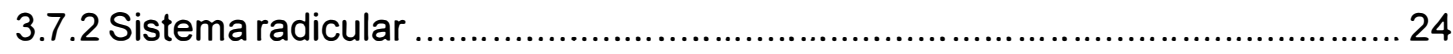

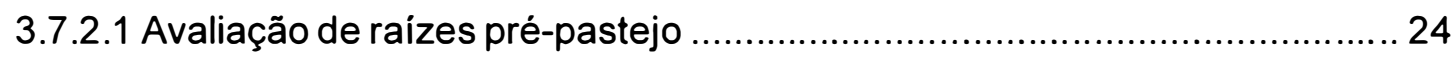


3.7.2.2 Crescimento do sistema radicular após o pastejo ............................... 25

3.7.2.3 Variáveis do sistema radicular ........................................................ 25

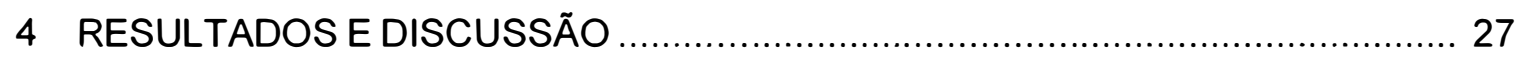

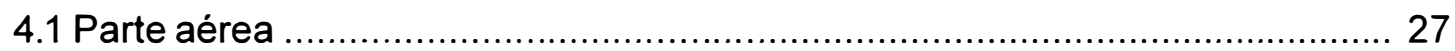

4.1.1 Massa de forragem e dos seus componentes .................................... 27

4.1.2 Acúmulo de forragem ................................................................... 31

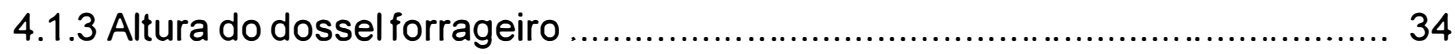

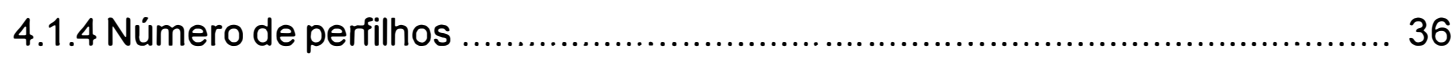

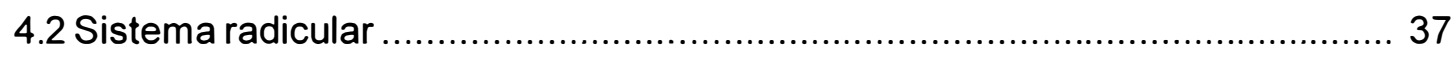

4.2.1 Massa, comprimento e superfície radiculares no pré-pastejo ................... 37

4.2.2 Crescimento do sistema radicular pós-pastejo .................................... 42

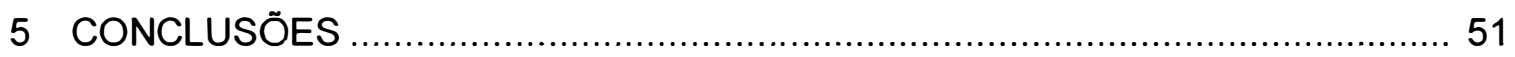

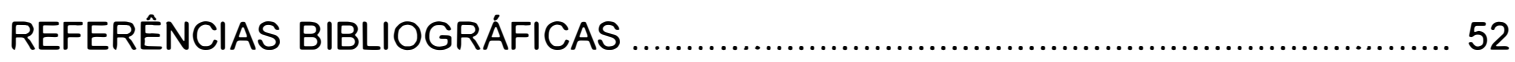

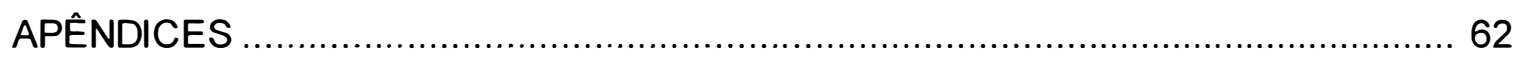




\title{
PRODUÇÃO DE FORRAGEM, MASSA E CRESCIMENTO DE RAÍZES DOS CAPINS ARUANA E TANZÂNIA SUBMETIDOS A DOSES DE NITROGÊNIO, EM LOTAÇÃO ROTACIONADA COM OVINOS.
}

\author{
Autora: ALESSANDRA APARECIDA GIACOMINI \\ Orientador: PROF. DR. HERBERT BARBOSA DE MATTOS
}

\section{RESUMO}

O presente estudo foi conduzido de 09/05/2002 a 25/04/2003 em uma área experimental pertencente ao Instituto de Zootecnia de Nova Odessa - SP, a $22^{\circ} 42^{\prime}$ de latitude Sul e $47^{\circ} 18^{\prime}$ de longitude Oeste e altitude média de $528 \mathrm{~m}$. Teve por objetivo estudar algumas caracteristicas de produção de forragem da parte aérea (massa de forragem e seus componentes, acúmulo de forragem, taxa de acúmulo de forragem $e$ densidade populacional de perfilhos) e do sistema radicular (massa, comprimento e superficie pré-pastejo, e crescimento pós-pastejo) dos capins Aruana e Tanzânia submetidos a doses de nitrogênio (150 e $300 \mathrm{~kg} \mathrm{ha}^{-1} \mathrm{de} \mathrm{N}$ ) e pastejados por ovinos em sistema de lotação rotacionada com três a sete dias de pastejo e período de descanso variável. O delineamento experimental foi de blocos completos casualizados (quatro) com duas repetições dentro de cada bloco, em esquema de parcelas subdivididas sendo o fator capim alocado nas parcelas e doses de $\mathrm{N}$ alocado nas subparcelas, com medidas repetidas no tempo. Ao longo do ano, foram analisados seis ciclos de pastejo para as variáveis da parte aérea, e quatro períodos de rebrotação para as variáveis do sistema radicular. Não existiu diferença em massa de forragem pré-pastejo para capins e doses de nitrogênio, que na média dos ciclos de pastejo foi de 4,19 e 4,73 $\mathrm{Mg} \mathrm{ha}^{-1}$ de MS ( $P>0,10)$ para os capins Aruana e Tanzânia, e de 4,20 e 4,71 $\mathrm{Mg} \mathrm{ha}^{-1}$ de MS $(P>0,10)$ para as doses de 150 e $300 \mathrm{~kg} \mathrm{ha}^{-1}$ de $\mathrm{N}$, respectivamente. O capimTanzânia apresentou maior quantidade $(P<0,10)$ de material morto $\left(1,3 \mathrm{Mg} \mathrm{ha}^{-1}\right.$ de 
MS) que o capim-Aruana (0,9 Mg ha-1 de MS) como média entre os ciclos de pastejo. A sistemática de adubação nitrogenada utilizada (1/3 no início das águas e os outros $2 / 3$ no final das águas) contribuiu para acúmulo de forragem no período seco correspondendo a aproximadamente $39 \%$ do total anual, embora sem efeito das doses de $\mathrm{N}$ e sem diferença entre capins. O capim-Aruana apresentou maior número $(P<0,10)$ de perfilhos $\left(1306 \mathrm{~m}^{-2}\right)$ que 0 capim-Tanzânia $\left(508 \mathrm{~m}^{-2}\right)$ devido ao perfilhamento aéreo. As variáveis massa, comprimento e superficie de raizes no prépastejo apresentaram comportamento semelhante entre si, sendo que houve efeito de estação do ano, com maior quantidade de raizes nos periodos referentes ao inverno e verão. $\mathrm{O}$ capim-Tanzânia, na média entre capins, doses de $\mathrm{N}$ e periodos de pastejo, apresentou maior quantidade de massa seca da matéria orgânica (MSMO) (1,7 mg $\mathrm{cm}^{-3}$ de solo) do que o capim-Aruana $\left(1,2 \mathrm{mg} \mathrm{cm}^{-3}\right.$ de solo) além de maior comprimento de raizes $\left(119,1 \mathrm{~cm} \mathrm{~cm}^{-3}\right.$ de solo) do que o capim-Aruana $\left(68,7 \mathrm{~cm} \mathrm{~cm}^{-3}\right.$ de solo). A dose de $300 \mathrm{~kg} \mathrm{ha}^{-1}$ de $\mathrm{N}$ contribuiu para maior comprimento do sistema radicular (107,1 $\mathrm{cm} \mathrm{cm}^{-3}$ de solo) do que a dose de $150 \mathrm{~kg} \mathrm{ha}^{-1}$ de $\mathrm{N}\left(80,7 \mathrm{~cm} \mathrm{~cm}^{-3}\right.$ de solo). $O$ crescimento radicular pós-pastejo, medido por meio de buracos cilindricos preenchidos com areia ("refilled cores"), mostrou similaridade de comportamento entre as variáveis mensuradas, de forma que o crescimento de raízes se tornou mais evidente após a segunda semana de rebrotação. Na média de capins, doses de $\mathrm{N}$ e idades de crescimento, no periodo equivalente ao outono o crescimento de raizes em MSMO foi de $3,9 \mathrm{mg} 125,6 \mathrm{~cm}^{-3}$, aumentou para $12,9 \mathrm{mg} 125,6 \mathrm{~cm}^{-3}$ no inverno, caiu para $4,7 \mathrm{mg}$ $125,6 \mathrm{~cm}^{-3}$ na transição entre inverno e primavera e aumentou novamente para $17 \mathrm{mg}$ $125,6 \mathrm{~cm}^{-3}$ no verão, com comportamento semelhante para as variáveis comprimento $\mathrm{e}$ superfície de raizes. A dose de $150 \mathrm{~kg} \mathrm{ha}^{-1}$ de $\mathrm{N}$ promoveu maior crescimento em comprimento e superficie de raizes do que a dose de $300 \mathrm{~kg} \mathrm{ha}^{-1} \mathrm{~N}$. 


\title{
FORAGE PRODUCTION, ROOT MAS AND GROWING FROM ARUANA AND TANZÂNIA GRASSES UNDER NITROGEN RATES, IN ROTATIONAL STOCKING WITH SHEEPS.
}

\author{
Author: ALESSANDRA APARECIDA GIACOMINI \\ Adviser: PROF. DR. HERBERT BARBOSA DE MATTOS
}

\section{SUMMARY}

The present study was carried out from 09/05/2002 to 25/04/2003 in a experimental area at Instituto de Zootecnia, Nova Odessa - SP, $22^{\circ} 42^{\prime} \mathrm{S}$ and $47^{\circ} 18 \mathrm{~W}$ and $528 \mathrm{~m}$ altitude. The objective was to evaluate some forage production characteristics from shoot (forage mass and its components, forage accumulation, forage accumulation rate and tiller population density) and root (pre-grazing root mass, lenght and surface, and post grazing growth) from Aruana and Tanzânia grasses under two nitrogen rates ( 150 and $300 \mathrm{~kg} \mathrm{ha}^{-1} \mathrm{~N}$ year) grazed by sheeps in rotacional grazing with three to seven grazing period and variable resting period. The experiment was a complete randomized block (four) design with two replicates within each block, with grasses as plots (paddock) and the nitrogen rates as sub-plots, with repeated measures. During the year, it was analysed six grazing periods for shoot measurements and four regrowth periods for root measurements. There was no difference in pregrazing forage mass due to grasses and nitrogen rates, with 4.19 and $4.73 \mathrm{Mg} \mathrm{ha}^{-1} \mathrm{MS}$ $(P>0.10)$ for Aruana and Tanzânia grasses, and 4.20 and $4.71 \mathrm{Mg} \mathrm{ha}^{-1} \mathrm{MS}(P>0.10)$ for 150 and $300 \mathrm{~kg} \mathrm{ha}^{-1} \mathrm{~N}$ nitrogen rates, respectively, averaged over the hole experiment. Tanzânia grass presented higher senescent material $(P<0.10)\left(1.3 \mathrm{Mg} \mathrm{ha}^{-1} \mathrm{MS}\right)$ than Aruana grass $\left(0.91 \mathrm{Mg} \mathrm{ha}^{-1} \mathrm{MS}\right)$ averaged within the grazing periods. The nitrogen fertilization strategy utilized (1/3 in the beggining of the rainny season and $2 / 3$ at the end), contributed to forage accumulation in the dry period corresponding to about $39 \%$ 
from the anual yield. However it was not observed $(P>0.10)$ effect of nitrogen rates and grasses. Aruana grass showed higher $(P<0.10)$ tiller number $\left(1306 \mathrm{~m}^{-2}\right)$ than Tanzânia grass $\left(508 \mathrm{~m}^{-2}\right)$, mainly due to aerial tillers. The pre-grazing root mass, length and surface showed similar behavior, and there was a seasonal effect, with higher root mass on Winter and Summer periods. Tanzânia grass, averaged within grasses, nitrogen rates and grazing period, showed higher amount of dry matter of organic matter (DMOM) $\left(1.7 \mathrm{mg} \mathrm{cm}^{-3}\right.$ of soil) than Aruana grass $\left(1.2 \mathrm{mg} \mathrm{cm}^{-3}\right.$ of soil) and greater root lenght $\left(119.1 \mathrm{~cm} \mathrm{~cm}^{-3}\right.$ of soil) than Aruana grass $\left(68.7 \mathrm{~cm} \mathrm{~cm}^{-3}\right.$ of soil). The $300 \mathrm{~kg} \mathrm{ha}^{-1} \mathrm{~N}$ nitrogen rate contributed to a higher root system lenght $\left(107.1 \mathrm{~cm} \mathrm{~cm}^{-3}\right.$ of soil) than the $150 \mathrm{~kg} \mathrm{ha}^{-1} \mathrm{~N}\left(80.7 \mathrm{~cm} \mathrm{~cm}^{-3}\right.$ of soil). The post-grazing root growth measured with cilindric refilled cores showed similar behaviour among the variables measured, being mor evident after the second regrowth week. Averaged within grasses, nitrogen rates and growth age, in the period equivalent to Autumm the DMOM growth root was $3.9 \mathrm{mg} 125.6 \mathrm{~cm}^{-3}$, increased to $12.9 \mathrm{mg} 125.6 \mathrm{~cm}^{-3}$ in Winter, decreased to $4.7 \mathrm{mg} 125.6 \mathrm{~cm}^{-3}$ between Winter and Spring, and raised to $17 \mathrm{mg} 125.6$ $\mathrm{cm}^{-3}$ on Summer, with similar behaviour to root lenght and surface. The $150 \mathrm{~kg} \mathrm{ha}^{-1} \mathrm{~N}$ nitrogen rate promoted higher lenght and surface than $300 \mathrm{~kg} \mathrm{ha}^{-1} \mathrm{~N}$ nitrogen rate. 


\section{INTRODUÇÃO}

A necessidade de maior atenção para com o manejo adequado da pastagem, incluindo a fertilidade do solo, visando assegurar sua longevidade e maior produtividade, tem recebido maior ênfase nos últimos anos. Embora o manejo da pastagem represente um dos principais meios para assegurar a sustentabilidade de sistemas de produção animal pastoris, ainda não se têm informações consistentes sobre o manejo das principais espécies forrageiras cultivadas no país (Martha Júnior \& Vilela, 2002), o que é o caso do capim-Tanzânia e, mais acentuadamente, do capimAruana.

Em razão da importância econômica da produção de ovinos em pastagens, medidas acertadas no manejo, incluindo a adubação, visando aumentar a sua produtividade e lucratividade, são de extrema relevância. Além disso, tem sido verificado crescente interesse de técnicos e produtores por sistemas intensivos de pastejo para ovinos, onde está embutida a necessidade de cuidados com o manejo do pastejo, manutenção e reposição da fertilidade do solo.

Atualmente o ovinocultor, por razões econômicas, tem apresentado maior interesse no uso intensivo de pastagens para alimentar seu rebanho. Contudo, 0 suprimento de forragem varia durante o ano em razão das diferentes taxas de acúmulo dos pastos (sazonalidade), o que dificulta o planejamento da produção animal em pastagens. Para a lotação rotacionada com ovinos, o uso de capins do gênero Panicum maximum Jacq. seria uma das alternativas, consequência de sua alta capacidade de produção de forragem por unidade de área e hábito de crescimento cespitoso. A utilização da lotação rotacionada em capins de hábito de crescimento cespitoso para ovinos, com rebaixamento acentuado da forragem $(15-20 \mathrm{~cm}$ de altura), é recomendada para reduzir a infestação da pastagem por larvas de helmintos. Com esse manejo baixo há redução significativa no número de larvas infestantes pela 
exposição à radiação ultravioleta, maior ventilação e temperatura elevada (Santos et al., 2001a).

Os ovinos realizam o pastejo de forma severa e baixa pois possuem o lábio superior fendido, o que garante grande mobilidade, permitindo uma desfolha baixa e seletiva, com maior remoção de folhas (Matches, 1992). Com o rebaixamento acentuado da pastagem, a recuperação da planta forrageira torna-se dependente dos pontos de crescimento e de outras regiões meristemáticas localizadas abaixo da altura de desfolha, das folhas remanescentes e das reservas orgânicas armazenadas na base do colmo e no sistema radicular (Herling et al., 2000). Dentro desse contexto, torna-se interessante o estudo de algumas características de produção de forragem e a dinâmica do sistema radicular das espécies forrageiras, monitorando as mudanças na produção de raízes induzidas por esse manejo diferenciado (altura do resíduo póspastejo baixa) e pela adubação nitrogenada.

Poucas são as informações na literatura sobre manejo do pastejo de variedades de Panicum maximum Jacq. para ovinos. No entanto, na Unidade de Ovinos e Caprinos do Instituto de Zootecnia de Nova Odessa, os capins Tanzânia e Aruana têm sido utilizados com bons resultados, como diminuição da incidência de verminoses e ganhos animais satisfatórios. Observou-se a manutenção da produtividade e persistência das plantas no dossel forrageiro (Santos et al., 2001a), que entretanto devem ser quantificadas e discutidas, sendo esse o propósito do presente trabalho.

A produtividade da parte aérea é o reflexo do que acontece com o sistema radicular, pois ambos interagem. Logo, qualquer fator que limite o desenvolvimento de raízes pode prejudicar a produção de massa seca da planta forrageira. O volume de informações sobre o desenvolvimento de raizes é pequeno, contrariamente àquelas disponiveis para a parte aérea. Se pouco ainda se conhece sobre os mecanismos de desenvolvimento do caule, muito menos se sabe sobre os da raiz (Matta, 1999). O conhecimento prévio do desenvolvimento e distribuição do sistema radicular pode orientar práticas que visem aumentar a perenidade e produtividade da pastagem no sistema de produção (Da Costa et al., 1983).

Diante do exposto, o objetivo deste experimento foi identificar períodos-chave de formação de raízes e a extensão em que isso pode oferecer oportunidade de manipulação de acordo com o manejo do pastejo e a adubação nitrogenada. Com essas informações, espera-se prevenir o comprometimento do sistema radicular, 
garantindo alta produção e persistência da pastagem, através do fornecimento de bases para maior entendimento do comportamento da planta forrageira no sistema de produção. 


\section{REVISÃO DE LITERATURA}

\subsection{Panicum maximum Jacq.}

Da familia Graminae, subfamília Panicoideae, tribo Paniceae, o gênero Panicum inclui várias plantas perenes ou anuais de diversos hábitos de crescimento. Possui mais de 500 espécies que ocorrem em paises de clima quente, principalmente nos trópicos do mundo inteiro (Bogdan, 1977). Dentro desse gênero há várias espécies utilizadas para pastejo, entretanto somente poucas são utilizadas para produção animal.

O Panicum maximum Jacq., amplamente utilizado, é originário da África tropical. Foi introduzido nas Américas provavelmente no fim do século dezoito, acidentalmente, com os navios de escravos vindos do Oeste da África. A partir daí se espalhou devido à sua alta produtividade, aceitabilidade e boa persistência (Jank, 1994). Os cultivares Tobiatã, Mombaça, Tanzânia e Aruana estão entre os mais conhecidos atualmente.

Este gênero caracteriza-se por possuir grande variabilidade genética e morfofisiológica. É constituído por espécies de hábito de crescimento ereto, estolonifero e rizomatoso, por plantas tolerantes e sensiveis ao encharcamento, por ecotipos que exigem solos com fertilidade moderada a alta e com reprodução apomítica e sexuada (sementes) (Corsi \& Nascimento Júnior, 1994).

A espécie Panicum maximum Jacq. apresenta estacionalidade de produção durante o ano. Jank et al. (1994), trabalhando com 156 acessos provenientes da África, encontraram aqueles que produziram até $24 \%$ da produção anual no "inverno", sendo que os acessos mais produtivos apresentaram maior estacionalidade de produção, variando de 5 a $13 \%$ no período das secas.

Nos últimos 20 anos, nove cultivares foram lançados como resultado de programas de seleção em diferentes instituições no Brasil: IZ-1 (1979), Tobiatã (1982), 
Centenário (1986), Centauro (1988), Aruana (1989), Vencedor, (1990), Tanzânia (1990), Mombaça (1993) (Jank, 1995) e Massai (Euclides et al., 2000).

\subsubsection{Cultivar Aruana}

Sementes do cultivar Aruana foram trazidas da África nos anos 70 e, após anos de avaliação, o cultivar foi oficialmente lançado em 1989 pelo IZ - Instituto de Zootecnia, sob o número IZ-5, como uma nova opção para formação de pastagens. É uma graminea cespitosa de porte médio (70 a $90 \mathrm{~cm}$ de altura). Suas folhas são estreitas, de cor verde escuro, com panículas e espiguetas das inflorescências pequenas. Esse cultivar apresenta um número de perfilhos superior ao capim-Colonião comum, principalmente no período de "inverno", com menor índice de área foliar. Comparado aos outros cultivares, apresenta boa cobertura do solo devido a seus colmos finos e flexiveis que, quando em contato com o solo, produzem raizes. Produz 15 a 20 ton ha ${ }^{-1}$ ano $^{-1}$ de MS, com $35 \%$ de sua produção anual concentrada durante o período de "inverno" (Instituto de Zootecnia, 1989). Já Cecato et al. (1994) afirmam que o capim-Aruana tem se destacado por apresentar uma melhor distribuição anual de produção de forragem, com $27 \%$ da produção total anual durante o período crítico do ano.

O capim-Aruana tem alta persistência sob pastejo severo e rápida rebrotação após desfolhação, que está atribuida às suas numerosas gemas basais. Possui alta aceitabilidade por ovelhas e tem sido utilizado com sucesso desde 1995 em sistemas de pastejo para ovinos (Santos et al., 2001b).

\subsubsection{Cultivar Tanzânia}

O cultivar Tanzânia é originário da África e foi lançado no Brasil em 1990 pelo Centro Nacional de Pesquisa de Gado de Corte (CNPGC) da EMBRAPA, após estudos de competição com outros cultivares. Trata-se de uma graminea cespitosa com altura média de 1,3 $\mathrm{m}$ e folhas decumbentes com largura média de 2,6 cm. Os colmos são levemente arroxeados, as lâminas e bainhas não possuem pilosidade ou cerosidade. As inflorescências são do tipo panícula, com ramificações primárias longas, e secundárias longas apenas na base. As espiguetas são arroxeadas e uniformemente 
distribuidas (Jank \& Costa, 1990; Savidan et al., 1990). O potencial de utilização deste capim pode ser verificado por meio dos resultados obtidos durante a avaliação dos acessos no banco de germoplasma da EMBRAPA Gado de Corte. O capim-Tanzânia produziu 33 ton ha- ano $^{-1}$ de MS total, sendo 26 ton ha- ano ${ }^{-1}$ de MS foliar (80\%), com $12,7 \%$ de proteína bruta em média nas folhas e $9 \%$ nos colmos (Jank et al., 1994).

Em experimento conduzido por Cecato et al. (1996) com cortes $(20$ e $40 \mathrm{~cm}$ de altura) realizados a cada 35 dias no "verão" (3 cortes) e 70 dias no "inverno" (2 cortes), a produção de massa seca total do capim-Tanzânia no "verão" foi de $7.441 \mathrm{~kg} \mathrm{ha}^{-1}$ e no "inverno" de $2.711 \mathrm{~kg} \mathrm{ha-1}$, mostrando sua acentuada estacionalidade de produção, mas sem alteração na produtividade com a altura de corte.

Maior produção de forragem em capim-Tanzânia resultante da adubação nitrogenada tem sido relatada por diversos autores (Forni et al., 2000; Queiroz Neto et al., 2001).

\subsection{Adubação nitrogenada em pastagens}

Uma técnica importante no manejo de pastagens que tem provocado aumento na produtividade e melhora no desempenho econômico de sistemas de produção pastoris é o uso de fertilizantes nitrogenados. $\dot{E}$ evidente, nos dias atuais, a necessidade de desenvolver estratégias para assegurar a nutrição adequada da planta forrageira e do animal em pastejo ao mesmo tempo em que se confere proteção aos recursos naturais e qualidade do solo, água e atmosfera (Jarvis, 1998).

Os efeitos do nitrogênio sobre as plantas em geral já foram muito estudados e são bem conhecidos, mas por outro lado são de difícil previsão, pois dependem das condições de absorção, as quais dependem do tamanho do sistema radicular, e, sobretudo, da quantidade de $\mathrm{N}$ disponivel no solo (tipo de solo, teor de matéria orgânica, culturas precedentes), da taxa de mineralização da matéria orgânica do solo (temperatura, teor de umidade, grau de compactação) e da quantidade, tipo e forma de aplicação do fertilizante nitrogenado utilizado. Além do mais, depende também das condições de crescimento da planta, determinadas primariamente pela quantidade de radiação incidente que é interceptada, temperatura e disponibilidade hídrica (Nabinger \& Medeiros, 1995). A interação com os efeitos da temperatura e da disponibilidade 
hídrica modificam as respostas à aplicação de fertilizantes nitrogenados (Gastal et al., 1992).

Desse modo, é fato conhecido que a adubação nitrogenada tem efeito marcante sobre a produção de plantas forrageiras. Em gramineas tropicais, a resposta ao nitrogênio pode se dar até em doses bem elevadas desse elemento (Zimmer, 1999). O nitrogênio é um dos nutrientes absorvidos em maiores quantidades pelas plantas forrageiras, dai sua alta exigência. Além disso, é o nutriente mais importante em termos de quantidade para maximizar a produção de forragem em gramíneas forrageiras (Werner et al., 2001). Em plantas forrageiras já estabelecidas, o nitrogênio constitui-se no principal fator responsável pelo aumento imediato e visivel de produção, desde que fatores edáficos, climáticos e outros não sejam limitantes (Monteiro, 1995).

O nutriente mais limitante para a maioria das espécies forrageiras é 0 nitrogênio. A aquisição e assimilação de nitrogênio só perde em importância para a assimilação de carbono via fotossíntese para crescimento e desenvolvimento da planta. Produção de forragem de alta qualidade e rica em proteína é extremamente dependente da disponibilidade de nitrogênio (Mazzanti et al., 1994).

Há uma correlação estreita entre absorção de nitrogênio e crescimento. Sob condições estáveis de ambiente e suprimento de nutrientes, o crescimento é modulado até se alcançar a condição onde novo material é formado numa taxa equivalente à do nitrogênio que é retirado pela planta (Mattsson et al., 1991). A implicação é que a taxa de absorção do nitrogênio é regulada continuamente de acordo com o "status" desse elemento na planta.

A essencialidade do $\mathrm{N}$ para a produtividade da planta forrageira reflete sua influência sobre aspectos morfofisiológicos em razão da participação desse elemento, por exemplo, na estrutura de proteínas, da clorofila e de carreadores que participam de processos fisiológicos no vegetal. Para Panicum maximum tem sido bem caracterizado que $\mathrm{o}$ aumento na disponibilidade de $\mathbf{N}$ no meio interfere positivamente sobre os fatores que estimulam 0 crescimento acelerado da planta forrageira $e$, consequentemente, concorrem para o aumento da produtividade da pastagem, como a mobilização de reservas ( $\mathrm{C}$ e N) na planta depois da desfolhação, a expansão da área foliar e o aumento no peso e no número de perfilhos (Mello, 2002; Santos, 2002).

Outro fator importante é que em situações de desfolhação intensa, as plantas não possuem área foliar residual capaz de fixar carbono via fotossintese em 
quantidades suficientes para sustentar sua demanda fisiológica. Nessas condições, a planta forrageira fica dependente de suas reservas fisiológicas até que um mínimo de área foliar, capaz de suprir suas exigências energéticas (fotossintese), seja reconstituida (Lemaire, 1997).

Nesse contexto, as reservas de compostos nitrogenados são as mais importantes para o restabelecimento da rebrotação pós-desfolhação. A remobilização desses compostos é mais intensa a partir do resíduo pós-pastejo (principalmente da base do colmo de espécies de hábito de crescimento cespitoso) e, em seguida, do sistema radicular. Essas reservas são importantes para assegurarem a reconstituição do aparato fotossintético (enzimas como carboxilases, elongação de folhas e, posteriormente, aumento da área foliar através do perfilhamento) (Corsi et al., 2001). Estudos mais recentes (Lemaire \& Chapman, 1996; Lemaire, 1997; Martha Júnior, 1999; Louahlia et al., 2000) têm dado suporte à idéia de que a reserva nitrogenada da planta forrageira seria o fator fundamental para a pronta recuperação da planta após o corte ou pastejo. Até $80 \%$ do nitrogênio presente na parte aérea formada na primeira semana após o corte pode ser proveniente da translocação a partir de raízes e hastes, sendo o restante proveniente da absorção via solo (Lemaire \& Chapman, 1996). Porém, o padrão de remobilização dessas reservas nitrogenadas até o novo tecido está associado à quantidade de nitrogênio presente no sistema solo-planta (Corsi et al., 2001).

Dentre os aspectos desejáveis à utilização de plantas forrageiras, a distribuição uniforme da produção de forragem ao longo do ano pode ser considerada como um dos atributos mais atraentes e cobiçados pelos produtores. A estacionalidade de produção de forragem determina a flutuação na alimentação de ruminantes baseada na produção das pastagens, resultando nos ciclos característicos de safra e entressafra da produção pecuária nacional (Gomide, 1990). A estacionalidade de produção de forragens no Brasil é devida, principalmente, à não ocorrência de chuvas durante algumas épocas do ano, o que limita o crescimento das plantas forrageiras nesses períodos. Com isso, alternam-se períodos de crescimento vigoroso e altas produções em épocas quentes e úmidas (águas), com periodos de pouco crescimento e baixa produção em épocas frias e secas (seca). Segundo Rodrigues \& Rodrigues (1987), o periodo relativo ao "inverno" (seca) é compreendido entre os meses de junho 
a outubro. Para distribuição mais uniforme da produção de forragem ao longo do ano, pode-se utilizar algumas técnicas, dentre elas a estratégia da adubação nitrogenada.

Trabalhando com capim-Colonião, Werner (1970/71) estudou épocas de adubação nitrogenada na busca de maior suprimento de forragem para a época seca do ano. Utilizou nitrocálcio para fornecer o nutriente à base de $100 \mathrm{~kg} \mathrm{ha}^{-1}$ ano-1, testando nove épocas de aplicação. Com base em resultados de três anos, quando considerou a proporção da produção de forragem no periodo da seca em relação ao total anual, obteve $21 \%$ quando $2 / 3$ do total de $\mathrm{N}$ foi aplicado em março de cada ano, em contraposição aos 7,6 a 9,0\% verificados para as adubações de novembro e janeiro, respectivamente, melhorando a distribuição da produção entre "verão" e "inverno", diminuindo a estacionalidade de produção de forragem.

Em experimento de campo realizado em solo Podzólico Vermelho - Amarelo variação Laras, Mattos \& Werner (1979) estudaram por um periodo de três anos a resposta do capim-Colonião ao nitrogênio, nas doses de $0,75,150$ e $220 \mathrm{~kg} \mathrm{ha}^{-1} \mathrm{de} \mathrm{N}$, sendo um terço aplicado no início e dois terços no final das águas. Observaram que a produção de forragem aumentou linearmente com a elevação das doses de nitrogênio.

O uso de adubação nitrogenada, estimulando o crescimento das plantas, pode elevar as perdas de forragem se a colheita (animal ou mecânica) não for eficiente. $A$ produção intensiva de forragem ainda pode provocar na planta maior exigência de outros nutrientes, no tempo e em quantidade, devido às maiores exportações de nutrientes das áreas de pastagens na forma de produto animal (Corsi, 1994).

\subsection{Perfilhamento}

A unidade básica de produção das gramineas forrageiras é o perfilho. O estudo dos componentes do relvado, como o número de perfilhos, pode auxiliar no entendimento das respostas das plantas forrageiras ao pastejo. A produção de novos perfilhos é normalmente um processo contínuo que pode ser alterado pela intensidade de desfolhação das plantas e, consequentemente, melhoria da iluminação na base do dossel forrageiro. (Hodgson, 1990).

A produção de massa por área e a estrutura do dossel forrageiro são dependentes da densidade populacional de perfilhos na pastagem (Nabinger, 2002). Segundo Langer (1979), vários são os fatores que afetam o perfilhamento de plantas 
forrageiras. A produção de perfilhos é influenciada pela disponibilidade de água, luz, temperatura, nutrientes (principalmente nitrogênio) e estádio de desenvolvimento da planta (reprodutivo ou vegetativo).

Em pastos de gramíneas ocorre um mecanismo de renovação, segundo o qual os perfilhos mais velhos morrem à medida que novos perfilhos vão sendo produzidos. Nessa situação, assume-se que quando uma determinada densidade populacional de perfilhos é atingida, as populações de perfilhos flutuam ao redor de um determinado valor base. Haveria, portanto, um mecanismo de auto-restrição cuja severidade parece ser proporcional à densidade populacional de perfilhos (Da Silva \& Pedreira, 1997).

Em pastagens mantidas sob lotação contínua, a densidade populacional de perfilhos é determinada principalmente pelo indice de área foliar (IAF) no qual o pasto é mantido, e pastos mantidos em regime de desfolhação intensa têm densidade populacional de perfilhos maior que pastos mantidos em regime de desfolhação mais leniente (Grant et al., 1988). A densidade populacional de perfilhos é o componente do IAF que permite a maior flexibilidade de ajuste por parte da planta a diferentes regimes de desfolhação, razão pela qual o IAF é otimizado em pastos mantidos baixos pela alta densidade populacional de perfilhos pequenos (Da Silva, 2002).

Todo perfilho pode ser considerado como uma planta individual com seu próprio sistema radicular, mesmo que a conexão entre perfilhos "mãe e filho" ainda seja funcional. Dessa forma, massa de raizes e densidade populacional de perfilhos estão correlacionados. Quando o perfilho é desfolhado, a planta tenta restaurar a parte aérea e cessa o crescimento de raízes até que o equilíbrio original entre parte aérea e sistema radicular seja restaurado. Isso indica que em desfolhações drásticas e periódicas ocorrendo sob lotação rotacionada, a massa de raízes permanece baixa. Quanto mais frequentes as desfolhações e menor a altura do residuo pós-pastejo, menor a massa de raizes. O crescimento de raizes é reduzido quando os perfilhos estão na fase reprodutiva (Deinum, 1985).

\subsection{Sistema radicular}

Ao descrever e estudar uma planta, é norma geral subdividi-la em uma parte acima da superfície do solo, denominada parte aérea, e outra abaixo da superfície do solo, denominada sistema radicular. São funções primárias da parte aérea a captação 
de luz solar e a troca de gases com a atmosfera. O sistema radicular tem como funções permitir a absorção de água e nutrientes, servindo também para fixar a planta no solo (Libardi \& Lier, 1999).

Entretanto, há falta de informações disponiveis sobre a produção de massa e morfologia do sistema radicular de plantas forrageiras (Bono et al., 2000). O ecossistema de pastagens é dinâmico, apresenta a distribuição de sua produção anual entre as partes aérea e subterrânea, mas pode sofrer alterações decorrentes das variações das condições de meio ambiente. Num sistema de pastejo, a parte aérea é mais valorizada porque vai ser consumida, mas a planta deve ser estudada como um todo. Embora não sejam consumidas diretamente, as raízes devem ser consideradas devido à sua capacidade de armazenar carboidratos e proteinas, o que influencia diretamente na rebrotação após desfolhação. O pastejo afeta diretamente 0 desenvolvimento do sistema radicular, influindo na capacidade das plantas forrageiras de resistir a períodos de estresse hídrico e competir por nutrientes no solo (Herling et al., 2001).

Desse modo, o primeiro efeito imediato da desfolhação sobre a planta é a redução de sua área foliar, e consequentemente, de sua capacidade em interceptar luz (Lemaire, 2001). À medida que a desfolhação se torna mais severa, a proporção de tecido remanescente é reduzida, podendo tornar-se muito baixa para assegurar um suprimento mínimo de carbono para a planta. Assim, depois de uma desfolhação severa, o suprimento de carbono para a planta torna-se tão baixo que seu balanço fica temporariamente negativo, até que uma área foliar suficiente, com alta capacidade fotossintética, seja novamente reconstituída. Após desfolhação, ocorre rápido declínio na quantidade de carboidratos solúveis nas raízes, resultado principalmente da redução na taxa fotossintética como um todo e da alocação preferencial de carbono para as partes aéreas da planta com a finalidade de restaurar sua área foliar. Segundo Richards (1993), estudos com plantas C3 e C4 têm mostrado que o crescimento de raizes cessa após a remoção de cerca de $50 \%$ ou mais de sua área foliar. Portanto, é inevitável a perda de parte do sistema radicular imediatamente após a desfolhação, proporcionalmente à frequência de corte ou pastejo. Por outro lado, essa redução na massa radicular imediatamente após a desfolhação parece ser uma estratégia fisiológica da planta forrageira, que busca proporcionar rápida recuperação da parte aérea (rápida retomada do processo fotossintético) e consequente equilibrio positivo de 
carbono na planta por meio da diminuição da demanda de carbono pelo sistema radicular (Richards, 1993). Contudo, essa perda de raízes também implica em menor capacidade de absorção de água e nutrientes pela planta forrageira.

Segundo Bloom (1994), outro fator de influência é que a ineficiência na absorção do $\mathrm{N}$ do solo deve-se mais à ausência de raizes no lugar certo e no momento apropriado do que a mecanismos inadequados de absorção do nutriente pela planta. As plantas parecem apresentar capacidade de absorver quantidade suficiente de $\mathrm{N}$ para atender as suas exigências desde que suas raizes estejam presentes em nichos onde o $\mathrm{N}$ se encontre em formas e/ou disponibilidades adequadas às características do sistema radicular (comprimento específico, por exemplo) (Gregory, 1994).

A absorção de água e nutrientes depende do crescimento contínuo do sistema radicular, uma vez que a principal área de absorção corresponde às regiões recémformadas ou mais jovens das raízes (Hopkins, 1995). Altas taxas de aplicação de $N$ reduziram o crescimento e a profundidade do sistema radicular em trigo (Comfort et al., 1988, citados por Baligar et al., 1998). Baligar et al. (1998) afirmaram que a deficiência de $\mathrm{N}$ aumentou o comprimento e a densidade dos pêlos radiculares.

Outro fator importante é que nutrientes e água são geralmente distribuídos irregularmente no solo. A habilidade das plantas em explorar o solo é uma função do comprimento, área, diâmetro e arranjo espacial de suas raízes que, coletivamente, determinam o volume de solo ocupado pelo sistema radicular. Há várias indicações de que espécies com alto comprimento especifico de raizes (comprimento / peso) tendem a ter maior plasticidade de crescimento de raizes e maior capacidade de absorção de água e nutrientes (Wright et al., 1999).

A disponibilidade de água no solo afeta a taxa de elongação das raízes e a absorção dos nutrientes pelas mesmas (Singh, 1998). Os atributos do solo que afetam a extensão e morfologia do crescimento do sistema radicular incluem quantidade de água, impedimento mecânico, regime térmico e desenvolvimento estrutural. $A$ extensão e função do sistema radicular, por sua vez, direta ou indiretamente, modifica essas condições do solo (Wraith \& Wright, 1998).

De acordo com Voorhees et al. (1980), a massa seca de raizes é um atributo fácil de ser obtido em relação a resultados de comprimento do sistema radicular, mas que somente a massa seca de raizes não expressa a extensão em que um dado volume de solo é explorado pelo sistema radicular e, consequentemente, não pode 
avaliar de forma consistente os processos de absorção de água e nutrientes. Nesse sentido, o comprimento das raízes pode ser uma variável importante para o estudo de crescimento da planta, contribuindo para gerar informações relacionadas à fisiologia e estado nutricional do vegetal.

À medida que a parte aérea das plantas é utilizada via pastejo, há decréscimo na fotossintese que, por sua vez, reduz a absorção de nutrientes pelas raizes, prejudicando o desenvolvimento de novos perfilhos no sentido de beneficiar a recuperação da área foliar remanescente após a desfolhação (Donaghy \& Fulkerson, 1998). Essa redução na fotossíntese logo após a desfolhação é devida principalmente à remoção de folhas mais jovens e eficientes no processo de fotossintese, localizadas no topo do relvado, ficando o processo fotossintético dependente das folhas velhas (porção inferior da cobertura vegetal), de menor atividade fotossintética. Fisiologicamente, as plantas forrageiras desfolhadas se utilizam dos carboidratos solúveis de reserva para a respiração e início da restauração de sua parte aérea. Em condições de baixos valores de carboidratos de reserva, o sistema radicular é reduzido drasticamente para atender a alocação preferencial dos metabólitos para a parte aérea. As reservas de compostos nitrogenados são importantes para reconstituírem o aparato fotossintético (enzimas, elongação de folhas) e, posteriormente, aumento da área foliar através do perfilhamento das plantas (Corsi et al., 2001).

A planta absorve o carbono do ar através da fotossíntese, e nitrogênio do solo por meio de seu sistema radicular. É a combinação desses dois componentes que dará origem aos novos tecidos da planta via processo de fotossintese. Quando o aporte de fotoassimilados é suficientemente grande para suplementar as necessidades dos tecidos meristemáticos, o crescimento (principalmente de folhas) pode atingir 0 potencial determinado pela temperatura e condições de ambiente. O excesso de assimilados pode ser armazenado em órgãos de reserva (raízes) para que sejam utilizados pelas plantas quando necessário (Lemaire \& Chapman, 1996).

Nesse contexto, a importância das reservas orgânicas para o vigor da rebrotação após a desfolhação por corte ou pastejo tem sido um dos tópicos mais controversos da agronomia das pastagens (Da Silva \& Pedreira, 1997). Os produtos da fotossintese translocados para o interior do solo são representados pelo tecido radicular vivo, exsudatos e diversos constituintes orgânicos derivados de raízes em 
crescimento, raízes mortas e pêlos radiculares, microrganismos rizosféricos e seus subprodutos (Mielniczuc, 1999).

Outra característica importante é a extensão do sistema radicular, que é resultado do potencial genético que a planta possui para desenvolver raízes (alocando uma parte de sua produção em carboidratos para o sistema radicular) e de fatores ambientais. Fatores externos que influenciam o desenvolvimento radicular podem ser classificados como quimicos $(\mathrm{pH}$, elementos tóxicos, nutrientes), físicos (oxigenação, temperatura, umidade, densidade, porosidade, fatores de manejo) e biológicos (atividade microbiana, entre outros). Quase todos esses fatores são interdependentes (Lemaire, 2001).

A redução do desenvolvimento do sistema radicular tem como consequências diminuições significativas da absorção de água e nutrientes das camadas subsuperficiais do solo, tornando as plantas mais susceptiveis à deficiência hídrica e nutricional durante a ocorrência de periodos de estiagem (Carvalho, 1999).

É importante ressaltar que grande concentração de raizes na camada superficial do solo, especialmente na camada de 0 a $5 \mathrm{~cm}$, ocorre com gramíneas forrageiras (Anghinoni \& Meures, 1999). A maior massa de raizes de gramíneas está concentrada perto da superfície do solo, com aproximadamente $80 \%$ do total nos primeiros $15 \mathrm{~cm}$ de profundidade (Gibbs, 1986; Barker et al., 1988; Brasil et al., 2000). Outros trabalhos relatam que a camada de $0-20 \mathrm{~cm}$ de solo seria a responsável pela maior proporção do volume radicular de gramineas (Carvalho, 1999; Matthew, 1992; Bono et al., 2000). A dificuldade de coleta em maiores profundidades pode ser fator limitante para a maior parte dos estudos com raizes (Pagotto, 2001), pois a partir dos $20 \mathrm{~cm}$ de profundidade a amostragem se torna difícil e trabalhosa. A amostragem de raízes na camada de 0-20 cm, por ser mais fácil de realizar, dispende menor tempo, e com isso pode-se aumentar o número de amostras coletadas, buscando diminuir a variabilidade dos dados que é excessivamente alta para estudos com raizes (Vogt \& Bloomfield, 1991; Pagotto, 2001). Segundo Deinum (1985), a variação na medida de massa seca de raizes é normalmente grande, variando entre 20 a 50\%.

Matthew \& Kemball (1997), em estudo com carbono radioativo, mostraram menor atividade do sistema radicular com a profundidade, observando maior desenvolvimento de massa e comprimento radiculares para as ramificações do eixo 
principal mais próximas à superficie do solo como resultado da maior alocação de carbono para essas regiões do sistema radicular.

Apesar da importância da caracterização do sistema radicular e de sua dinâmica em estudos com plantas forrageiras, Scurlock \& Hall (1998) estimaram que menos de $10 \%$ dos experimentos com pastagens consideraram avaliações do sistema radicular.

Com base no exposto, pode-se verificar a importância do estudo de raizes concomitantemente com a parte aérea, pois ambas funcionam integradamente e são responsáveis pela produção e perenidade da pastagem, juntamente com fatores ligados ao manejo do pastejo, adubação nitrogenada, solo e clima. 


\section{MATERIAL E MÉTODOS}

\subsection{Local}

O experimento foi desenvolvido em uma área experimental pertencente ao Instituto de Zootecnia, Nova Odessa - SP, com as seguintes coordenadas geográficas aproximadas: $22^{\circ} 42^{\prime}$ latitude Sul, $47^{\circ} 18^{\prime}$ longitude Oeste e $528 \mathrm{~m}$. O periodo experimental foi de 09/05/2002 a 25/04/2003.

\subsection{Clima}

A precipitação pluvial média anual do municipio é de $1270 \mathrm{~mm}$, sendo que apenas $30 \%$ dessa precipitação ocorre no periodo de maio a setembro. Os dados climáticos referentes ao periodo experimental (mai/2002 a abr/2003) foram coletados no posto meteorológico do Instituto de Zootecnia, Nova Odessa/SP (Figura 1). 


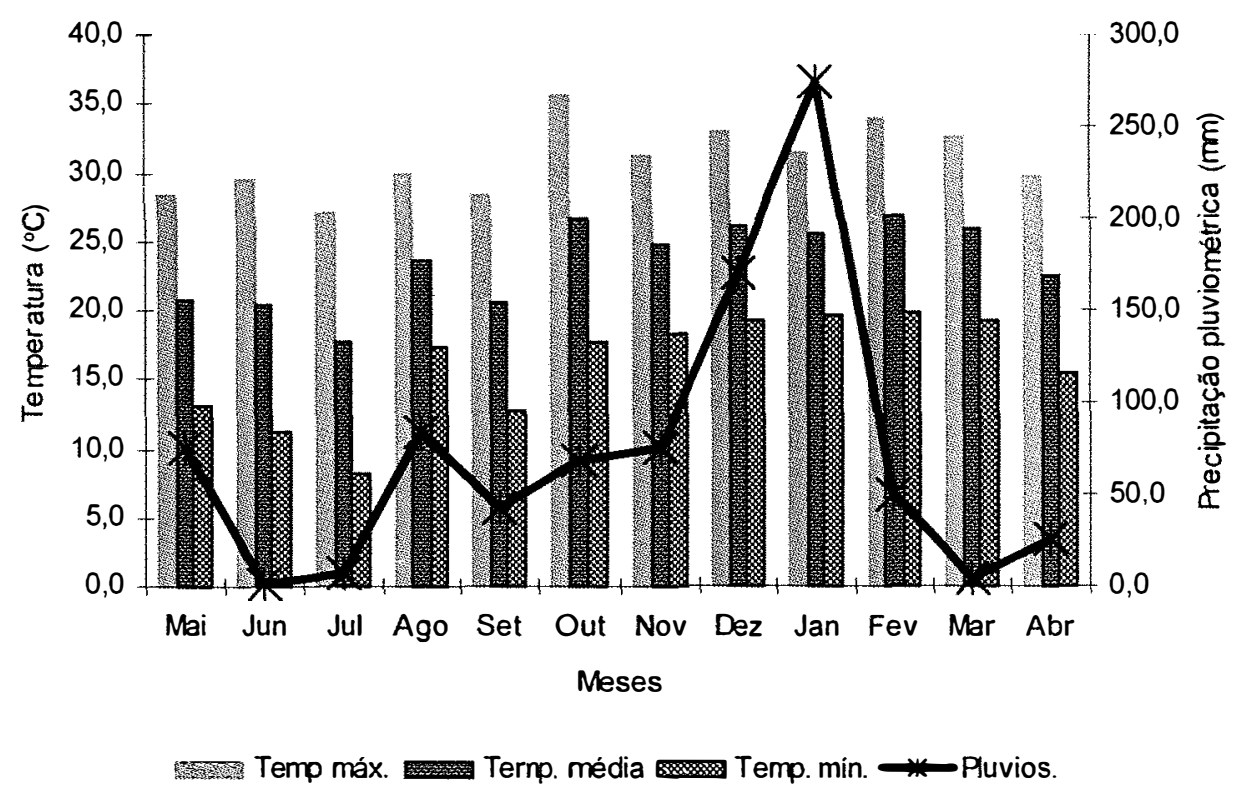

Figura 1 - Temperaturas máxima, mínima, média $\left({ }^{\circ} \mathrm{C}\right)$ e precipitação pluvial $(\mathrm{mm})$ durante o periodo experimental

\section{3 Área experimental}

A área experimental, situada num solo classificado como Argissolo Amarelo (Empresa Brasileira de Pesquisa Agropecuária, 1999), foi constituída de oito piquetes com aproximadamente $1500 \mathrm{~m}^{2}$ cada, estabelecidos em Dezembro de 2000, sendo quatro com capim-Aruana (Panicum maximum Jacq. cv. Aruana) e quatro com capimTanzânia (Panicum maximum Jacq. cv. Tanzânia), perfazendo quatro blocos experimentais. De acordo com os resultados das análises químicas do solo antes do início do experimento (Tabelas 1 e 2), não houve necessidade de calagem ou aplicação de outros nutrientes em relação às exigências das espécies em estudo (Raij et al., 1996). Por esse motivo, não foi realizada prática alguma de correção do solo antes do período de experimentação. 
Tabela 1. Resultado da análise do solo dos piquetes com o capim-Aruana

\begin{tabular}{ccccccccccc}
\hline Blocos & $\begin{array}{c}\mathrm{pH} \\
\left(\mathrm{CaCl}_{2}\right)\end{array}$ & $\begin{array}{c}\mathrm{M} . \mathrm{O}^{3} \\
\mathrm{~g} / \mathrm{dm}^{3}\end{array}$ & $\begin{array}{c}\mathrm{P} \\
\mathrm{mg} / \mathrm{dm}^{3}\end{array}$ & $\mathrm{~K}$ & $\mathrm{Ca}$ & $\begin{array}{c}\mathrm{Mg} \\
\mathrm{mmol} / \mathrm{dm}^{3}\end{array}$ & $\begin{array}{c}\mathrm{H}+\mathrm{Al} \\
\mathrm{S}\end{array}$ & $\mathrm{T}$ & $\begin{array}{c}\mathrm{V} \\
\%\end{array}$ \\
\hline $\mathrm{A}$ & 6,3 & 25 & 40 & 3,7 & 49 & 23 & 10 & 75,7 & 85,9 & 88 \\
$\mathrm{~B}$ & 6,3 & 16 & 23 & 1,6 & 30 & 13 & 12 & 44,8 & 56,8 & 79 \\
$\mathrm{C}$ & 5,5 & 43 & 20 & 2,7 & 41 & 19 & 11 & 62,7 & 73,5 & 85 \\
$\mathrm{D}$ & 5,5 & 41 & 21 & 3,2 & 43 & 13 & 18 & 67,0 & 85,2 & 79 \\
\hline
\end{tabular}

Tabela 2. Resultado da análise de solo dos piquetes com o capim-Tanzânia

\begin{tabular}{|c|c|c|c|c|c|c|c|c|c|c|}
\hline Blocos & $\underset{\left(\mathrm{CaCl}_{2}\right)}{\mathrm{pH}}$ & $\begin{array}{l}\mathrm{M} . \mathrm{O}^{3} \\
\mathrm{~g} / \mathrm{dm}^{3}\end{array}$ & $\underset{\mathrm{mg} / \mathrm{dm}^{3}}{\mathrm{P}}$ & $\mathrm{K}$ & $\mathrm{Ca}$ & $\underset{\mathrm{mm}}{\mathrm{Mg}}$ & $\begin{array}{l}\mathrm{H}+\mathrm{Al} \\
/ \mathrm{dm}^{3}\end{array}$ & $S$ & $T$ & $\begin{array}{l}\mathrm{V} \\
\%\end{array}$ \\
\hline$A$ & 6,4 & 16 & 42 & 2,4 & 33 & 17 & 11 & 52,7 & 63,4 & 83 \\
\hline$B$ & 6,5 & 24 & 25 & 2,2 & 27 & 15 & 12 & 44,2 & 56,2 & 79 \\
\hline C & 5,6 & 41 & 20 & 2,9 & 43 & 13 & 16 & 58,9 & 75,3 & 78 \\
\hline D & 5,9 & 54 & 20 & 6,1 & 70 & 19 & 17 & 95,5 & 112,8 & 85 \\
\hline
\end{tabular}

\subsection{Delineamento experimental e tratamentos}

O delineamento experimental para análise das variáveis da parte aérea e do sistema radicular foi de blocos completos casualizados (em número de quatro) com duas repetições dentro de cada bloco, em esquema de parcelas subdivididas sendo o fator capim alocado nas parcelas e doses de $\mathrm{N}$ alocado nas subparcelas, com medidas repetidas no tempo. Foram analisados seis ciclos de pastejo para as variáveis da parte aérea, e quatro periodos de rebrotação para as variáveis do sistema radicular.

Em cada bloco, o piquete de cada capim foi dividido ao meio, com cerca elétrica, com o objetivo de aumentar o número de parcelas experimentais. Cada parcela (metade do piquete) foi considerada como uma repetição dentro do bloco (Figura 2). As oito parcelas de cada capim, assim obtidas, foram pastejadas sequencialmente em sistema rotacionado de três a sete dias de pastejo (com o objetivo de atingir $20 \mathrm{~cm}$ de altura do residuo pós-pastejo em ambos os capins) e periodo de descanso variável, por dois lotes de ovinos. 


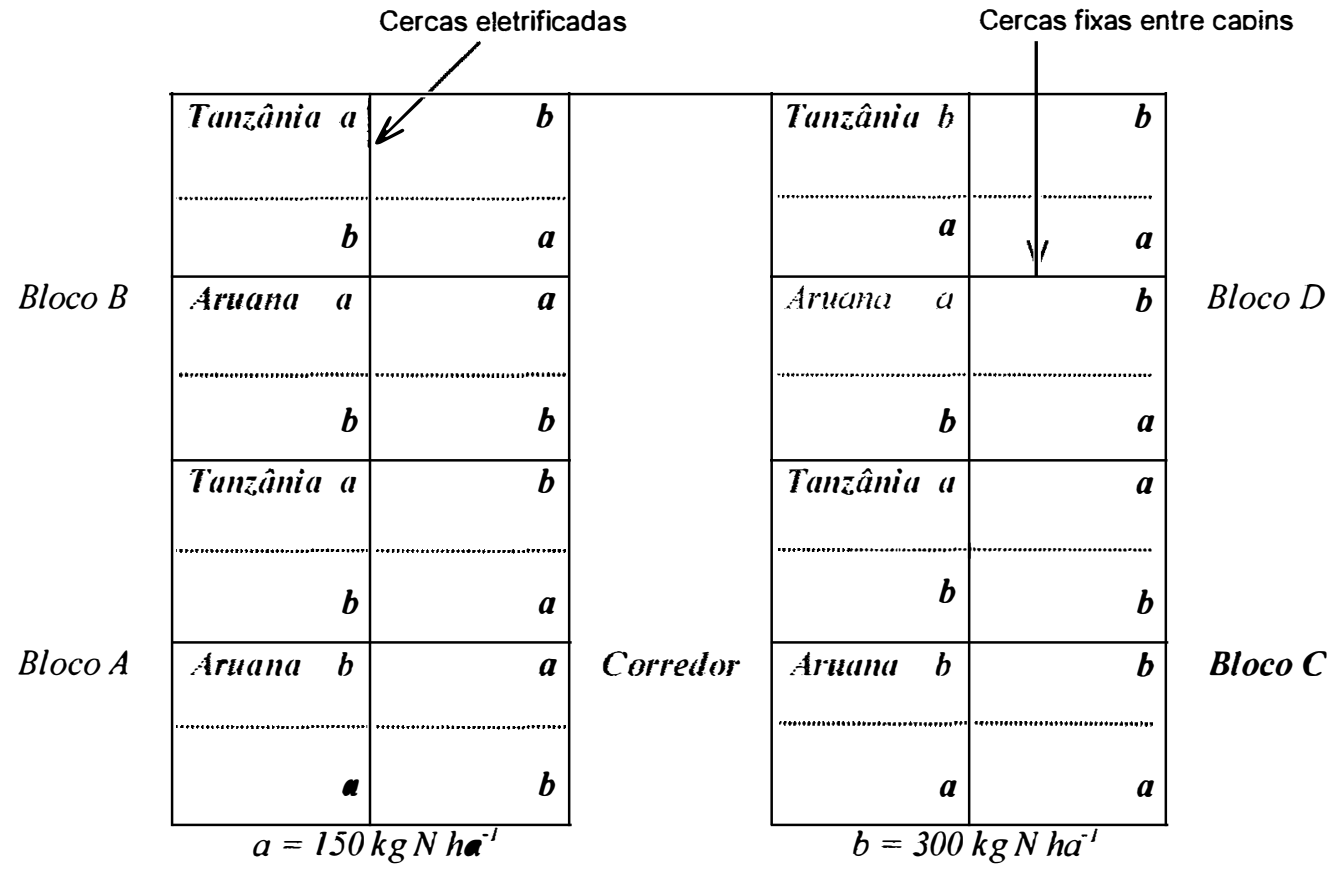

Figura 2 - Representação esquemática da distribuição dos tratamentos na área experimental

Cada capim foi pastejado independentemente por um lote de ovinos, sendo que cada um dos dois lotes foi constituido de animais de três raças diferentes (Santa Inês, Suffolk e lle de France), e suas categorias variando de acordo com o manejo do rebanho ao longo do periodo experimental.

Metade de cada parcela dos capins recebeu adubação nitrogenada de $150 \mathrm{~kg}$ $\mathrm{ha}^{-1} \mathrm{ano}^{-1}$ de $\mathrm{N}$ e a outra metade de $300 \mathrm{~kg} \mathrm{ha}^{-1} \mathrm{ano}^{-1}$ de $\mathrm{N}$, constituindo-se as doses de nitrogênio subparcelas que foram pastejadas simultaneamente (sem separação por cercas). A aplicação de cada dose de $\mathrm{N}$ foi parcelada com $1 / 3$ no início das águas (novembro / dezembro) e os outros $2 / 3$ no final das águas (março / abril), baseado em Werner (1970/71). 


\subsection{Monitoramento do pastejo}

Conforme diagrama da Figura 2, o piquete de cada capim foi dividido ao meio com cerca eletrificada. Cada metade do piquete de cada capim foi pastejada por um lote de ovinos, sendo que os animais iniciavam o pastejo na primeira metade de cada piquete (doses de $\mathrm{N}$ pastejadas simultaneamente), onde permaneciam de três a sete dias, passando então para a segunda metade do mesmo piquete, e assim sequencialmente em todos os blocos.

As categorias e raças animais utilizadas para pastejo variaram ao longo do periodo experimental (borregas, ovelhas secas, ovelhas prenhes, ovelhas de descarte), de acordo com o manejo do rebanho, pois o experimento foi realizado dentro de um sistema de produção de ovinos. O número de animais disponiveis para serem utilizados foi restrito na maior parte do periodo experimental, acarretando ausência de critério pré-pastejo para definir a entrada dos animais (por exemplo altura do relvado), pois procurou-se deixar a altura residual pós-pastejo em $20 \mathrm{~cm}$, sendo os animais liberados para continuarem a sequência de pastejo somente quando essa altura fosse atingida. Em consequência disso, o periodo de descanso foi variável. Tentou-se também respeitar o crescimento dos capins de acordo com a época do ano.

Foram estudados seis ciclos de pastejo ao longo do periodo experimental, para avaliação da parte aérea, sendo que em quatro deles foram feitas avaliações do sistema radicular, seguindo o cronograma: aplicação de 2/3 das doses de $\mathrm{N}$ em março e abril/02; $C 1=1^{\circ}$ ciclo de pastejo: de 09/05/02 a 03/07/02 (outono)- parte aérea e sistema radicular, $\mathrm{C} 2=2^{\circ}$ ciclo de pastejo: de 04/07/02 a 26/08/02 (inverno)- parte aérea e sistema radicular; $\mathrm{C} 3=3^{\circ}$ ciclo de pastejo: de 27/08/02 a 17/10/02 (inverno/primavera)- parte aérea e sistema radicular; aplicação de $1 / 3$ das doses de $\mathrm{N}$ em novembro e dezembro/02; $\mathrm{C} 4=4^{\circ}$ ciclo de pastejo: de 13/11/02 a 23/12/02 (primavera)- parte aérea; $C 5=5^{\circ}$ ciclo de pastejo: de 19/12/02 a 05/02/03 (verão)parte aérea e sistema radicular; $C 6=6^{\circ}$ ciclo de pastejo: de 13/02/03 a 28/03/03 (verão)- parte aérea (Tabela 3). 
Tabela 3. Datas pré-pastejo e pós-pastejo para cada parcela de cada capim nos blocos experimentais

\begin{tabular}{cccccccccc}
\hline & BL & A & A & B & B & C & C & D & D \\
\hline C1 & Pré & $09 / 05$ & $16 / 05$ & $21 / 05$ & $28 / 05$ & $04 / 06$ & $11 / 06$ & $18 / 06$ & $27 / 06$ \\
& Pós & $16 / 05$ & $21 / 05$ & $28 / 05$ & $04 / 06$ & $11 / 06$ & $18 / 06$ & $27 / 06$ & $04 / 07$ \\
C2 & Pré & $04 / 07$ & $11 / 07$ & $16 / 07$ & $23 / 07$ & $01 / 08$ & $07 / 08$ & $14 / 08$ & $21 / 08$ \\
& Pós & $11 / 07$ & $16 / 07$ & $22 / 07$ & $31 / 07$ & $07 / 08$ & $14 / 08$ & $21 / 08$ & $27 / 08$ \\
C3 & Pré & $27 / 08$ & $02 / 09$ & $05 / 09$ & $10 / 09$ & $16 / 09$ & $25 / 09$ & $03 / 10$ & $08 / 10$ \\
& Pós & $02 / 09$ & $05 / 09$ & $10 / 09$ & $16 / 09$ & $25 / 09$ & $30 / 09$ & $08 / 10$ & $17 / 10$ \\
C4 & Pré & $13 / 11$ & $20 / 11$ & $26 / 11$ & $02 / 12$ & $09 / 12$ & $17 / 12$ & $28 / 12$ & $05 / 12$ \\
& Pós & $20 / 11$ & $26 / 11$ & $02 / 12$ & $09 / 12$ & $17 / 12$ & $23 / 12$ & $05 / 01$ & $13 / 12$ \\
C5 & Pré & $19 / 12$ & $26 / 12$ & $08 / 01$ & $13 / 01$ & $22 / 01$ & $06 / 02$ & $20 / 01$ & $29 / 01$ \\
& Pós & $26 / 12$ & $31 / 12$ & $13 / 01$ & $20 / 01$ & $04 / 02$ & $14 / 02$ & $29 / 01$ & $05 / 02$ \\
C6 & Pré & $15 / 02$ & $20 / 02$ & $27 / 02$ & $07 / 03$ & $10 / 03$ & $14 / 03$ & $17 / 03$ & $24 / 03$ \\
& Pós & $20 / 02$ & $27 / 02$ & $07 / 03$ & $10 / 03$ & $14 / 03$ & $17 / 03$ & $24 / 03$ & $28 / 03$ \\
\hline
\end{tabular}

No ciclo de pastejo C4 observa-se que dois blocos ( $B=02 / 12$ e $D=05 / 12$ ) foram pastejados quase simultaneamente, por lotes de animais diferentes, sendo que 0 mesmo ocorreu no $C 5(B=20 / 01$ e $D=29 / 01$ ) (Tabela 3), devido ao rápido crescimento dos capins pelas condições favoráveis de temperatura e precipitação pluviomética.

Os períodos de pastejo foram precedidos por seis periodos de rebrotação (R), com média de $43,49,43,77,38$ e 43 dias respectivamente (Tabela 4).

Nenhuma avaliação foi feita sobre produção ou desempenho animal, sendo que os mesmos cumpriram apenas a função de agentes desfoliadores. 
Tabela 4. Datas e média de dias de rebrotação que precederam os seis ciclos de pastejo analisados

\begin{tabular}{|c|c|c|c|c|c|c|}
\hline \multirow[b]{2}{*}{ BL } & \multicolumn{2}{|l|}{ R1 } & \multicolumn{2}{|l|}{ R2 } & \multicolumn{2}{|l|}{ R3 } \\
\hline & data & dias & data & Dias & Data & dias \\
\hline A & $27 / 03$ a $09 / 05$ & 43 & $16 / 05$ a $04 / 07$ & 49 & $11 / 07$ a $27 / 08$ & 47 \\
\hline A & $03 / 04$ a $16 / 05$ & 43 & $21 / 05$ a $11 / 07$ & 51 & $16 / 07$ a $02 / 09$ & 48 \\
\hline B & $10 / 04$ a $21 / 05$ & 41 & $28 / 05$ a $16 / 07$ & 49 & $22 / 07$ a $05 / 09$ & 45 \\
\hline B & $17 / 04$ a $28 / 05$ & 41 & $04 / 06$ a $23 / 07$ & 49 & $31 / 07$ a $10 / 09$ & 42 \\
\hline C & $24 / 04$ a $04 / 06$ & 41 & $11 / 06$ a 01/08 & 51 & 07/08 a 16/09 & 40 \\
\hline C & $30 / 04$ a $11 / 06$ & 42 & $18 / 06$ a $07 / 08$ & 50 & $14 / 08$ a $25 / 09$ & 42 \\
\hline D & $05 / 05$ a $18 / 06$ & 44 & $27 / 06$ a $14 / 08$ & 48 & $21 / 08$ a $03 / 10$ & 43 \\
\hline D & $09 / 05$ a $27 / 06$ & 49 & 04/07 a 21/08 & 48 & $27 / 08$ a $08 / 10$ & 42 \\
\hline \multirow[t]{2}{*}{ Méd } & & 43 & & 49 & & 43 \\
\hline & \multicolumn{2}{|l|}{ R4 } & \multicolumn{2}{|l|}{ R5 } & \multicolumn{2}{|l|}{ R6 } \\
\hline BL & data & dias & data & Dias & data & dias \\
\hline A & $02 / 09$ a $13 / 11$ & 72 & $20 / 11$ a $19 / 12$ & 29 & $26 / 12$ a $15 / 02$ & 51 \\
\hline A & $05 / 09$ a $20 / 11$ & 76 & $26 / 11$ a $26 / 12$ & 30 & $31 / 12$ a $20 / 02$ & 52 \\
\hline B & $10 / 09$ a $26 / 11$ & 77 & $02 / 12$ a $08 / 01$ & 37 & $13 / 01$ a $25 / 02$ & 43 \\
\hline B & $16 / 09$ a $02 / 12$ & 77 & 09/12 a 13/01 & 35 & $20 / 01$ a $07 / 03$ & 46 \\
\hline C & $25 / 09$ a $09 / 12$ & 75 & $17 / 12$ a $22 / 01$ & 36 & $04 / 02$ a $10 / 03$ & 34 \\
\hline C & $30 / 09$ a $17 / 12$ & 79 & $23 / 12$ a $06 / 02$ & 45 & $14 / 02$ a $13 / 03$ & 27 \\
\hline D & $08 / 10$ a $28 / 12$ & 81 & 05/12 a 20/01 & 46 & $29 / 01$ a $17 / 03$ & 47 \\
\hline D & $17 / 10$ a $05 / 01$ & 80 & $13 / 12$ a $29 / 01$ & 47 & $05 / 02$ a $24 / 03$ & 47 \\
\hline Méd & & 77 & & 38 & & 43 \\
\hline
\end{tabular}

\subsection{Análise estatística}

A análise de variância dos dados foi realizada por meio do procedimento MIXED do pacote estatístico SAS (Statistical Analysis System) (SAS Institute, 1999) verão 8.02 para Windows. As interações significativas foram comparadas através do teste de Tukey a $10 \%$. 


\subsection{Amostragens e variáveis avaliadas}

\subsubsection{Parte aérea}

\subsubsection{Massa de forragem}

A massa de forragem antes e depois do pastejo foi obtida por meio do lançamento, ao acaso, de um quadrado de $0,5 \times 0,5 \mathrm{~m}\left(0,25 \mathrm{~m}^{2}\right)$ em quatro pontos dentro de cada unidade experimental, perfazendo um total de $1,0 \mathrm{~m}^{2}$ de área amostrada. O corte foi feito a $5 \mathrm{~cm}$ do solo com tesoura de poda. A forragem verde proveniente desses quatro pontos foi combinada, pesada, amostrada e as amostras colocadas em estufa com circulação de ar forçada a $65^{\circ} \mathrm{C}$ até peso constante, para determinação dos teores de matéria seca. A massa de forragem da amostra de cada unidade experimental teve seu valor convertido para $\mathrm{Mg} \mathrm{ha}^{-1}$ de $\mathrm{MS}$.

\subsubsection{Acúmulo de forragem}

O acúmulo de forragem (produção) foi obtido utilizando-se a seguinte equação:

$$
A F=M F i-M F f
$$

$\mathrm{AF}=$ acúmulo de forragem;

$\mathrm{MFi}$ = massa de forragem em pré-pastejo;

MFf = massa de forragem em pós-pastejo do periodo anterior.

As taxas de acúmulo foram obtidas dividindo-se a massa de forragem acumulada pelo número de dias entre pastejos, gerando-se os valores de taxa de acúmulo para cada unidade experimental ( $\mathrm{kg} \mathrm{ha}^{-1} \mathrm{dia}^{-1}$ de $\mathrm{MS}$ ) em cada período de avaliação (periodo de pastejo). Durante o período em que os animais permaneceram pastejando (três a sete dias), o acúmulo de forragem foi considerado nulo.

\subsubsection{Separação dos componentes e número de perfilhos}

Após retirada a amostra mencionada no item 3.7.1.1, o restante do material foi separado em seus componentes material morto, capim e plantas invasoras, que foram então pesados e amostrados. Do componente capim foi retirada uma outra amostra de 
aproximadamente $200 \mathrm{~g}$, na qual foram contados o número de perfilhos (aéreos + basais). Todas as amostras assim obtidas foram colocadas em estufa com circulação de ar forçada a $65^{\circ} \mathrm{C}$ até peso constante, para determinação dos teores de matéria seca.

\subsubsection{Altura do dossel forrageiro}

Foi medida a altura do dossel utilizando-se uma régua de 1,50 metro de comprimento graduada em centímetros, por ocasião das coletas de forragem (pré e pós-pastejo). Foram realizadas leituras da altura em 20 pontos, tomados ao acaso, dentro de cada unidade experimental. A altura de cada ponto correspondeu à altura média do dossel (camada de folhas) em torno da régua, e a média dos 20 pontos correspondeu a altura média da unidade experimental.

\subsubsection{Sistema radicular}

\subsubsection{Avaliação de raizes pré-pastejo}

Foram coletadas, antes da entrada dos animais, quatro amostras de raízes de cada unidade experimental, na profundidade de zero a $20 \mathrm{~cm}$. Foi utilizada uma sonda de dois $\mathrm{cm}$ de diâmetro, sendo o volume de terra coletado de $62,8 \mathrm{~cm}^{3}$. Essas quatro amostras foram combinadas em uma amostra composta com volume de terra total de $251,2 \mathrm{~cm}^{3}$. As amostras foram coletadas ao lado da base de touceiras representativas da área, selecionadas por meio do método da reta transecta (Carvalho et al., 2003), de maneira que representassem o tamanho médio das touceiras presentes na unidade experimental.

Todo o material coletado foi lavado em água corrente, utilizando-se uma peneira de malha de $0,25 \mathrm{~mm}$, separando as raizes do solo. Após lavagem, era feita a limpeza e a separação das raizes, que foram acondicionadas numa solução contendo $70 \%$ de álcool etílico para análises posteriores. 


\subsubsection{Crescimento do sistema radicular após o pastejo}

Após a saída dos animais foram feitos, em cada unidade experimental, oito buracos cilíndricos no perfil do solo, usando a mesma sonda de $2 \mathrm{~cm}$ de diâmetro, na profundidade de zero a $20 \mathrm{~cm}$, ao lado da base de quatro touceiras representativas da área (Carvalho et al., 2003) (identificadas com estacas de madeira), sendo dois buracos ao lado de cada touceira. O solo foi retirado, os buracos preenchidos com areia de construção e cobertos, então, com uma camada de argila de aproximadamente $15 \mathrm{~mm}$, pressionada no topo de cada buraco para agir como lacre, conforme método descrito por Matthew (1992). A cada sete dias era sorteada uma das quatro touceiras e retirado o conteúdo dos dois buracos feitos ao seu lado. $O$ conteúdo dos dois buracos foi combinado de forma a compor uma amostra com volume de 125,6 $\mathrm{cm}^{3}$.

O procedimento de lavagem, limpeza e acondicionamento do material coletado foi idêntico ao descrito no item 3.7.2.1.

\subsubsection{Variáveis do sistema radicular}

As raizes das coletas referentes aos itens 3.7.2.1 e 3.7.2.2 foram retiradas do álcool e coradas numa solução de $0,5 \%$ de Azul de Metileno por cinco minutos, e então distribuídas em bandeja de vidro de $36 \times 23 \mathrm{~cm}$ e $3,5 \mathrm{~cm}$ de altura, com $150 \mathrm{ml}$ de água. Essa bandeja foi colocada sobre um scanner de mesa com resolução de 300 dpi. As imagens das raizes obtidas pela varredura efetuada pelo scanner e transferidas automaticamente para um arquivo no computador, foram consideradas imagens já digitalizadas, prontas para o processamento do cálculo do comprimento total e superficie radicular. O comprimento total e a superfície das raizes foram estimados pelo sistema Delta T SCAN Image Analisys Software, que fornece medidas acuradas do comprimento e superfície de raizes (Greenwood \& Hutchinson, 1998; Bouma et al., 2000) expresso em unidade por volume de solo. Após isso as amostras de raizes foram colocadas em estufa com circulação de ar forçada a $65^{\circ} \mathrm{C}$ até peso constante, e pesadas para determinação dos teores de matéria seca. Posteriormente foram colocadas na mufla a $650^{\circ} \mathrm{C}$ por 4 horas para determinação da matéria mineral, necessária para o cálculo da massa da matéria orgânica das raízes. 
$\mathrm{Na}$ avaliação de raízes pré-pastejo, foi determinada a massa seca da matéria orgânica (MSMO), o comprimento e superficie de raizes. Os valores foram expressos em $\mathrm{mg} \mathrm{cm}^{-3}, \mathrm{~cm} \mathrm{~cm}^{-3} \mathrm{e} \mathrm{cm}^{-2} \mathrm{~cm}^{-3}$ de solo, respectivamente. $\mathrm{Na}$ avaliação do crescimento radicular pós-pastejo, os valores de MSMO, comprimento e superfície de raizes foram expressos em $\mathrm{mg} 125,6 \mathrm{~cm}^{-3}, \mathrm{~cm} 125,6 \mathrm{~cm}^{-3} \mathrm{e} \mathrm{cm}^{-2} 125,6 \mathrm{~cm}^{-3}$ de solo, respectivamente. 


\section{RESULTADOS E DISCUSSÃO}

\subsection{Parte aérea}

\subsubsection{Massa de forragem e dos seus componentes}

$\mathrm{Na}$ Tabela 5 são apresentados os dados referentes à massa de forragem e seus componentes (capim, material morto e plantas invasoras) no dossel forrageiro, em seis ciclos de pastejo.

Para a massa de forragem pré-pastejo e para o componente capim não houve interação de capins, doses de $\mathrm{N}$ e ciclos de pastejo $(P>0,10)$, assim como não foram observadas diferenças entre capins $(P>0,10)$, doses de $N(P>0,10)$ (Apêndice - Tabela 1 ), e nem interação capins $x$ doses de $N(P>0,10)$. Na média dos ciclos de pastejo, a massa de forragem pré-pastejo foi de 4,19 e 4,73 $\mathrm{Mg} \mathrm{ha}^{-1}$ de $\mathrm{MS}$ para os capins Aruana e Tanzânia, e de 4,20 e 4,71 Mg ha-1 de MS para as doses de 150 e $300 \mathrm{~kg} \mathrm{ha}^{-}$ ${ }^{1}$ de $\mathrm{N}$, respectivamente. O componente capim apresentou médias dos seis ciclos de 3,2 e 3,4 Mg ha-1 de MS para os capins Aruana e Tanzânia, e de 3,1 e 3,5 $\mathrm{Mg} \mathrm{ha}^{-1} \mathrm{de}$ MS para as doses de 150 e $300 \mathrm{~kg} \mathrm{ha}^{-1}$ de $\mathrm{N}$, respectivamente.

Os resultados obtidos concordam com os de Cecato (1993), que não obteve resposta do capim-Aruana à aplicação de 100 ou $200 \mathrm{~kg} \mathrm{ha}^{-1} \mathrm{ano}^{-1} \mathrm{de} \mathrm{N}$, parcelado ou não, na estação de estabelecimento e primeira seca. Somente houve efeito na segunda estação de chuvas, onde a testemunha apresentou produção inferior à das parcelas que receberam doses de nitrogênio, sendo que estas não diferiram entre si.

Tosi (1999) e Rosseto (2000) realizaram experimento com o capim-Tanzânia utilizando duas doses de nitrogênio (50 e $80 \mathrm{~kg} \mathrm{ha}^{-1}$ de $\mathrm{N}$ após cada pastejo) e duas alturas de corte $(20$ e $35 \mathrm{~cm}$ ), e constataram que a produção de massa seca diferiu devido às condições climáticas, com valores próximos de 6.500 e $4.000 \mathrm{~kg} \mathrm{ha}^{-1}$ de MS no verão e 2.500 e $1.280 \mathrm{~kg} \mathrm{ha}^{-1}$ de $\mathrm{MS}$ no inverno (aproximadamente $22 \%$ da 
produção total) para as duas doses de N. A magnitude da diferença de produção entre verão e inverno foi diferente da obtida no presente trabalho.

Para os componentes material morto e plantas invasoras observou-se diferença entre capins $(P<0,10)$, mas não entre doses de $N(P>0,10)$ nem da interação capins $x$ doses de $N(P>0,10)$.

Tabela 5. Massa de forragem pré-pastejo e componentes do dossel forrageiro, nos seis ciclos de pastejo avaliados

\begin{tabular}{|c|c|c|c|c|c|c|c|c|}
\hline \multirow[b]{2}{*}{ Fatores } & \multicolumn{6}{|c|}{ Ciclos de Pastejo } & \multirow[b]{2}{*}{ Média } & \multirow[b]{2}{*}{ EPM } \\
\hline & $\begin{array}{c}C 1 \\
09 / 05 a \\
27 / 06 / 02\end{array}$ & $\begin{array}{c}C 2 \\
04 / 07 \text { a } \\
21 / 08 / 02 \\
\end{array}$ & $\begin{array}{c}\text { C3 } \\
27 / 08 \text { a } \\
08 / 10 / 02 \\
\end{array}$ & $\begin{array}{c}C 4 \\
13 / 11 \text { a } \\
05 / 12 / 02 \\
\end{array}$ & $\begin{array}{c}\text { C5 } \\
19 / 12 / 02 \text { a } \\
29 / 01 / 03 \\
\end{array}$ & $\begin{array}{c}C 6 \\
15 / 02 \text { a } \\
24 / 03 / 03 \\
\end{array}$ & & \\
\hline \multicolumn{9}{|c|}{ Total (Mg MS ha-1) } \\
\hline Média & $4,97^{B}$ & $3,57^{\mathrm{CD}}$ & $3,30^{\mathrm{D}}$ & $4,18^{\mathrm{BC}}$ & $4,63^{B}$ & $6,10^{A}$ & 4,46 & 0,370 \\
\hline EPM & 0,37 & 0,37 & 0,37 & 0,37 & 0,37 & 0,37 & & \\
\hline \multicolumn{9}{|c|}{ Capim (Mg MS ha'-1) } \\
\hline Média & $3,7^{B}$ & $1,8^{C}$ & $2,0^{\mathrm{C}}$ & $3,7^{\mathrm{B}}$ & $3,9^{\mathrm{B}}$ & $4,8^{A}$ & 3,3 & 0,28 \\
\hline EPM & 0,37 & 0,17 & 0,15 & 0,33 & 0,33 & 0,35 & & \\
\hline \multicolumn{9}{|c|}{ Material Morto (Mg MS ha-1) } \\
\hline Aruana & $1,0^{\mathrm{aA}}$ & $1,2^{\mathrm{bA}}$ & $0,8^{\mathrm{bA}}$ & $0,5^{\mathrm{aB}}$ & $0,8^{\mathrm{aA}}$ & $1,1^{\mathrm{aA}}$ & $0,9^{b}$ & 0,08 \\
\hline Tanzânia & $1,3^{\mathrm{aB}}$ & $2,2^{\mathrm{aA}}$ & $1,8^{\mathrm{aA}}$ & $0,4^{\mathrm{aC}}$ & $0,6^{\mathrm{aC}}$ & $1,3^{\mathrm{aB}}$ & $1,3^{\mathrm{a}}$ & 0,08 \\
\hline \multicolumn{9}{|c|}{ Plantas Invasoras (Mg MS ha ${ }^{-1}$ ) } \\
\hline Aruana & $0,20^{\mathrm{aA}}$ & $0,03^{\mathrm{aC}}$ & $0,02^{\mathrm{aC}}$ & $0,07^{\mathrm{aB}}$ & $0,03^{\mathrm{aC}}$ & $0,08^{a B}$ & $0,07^{a}$ & 0,010 \\
\hline Tanzânia & $0,00^{\mathrm{bA}}$ & $0,00^{\mathrm{bA}}$ & $0,00^{\mathrm{aA}}$ & $0,00^{\mathrm{bA}}$ & $0,00^{\mathrm{bA}}$ & $0,02^{\mathrm{bA}}$ & $0,00^{b}$ & 0,010 \\
\hline
\end{tabular}

\footnotetext{
${ }^{\text {ab }}$ Médias na mesma coluna seguidas da mesma letra minúscula não diferem entre si $(p>0,10)$.

${ }^{A B}$ Médias na mesma linha seguidas da mesma letra maiúscula não diferem entre si $(p>0,10)$.

EPM: erro padrão da média.
}

O capim-Tanzânia apresentou maior quantidade de material morto no segundo (C2) e terceiro (C3) ciclos de pastejo, correspondentes à época da seca, e também na média entre os ciclos, quando sua quantidade foi $28 \%$ maior do que no capim-Aruana (Tabela 5). Este fato pode ter ocorrido em função do efeito residual do florescimento do capim-Tanzânia, que pode ter favorecido maior quantidade de hastes e material morto, pois o crescimento vegetativo cessa durante o florescimento. Zimmer (1999) reportou 
que a massa média de material morto do capim-Aruana foi de $1,68 \mathrm{Mg} \mathrm{ha}^{-1}$ na estação seca e de 2,00 Mg ha-1 na estação de chuvas, valores semelhantes aos obtidos no presente trabalho.

Já o capim-Aruana apresentou maiores massas de plantas invasoras que o capim-Tanzânia em quase todos os ciclos de pastejo e na média entre os ciclos, sendo a exceção o terceiro ciclos (C3), correspondente ao final da estação de inverno. No verão que antecedeu o primeiro ciclo de pastejo $(C 1)$, houve acentuado ataque de cigarrinhas, o que prejudicou o desenvolvimento do capim-Aruana, fornecendo condições para maior proliferação de plantas invasoras. Pode-se observar o efeito da adubação nitrogenada aplicada antes do início das avaliações, pois houve decréscimo na quantidade de plantas invasoras nos ciclos C2 e C3 (inverno), aumentando na primavera (C4), quando novamente foi aplicada a adubação nitrogenada restante, provocando acentuada queda na infestação (C5), que aumentou novamente no ciclo de verão (C6). Já a quantidade de plantas invasoras presentes nas parcelas do capimTanzânia foi muito pequena, provavelmente devido ao seu maior porte e rápida rebrota inicial.

Não houve efeito das doses de $\mathrm{N}$ para os componentes material morto $\mathrm{e}$ plantas invasoras (Apêndice - Tabela 1) $(P>0,10)$, e também não houve interação capins $x$ doses de $N(P>0,10)$. Nesse sentido, Zimmer (1999), estudando o efeito da adubação nitrogenada de zero e $150 \mathrm{~kg} \mathrm{ha}^{-1}$ de $\mathrm{N}$ sobre a quantidade de material morto após a implantação de pastagem de capim-Aruana e na segunda e terceira estações de chuvas subsequentes, não encontrou diferenças entre as doses de $\mathbf{N}$ aplicadas, com quantidade semelhante de MS de material morto para os tratamentos, afirmando que isso pode ter sido consequência do aumento na senescência de folhas na ausência de adubação com $\mathrm{N}$, devido à translocação do $\mathrm{N}$ das folhas velhas da base da planta para as partes mais jovens em crescimento. Entretanto, no presente estudo, a possivel causa para a falta de resposta às doses de nitrogênio pode ter sido a alta quantidade de matéria orgânica presente no solo da área experimental. Além disso foram aplicados $2 / 3$ da dose total de $\mathrm{N}$ em março / abril, o que melhorou a distribuição de produção de forragem ao longo do ano, mas não foi suficiente para fornecer respostas significativas para massa de forragem e seus componentes. $O$ restante da dose de $\mathrm{N}$ (1/3 da dose total) foi aplicado em novembro / dezembro, o que 
também não foi suficiente para mostrar respostas significativas de produção de forragem.

Quanto à massa de forragem pré-pastejo, observa-se que os ciclos C1 e C5 (outono e início de verão) foram semelhantes entre si $(P>0,10)$, assim como os ciclos C1, C4 e C5 (outono, primavera e início de verão) não diferiram entre si $(P>0,10)$. Comparando-se os ciclos C2, C3, C4 e C5 (início do inverno, final do inverno, primavera e início de verão), observa-se que os ciclos C2 e C3 foram semelhantes, o mesmo ocorrendo com os ciclos $\mathrm{C} 2$ e C4, e C4 e C5. Para efeito de comparação e melhor visualização, C1, C2 e C3 foram considerados como o periodo das secas ("inverno"), e C4, C5 e C6 como o período das águas ("verão"). Com os dados da Tabela 5, pode-se mostrar que a massa de forragem no "inverno" correspondeu a aproximadamente $45 \%$ do total, e a de capim $38 \%$. O que tendeu a igualar a disponibilidade de massa de forragem entre os ciclos de pastejo foram os períodos de descanso diferentes (Tabela 3).

Brâncio et al. (2000), avaliando a disponibilidade de MS do capim-Tanzânia com ou sem adubação nitrogenada em lotação rotacionada de sete dias de ocupação e 35 dias de descanso, encontraram valores de disponibilidade de MS de 2,82; 2,77; 2,71 e $5,45 \mathrm{Mg} \mathrm{ha}^{-1}$ nos meses de junho, setembro e novembro de 1998 e março de 1999.

Os dados de massa de forragem remanescente pós-pastejo estão apresentados na Tabela 6.

Tabela 6. Massa de forragem remanescente pós-pastejo em seis ciclos de pastejo

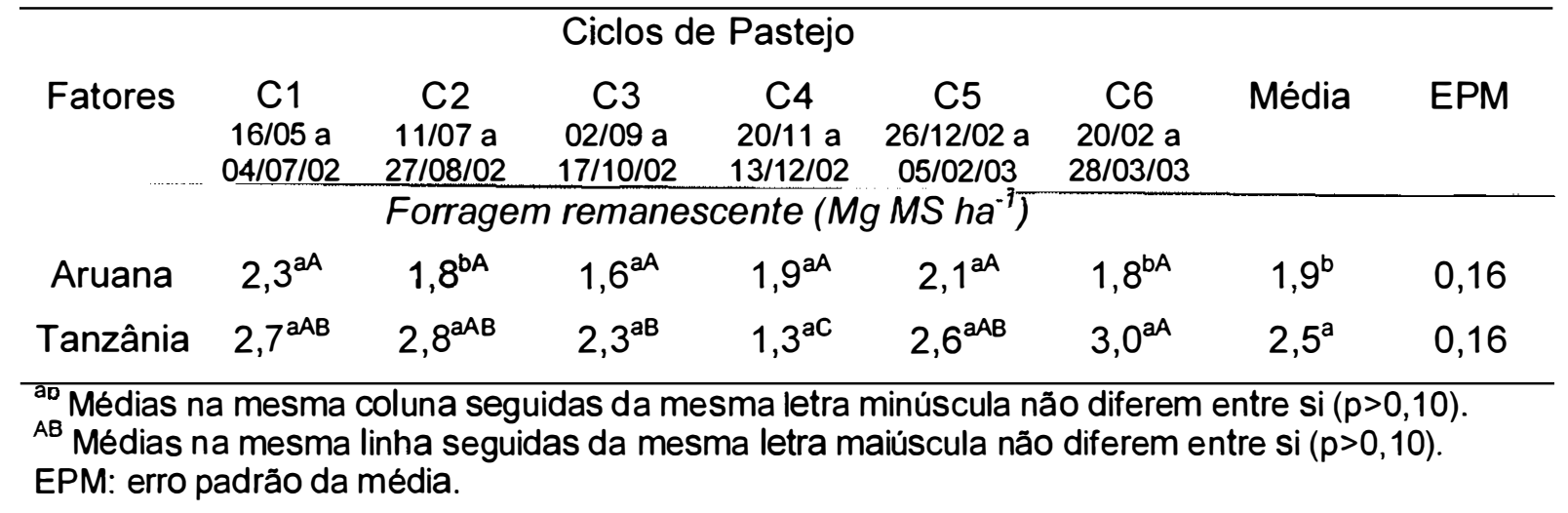


Foi constatada menor massa de forragem pós-pastejo para o capim-Aruana no segundo (C2) e sexto (C6) ciclos de pastejo, assim como na média dos ciclos $(P<0,10)$. A massa de forragem residual não diferiu entre ciclos de pastejo $(P>0,10)$ para 0 capim-Aruana, provavelmente porque havia muito material morto no resíduo que, no entanto, não foi quantificado. Gerdes (2003), estudando o capim-Aruana sobresemeado ou não com três espécies forrageiras de inverno, encontrou maiores resíduos para o capim-Aruana nos períodos relativos à primavera/verão no primeiro ano experimental (2000).

Para o capim-Tanzânia a maior massa residual ocorreu no sexto ciclo de pastejo (verão), quando a massa de forragem em pré-pastejo também foi maior. $O$ menor resíduo pós-pastejo para o capim-Tanzânia ocorreu no quarto ciclo (primavera), coincidindo com sua retomada de crescimento, e também com baixa quantidade de material morto no pré-pastejo.

Para as massas de forragem residuais, não foram observadas diferenças quanto às doses de $N$ (Apêndice - Tabela 2) ( $P>0,10)$, assim como também não houve interação capins $x$ doses de $N(P>0,10)$. $O$ fato de não ter sido realizada a separação dos componentes no resíduo pós-pastejo pode ter sido um dos motivos pelos quais não foi observada resposta à adubação nitrogenada, pois se a forragem não é colhida eficientemente, o material senesce e fica no resíduo pós-pastejo, aumentando sua quantidade. Na média entre os ciclos de pastejo, a massa de forragem pós-pastejo foi de 2,07 e 2,32 Mg ha-1 de MS para as doses de 150 e $300 \mathrm{~kg} \mathrm{ha}^{-1}$ de $\mathrm{N}$, respectivamente.

\subsubsection{Acúmulo de forragem}

Na Tabela 7 são apresentados os dados de acúmulo de forragem e da taxa média diária de acúmulo de forragem, em seis períodos de rebrotação, que antecederam os seis ciclos de pastejo. $O$ maior acúmulo de forragem, assim como da taxa média diária de acúmulo de forragem, ocorreu nos periodos de rebrotação R1, R5 e R6. Nos periodos de rebrotação referentes ao inverno (R2 e R3), o acúmulo e a taxa média diária de acúmulo de forragem foram menores $(P<0,10)$ do que nos outros periodos, o que era esperado pelas condições de baixa precipitação e temperatura nessas épocas (Figura 1). 
Gerdes (2003), trabalhando com capim-Aruana sobre-semeado ou não com espécies forrageiras de inverno, afirmou que a taxa média diária de acúmulo de forragem variou entre os seis periodos de rebrotação estudados ao longo de um ano, sendo que as taxas foram maiores no primeiro e quinto periodos (início de outono e primavera) e menores no segundo e terceiro periodos (final de outono e inverno). Reportou média total de acúmulo de forragem de $13,17 \mathrm{Mg} \mathrm{ha}^{-1}$ de $\mathrm{MS}$ para o capimAruana exclusivo, ao longo dos seis períodos de rebrotação estudados, valor que é da mesma magnitude do obtido no presente trabalho (Apêndice - Tabela 3).

Tabela 7. Acúmulo e taxa média diária de acúmulo de forragem em seis periodos de rebrotação $(R)$, média dos capins e das doses de $\mathrm{N}$

\section{Periodos de Rebrotação}

Fatores R1: 43 dias R2: 49 dias R3: 43 dias R4: 77 dias R5: 38 dias R6: 43 dias (outono) (inverno) (inverno) (primavera) (prim/ver) (verão) Acúmulo de Forragem ( $\mathrm{Mg} \mathrm{MS} \mathrm{ha^{-1 } )}$

$\begin{array}{ccccccc}\text { Média } & 2,7^{\mathrm{AB}} & 1,1^{\mathrm{C}} & 1,0^{\mathrm{C}} & 2,2^{\mathrm{BC}} & 2,9^{\mathrm{AB}} & 3,8^{\mathrm{A}} \\ \text { EPM } & 0,38 & 0,38 & 0,38 & 0,38 & 0,38 & 0,41\end{array}$

Taxa média diária de acúmulo de forragem ( $\left.\mathrm{kg} \mathrm{MS} \mathrm{ha}^{-1} \mathrm{dia}^{-1}\right)$

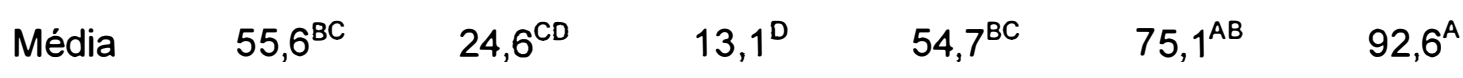

$\begin{array}{lllllll}\text { EPM } & 10,08 & 10,09 & 10,09 & 10,09 & 10,09 & 10,08\end{array}$

\footnotetext{
${ }^{A B}$ Médias na mesma linha seguidas da mesma letra maiúscula não diferem entre si $(p>0,10)$. EPM: erro padrão da média.
}

Para fins de comparação e melhor visualização do efeito da sistemática de adubação utilizada no presente trabalho, R1, R2 e R3 foram considerados como o período das secas ("inverno"), e R4, R5 e R6 como o periodo das águas ("verão"). Com os dados da Tabela 7 pode-se verificar que o acúmulo de forragem no "inverno" correspondeu a aproximadamente $39 \%$ do total, e a taxa média diária de acúmulo de forragem a $30 \%$, em virtude da estratégia de adubação utilizada, que promoveu melhor distribuição de forragem ao longo dos periodos estudados.

Como a massa de forragem pré-pastejo e o acúmulo de forragem não diferiram entre capins $(P>0,10)$, mas a massa de forragem remanescente pós-pastejo diferiu $(P<0,10)$, com o capim-Tanzânia apresentando maior massa de forragem pós-pastejo, 
pode-se inferir que provavelmente o mesmo foi menos consumido pelos animais, o que consequentemente contribuiu para maior massa de material morto em relação ao capim-Aruana (valores não mensurados). Uma possivel explicação para o menor consumo do capim-Tanzânia seria a estrutura de suas folhas, pois pôde-se observar que morfologicamente a base das lâminas era estreita, muito grossa e dura, provavelmente para sustentar seu peso (lâminas largas e compridas), e que não eram consumidas pelos animais (comportamento observado).

Não houve interação capins $x$ doses de $N \times$ periodos de rebrotação $(P>0,10)$, assim como não foram observadas diferenças entre capins $(P>0,10)$, doses de $N$ $(P>0,10)$ (Apêndice - Tabela 3), e interação capins $x$ doses de $N(P>0,10)$. Na média dos periodos de rebrotação, o acúmulo de forragem foi de 2,17 e 2,37 $\mathrm{Mg} \mathrm{ha}^{-1}$ de $\mathrm{MS}$ para os capins Aruana e Tanzânia, e de 2,14 e 2,40 Mg ha-1 de MS para as doses de 150 e $300 \mathrm{~kg} \mathrm{ha}^{-1}$ de $\mathrm{N}$, respectivamente. Os valores para acúmulo total de forragem foram de 13,03 e 14,24 Mg ha-1 de MS para os capins Aruana e Tanzânia, e de 12,84 e $14,44 \mathrm{Mg} \mathrm{ha}^{-1}$ de MS para as doses de 150 e $300 \mathrm{~kg} \mathrm{ha}^{-1}$ de $\mathrm{N}$, respectivamente. Com isso, observa-se que houve pequeno efeito da adubação nitrogenada para acúmulo e taxa média diária de acúmulo de forragem, sendo que a possivel explicação para esse fato pode ser a mesma fornecida para massa de forragem (item 4.1.1).

Também não houve interação capins $x$ doses de $\mathrm{N} \times$ periodos de rebrotação $(P>0,10)$, nem foram observadas diferenças entre capins $(P>0,10)$, doses de $N$ $(P>0,10)$ (Apêndice - Tabela 3), e interação capins $x$ doses de $N(P>0,10)$ para a taxa média diária de acúmulo de forragem. Na média entre os periodos de pastejo, a taxa média diária de acúmulo de forragem foi de 49,69 e 55,53 $\mathrm{kg} \mathrm{ha}^{-1} \mathrm{dia}^{-1}$ de MS para os capins Aruana e Tanzânia, e de 48,69 e 56,53 $\mathrm{kg} \mathrm{ha}^{-1}$ dia $^{-1}$ de MS para as doses de 150 e $300 \mathrm{~kg} \mathrm{ha}^{-1}$ de $\mathrm{N}$, respectivamente.

Favoretto et al. (1985) empregaram doses de nitrogênio de zero, 50 e $100 \mathrm{~kg}$ $\mathrm{ha}^{-1}$ em capim-Colonião, avaliando as respostas em termos de produção de massa seca durante o periodo de verão (novembro a março). Constataram aumento significativo na produção de massa seca e determinaram que as taxas de acúmulo de forragem do capim aumentaram de 47 para 68 e $83 \mathrm{~kg} \mathrm{ha}^{-1} \mathrm{dia}^{-1} \mathrm{com}$ os respectivos incrementos das doses desse nutriente, contrariando os resultados obtidos no presente trabalho. Também Soria (2002), estudando o efeito de diferentes lâminas de água aplicadas e adubação nitrogenada $\left(0,100,275,756\right.$ e $1.079 \mathrm{~kg} \mathrm{ha}^{-1}$ de $\left.\mathrm{N}\right)$ e suas 
interações durante nove ciclos de crescimento do capim-Tanzânia, verificou que as taxas médias de acúmulo obtidas durante o verão apresentaram variações para as doses de $\mathrm{N}$ usadas, com valores de 35,$7 ; 35,6 ; 55,6 ; 82,4$ e $133,9 \mathrm{~kg} \mathrm{ha}^{-1}$ de MS, respectivamente, no segundo periodo de coleta (janeiro/2001), tendendo ao decréscimo até o periodo de coleta 6 (julho/2001), atingindo os acúmulos mínimos médios de 9,$2 ; 9,5 ; 14,0 ; 20,5$ e $23,0 \mathrm{~kg} \mathrm{ha}^{-1}$ de $\mathrm{MS}$ para as doses de $\mathrm{N}$ usadas.

\subsubsection{Altura do dossel forrageiro}

$\mathrm{Na}$ Tabela 8 pode-se observar que a altura do dossel forrageiro pré-pastejo diferiu entre capins e doses de $N(P<0,10)$, mas não houve interação capins $x$ doses de $N(P>0,10)$.

Tabela 8. Altura do dossel forrageiro pré e pós-pastejo em seis ciclos de pastejo

\begin{tabular}{|c|c|c|c|c|c|c|c|c|}
\hline \multirow[b]{2}{*}{ Fatores } & \multicolumn{6}{|c|}{ Ciclos de Pastejo } & \multirow[b]{2}{*}{ Média } & \multirow[b]{2}{*}{ EPM } \\
\hline & $\begin{array}{c}\text { C1 } \\
09 / 05 \text { a } \\
03 / 07 / 02 \\
\end{array}$ & $\begin{array}{c}C 2 \\
04 / 07 \text { a } \\
26 / 08 / 02\end{array}$ & $\begin{array}{c}\text { C3 } \\
27 / 08 \text { a } \\
17 / 10 / 02\end{array}$ & $\begin{array}{c}\text { C4 } \\
13 / 11 \mathrm{a} \\
23 / 12 / 02 \\
\end{array}$ & $\begin{array}{c}\text { C5 } \\
19 / 12 / 02 \text { a } \\
05 / 02 / 03\end{array}$ & $\begin{array}{c}C 6 \\
13 / 02 \text { a } \\
28 / 03 / 03 \\
\end{array}$ & & \\
\hline \multicolumn{9}{|c|}{ Altura do dossel forrageiro $(\mathrm{cm})$ pré-pastejo } \\
\hline Aruana & $46,6^{\mathrm{aB}}$ & $33,8^{a B}$ & $41,2^{\mathrm{aB}}$ & $74,6^{\mathrm{bA}}$ & $80,9^{\mathrm{bA}}$ & $82,9^{\mathrm{bA}}$ & $60,0^{b}$ & 2,01 \\
\hline Tanzânia & $56,6^{\mathrm{aB}}$ & $33,5^{\mathrm{aC}}$ & $42,6^{\mathrm{aBC}}$ & $102,0^{\mathrm{aA}}$ & $106,6^{\mathrm{aA}}$ & $119,4^{\mathrm{aA}}$ & $76,89^{a}$ & 2,01 \\
\hline \multicolumn{9}{|c|}{ Altura do dossel forrageiro $(\mathrm{cm})$ pré-pastejo } \\
\hline $150 \mathrm{~kg} \mathrm{~N}$ & $48,5^{a}$ & $30,8^{a}$ & $38,9^{a}$ & $82,6^{a}$ & $88,8^{a}$ & $99,7^{a}$ & $64,9^{b}$ & 1,99 \\
\hline $300 \mathrm{~kg} \mathrm{~N}$ & $54,7^{a}$ & $36,5^{\mathrm{a}}$ & $45,0^{a}$ & $94,0^{a}$ & $98,7^{\mathrm{a}}$ & $102,7^{a}$ & $71,9^{a}$ & 1,99 \\
\hline \multicolumn{9}{|c|}{ Altura do dossel forrageiro $(\mathrm{cm})$ pós-pastejo } \\
\hline Aruana & $23,4^{\mathrm{aB}}$ & $19,3^{\mathrm{aC}}$ & $15,2^{\mathrm{aD}}$ & $62,1^{\mathrm{aA}}$ & $41,7^{\mathrm{aA}}$ & $50,8^{a A}$ & $35,4^{a}$ & 2,35 \\
\hline Tanzânia & $22,6^{\mathrm{aB}}$ & $18,7^{\mathrm{aC}}$ & $17,2^{\mathrm{aC}}$ & $36,2^{\mathrm{bABC}}$ & $38,9^{\mathrm{aA}}$ & $44,2^{\mathrm{bA}}$ & $29,6^{b}$ & 2,35 \\
\hline
\end{tabular}

As maiores alturas pré-pastejo para ambos os capins ocorreram nos ciclos de pastejo C4, C5 e C6 (primavera e verão), e as menores nos ciclos C2 e C3 (inverno), acompanhando as variações climáticas pertinentes às estações do ano, pois no verão 
o crescimento dos capins foi maior (Tabela 7) e, como explicado no item 3.5, não houve critério de entrada dos animais baseado na altura pré-pastejo. A dose de $300 \mathrm{~kg}$ $\mathrm{ha}^{-1}$ de $\mathrm{N}$ contribuiu para uma maior altura pré-pastejo do dossel forrageiro na média entre os ciclos $(P<0,10)$, e o capim-Tanzânia apresentou maior altura pré-pastejo $(P<0,10)$ a partir do $C 4$ e na média entre os ciclos.

A altura do dossel forrageiro pós-pastejo diferiu entre capins $(P<0,10)($ Tabela 8), mas não diferiu entre doses de $N$, nem ocorreu interação capins $x$ doses de $N$ $(P>0,10)$ (Apêndice - Tabela 4). A média da altura do dossel forrageiro pós-pastejo (Apêndice - Tabela 4) foi de 29,84 e 35,22 cm para as doses de 150 e $300 \mathrm{~kg} \mathrm{ha}^{-1}$ de $\mathrm{N}$, respectivamente. O capim-Aruana apresentou maior altura pós-pastejo nos ciclos C4 e C6 (primavera e verão) e na média entre os ciclos. Foi observado intenso florescimento do capim-Aruana durante o verão, o que pode ter sido causa dessa maior altura pós-pastejo, pois notou-se que o residuo era composto basicamente de hastes, que não foram consumidas pelos animais (observação visual).

Embora a altura preconizada para o residuo pós-pastejo tenha sido de $20 \mathrm{~cm}$, esta só foi atingida nos ciclos de pastejo $\mathrm{C} 1, \mathrm{C} 2$ e C3 (outono, inverno e inverno/primavera. A partir do $\mathrm{C} 4$, quando a pluviosidade e temperatura começaram a aumentar (Figura 1), o controle da altura do residuo foi perdido. Esse fato pode ter acontecido por alguns motivos, entre os quais: o efeito residual da adubação nitrogenada aplicada em março/abril, que promoveu rápida rebrotação com o aumento da pluviosidade, levando a uma rápida elongação das hastes (observação visual), que eram pouco consumidas pelos animais; o número de animais disponivel para utilização na área experimental foi restrito durante alguns periodos dentro da estação de crescimento devido à estratégia de manejo do rebanho (por exemplo, estação de monta), não sendo possivel aumentar a lotação com finalidade de acelerar o ciclo de pastejo e diminuir o periodo de descanso; os dois capins estudados possuem estrutura morfológica diferente e foram manejados da mesma maneira, ora favorecendo-se um, ora outro; além disso houve dificuldade de se manejar as subparcelas com as doses de $\mathrm{N}$ pastejadas simultaneamente.

Na média geral o capim-Tanzânia apresentou maior altura pré-pastejo $(P<0,10)$, enquanto no pós-pastejo foi verificada maior altura do capim-Aruana. Neste último caso, esse valor maior foi devido a altura mensurada no C4, C5 e C6. 


\subsubsection{Número de perfilhos}

Quanto a densidade populacional de perfilhos, foi observada diferença entre capins $(P<0,10)$ (Tabela 9), mas não houve interação capins $x$ doses de $N \times$ ciclos de pastejo $(P>0,10)$, assim como não foram observadas diferenças entre as doses de $N$ $(P>0,10)$ (Apêndice - Tabela 5), nem interação capins $x$ doses de $N(P>0,10)$.

Galbeiro et al. (2002) e Menezes et al. (2001), trabalhando com capimTanzânia, também não encontraram efeito da adubação nitrogenada sobre a densidade populacional de perfilhos.

Observando-se a Tabela 9, pode-se verificar que o capim-Aruana apresentou maior densidade populacional de perfilhos em todos os ciclos de pastejo $(P<0,10)$ e na média dos ciclos $(P<0,10)$.

Tabela 9. Densidade populacional de perfilhos pré-pastejo em seis ciclos de pastejo

\begin{tabular}{|c|c|c|c|c|c|c|c|c|}
\hline \multirow[b]{2}{*}{ Capins } & \multicolumn{6}{|c|}{ Ciclos de Pastejo } & \multirow[b]{2}{*}{ Média } & \multirow[b]{2}{*}{ EPM } \\
\hline & & & \multirow{2}{*}{\multicolumn{2}{|c|}{$\begin{array}{cc}\text { C3 } & \text { C4 } \\
27 / 08 \text { a } & 13 / 11 \text { a } \\
08 / 10 / 02 & 05 / 12 / 02 \\
\text { Perfilhos } m^{-2}\end{array}$}} & $\begin{array}{l}\text { C5 } \\
19 / 12 / 02 \text { a } \\
29 / 01 / 03\end{array}$ & $\begin{array}{c}\mathrm{C6} \\
15 / 02 \mathrm{a} \\
24 / 03 / 03\end{array}$ & & \\
\hline & & & & & & & \multirow[b]{2}{*}{$1306^{a}$} & \multirow[b]{2}{*}{44,39} \\
\hline Arue & $1553^{\mathrm{aB}}$ & $745^{\mathrm{aC}}$ & $684^{\mathrm{aC}}$ & $866^{a C}$ & $1539^{a B}$ & $2450^{\mathrm{aA}}$ & & \\
\hline $\operatorname{Tan} z$ & 592 & $369^{\mathrm{bA}}$ & 486 & $439^{\mathrm{bA}}$ & 518 & 04 & & 44, \\
\hline \multicolumn{9}{|c|}{$\begin{array}{l}{ }^{{ }^{0}} \text { Médias na mesma coluna seguidas da mesma letra minúscula não diferem entre } \\
{ }^{A B} \text { Médias na mesma linha seguidas da mesma letra maiúscula não diferem entre si } \\
\text { EPM: erro padrão da média. }\end{array}$} \\
\hline \multicolumn{9}{|c|}{ O capim-Aruana apresentou maior número de perfilhos $\mathrm{m}^{-2}$ no ciclo de pastejo } \\
\hline \multirow{2}{*}{\multicolumn{9}{|c|}{$\begin{array}{l}\text { C6 (Verão), seguido dos periodos C1 e C4 (outono e início de verão), sendo que o } \\
\text { menor número de perfilhos } \mathrm{m}^{-2} \text { ocorreu nos ciclos } \mathrm{C} 2, \mathrm{C} 3 \text {, e } \mathrm{C} 4 \text { (inverno e primavera). }\end{array}$}} \\
\hline & & & & & & & & \\
\hline \multirow{5}{*}{\multicolumn{9}{|c|}{$\begin{array}{l}\text { Cecato (1993) observou número de perfilhos do capim-Aruana de } 515 \mathrm{~m}^{-2} \text { no periodo } \\
\text { de formação da pastagem (primeira estação de chuvas), } 992 \mathrm{~m}^{-2} \text { na seca subsequente } \\
\text { e } 1.008 \mathrm{~m}^{-2} \text { na segunda estação de chuvas, mas não verificou diferenças no } \\
\text { perfilhamento com a aplicação de zero, } 100 \text { ou } 200 \mathrm{~kg} \mathrm{~N} \mathrm{ha-1.} \mathrm{Já} \mathrm{Benitez} \mathrm{(1993)} \\
\text { encontrou } 917 \text { perfilhos } \mathrm{m}^{-2} \text { para o capim-Aruana com a aplicação de } 75 \mathrm{~kg} \mathrm{~N} \mathrm{ha}^{-1} \text {, que }\end{array}$}} \\
\hline & & & & & & & & \\
\hline & & & & & & & & \\
\hline & & & & & & & & \\
\hline & & & & & & & & \\
\hline & & & & & & & & \\
\hline
\end{tabular}


Zimmer (1999), avaliando o número de perfilhos do capim-Aruana com relação à adubação nitrogenada (zero e $150 \mathrm{~kg} \mathrm{~N} \mathrm{ha}^{-1}$ ), mostrou que na média geral, a adubação nitrogenada resultou em maior número de perfilhos $\left(887 \mathrm{~m}^{-2}\right)$ em relação à testemunha $\left(777 \mathrm{~m}^{-2}\right.$ ) ao longo de 13 ciclos de pastejo, afirmando que o perfilhamento foi maior com a adubação nitrogenada na primeira estação seca, segunda estação de chuvas e segunda estação seca, sendo que nas demais avaliações os valores não diferiram. Nota-se que no presente trabalho o número de perfilhos mensurados para o capimAruana foi maior do que em todos os trabalhos citados anteriormente, pois no presente estudo também foram considerados (contados) os perfilhos aéreos. Carvalho et al. (1999), estudando os capins Aruana e Tanzânia por quatro meses em cabines de crescimento (vasos) sob duas alturas de corte (5 e $15 \mathrm{~cm}$ ), observaram que o capimAruana apresentou maior número de perfilhos do que o capim-Tanzânia devido à sua alta capacidade de perfilhamento nos nós aéreos (grande número de perfilhos aéreos). Esse grande número de perfilhos aéreos do capim-Aruana parece ter um papel importante na rebrotação em algumas estações do ano, mas não necessariamente contribui para maior produção de forragem.

O número de perfilhos $\mathrm{m}^{-2}$ do capim-Tanzânia não diferiu entre os ciclos de pastejo. Em contraste, Carvalho (2002), estudando o capim-Tanzânia em casa-devegetação na Nova Zelândia sob duas alturas de corte, observou maior número de perfilhos durante os meses de novembro / dezembro, assim como Santos (1997) reportou maior densidade populacional de perfilhos para o capim-Tanzânia nessa mesma época, e menor durante a fase de desenvolvimento reprodutivo, mantendo-se relativamente constante no resto do ano.

\subsection{Sistema radicular}

\subsubsection{Massa, comprimento e superfície radiculares no pré-pastejo}

Para massa seca da matéria orgânica (MSMO) de raizes $\left(\mathrm{mg} \mathrm{cm}{ }^{-3}\right.$ de solo), houve interação capins $x$ doses de $N$ (Tabela 10), e diferença $(P<0,10)$ entre capins e ciclos de pastejo (Tabela 11).

Conforme descrito em material e métodos, as amostras foram retiradas ao lado da base de touceiras representativas da área. Segundo estudo realizado na área 
experimental por Carvalho et al. (2003), a área de solo coberta por plantas, na média dos dois capins, foi de $47 \%$. Em virtude disso optou-se por não extrapolar os dados para hectare, evitando assim uma super estimativa de raizes, optando-se por mensurar as raizes para $\mathrm{cm}^{3}$ de solo.

As medidas do sistema radicular pré-pastejo foram feitas com o intuito de observar possiveis diferenças quanto a MSMO, comprimento e superfície do sistema radicular dos capins Aruana e Tanzânia, em função de doses de $\mathrm{N}$ e ciclos de pastejo.

$\mathrm{Na}$ Tabela 10 é mostrada a interação $(P<0,10)$ capins $x$ doses de $N$. Observa-se que o capim-Tanzânia apresentou maior MSMO na dose de $300 \mathrm{~kg} \mathrm{ha}^{-1}$ de $\mathrm{N}$. Já a MSMO do capim-Aruana não diferiu $(p>0,10)$ entre as doses de $N$ estudadas.

Tabela 10. Massa seca da matéria orgânica $\left(\mathrm{mg} \mathrm{cm}^{-3}\right.$ de solo) para os capins Aruana e Tanzânia e doses de $\mathrm{N}\left(150\right.$ e $\left.300 \mathrm{~kg} \mathrm{ha}^{-1}\right)$, médias dos quatro ciclos de pastejo

\section{Doses de $\mathrm{N}\left(\mathrm{kg} \mathrm{ha}^{-1}\right)$}

\begin{tabular}{ccc} 
Capins & $150 \mathrm{~kg} \mathrm{~N}$ & $300 \mathrm{~kg} \mathrm{~N}$ \\
\hline Aruana & $1,2^{\mathrm{aA}}$ & $1,1^{\mathrm{bA}}$ \\
Tanzânia & $1,6^{\mathrm{aA}}$ & $1,8^{\mathrm{aB}}$ \\
\hline${ }^{\mathrm{aB}}$ Médias na mesma coluna seguidas da mesma letra minúscula não diferem entre si $(p>0,10)$.
\end{tabular}

Apesar de os capins não terem diferido $(p>0,10)$ quanto ao acúmulo de forragem (Tabela 7), diferiram quanto à MSMO de raizes, sendo que o capimTanzânia, na média entre capins, doses de $\mathrm{N}$ e ciclos de pastejo, teve maior quantidade de MSMO (1,7 $\mathrm{mg} \mathrm{cm}^{-3}$ de solo) do que o capim-Aruana $\left(1,2 \mathrm{mg} \mathrm{cm}^{-3} \mathrm{de}\right.$ solo), provavelmente devido ao seu maior porte. Isso pôde ser observado visualmente, pois em periodos de seca mais prolongados o capim-Tanzânia demorava mais tempo para mostrar estresse hidrico (enrolamento de folhas).

A maior MSMO observada na dose de $300 \mathrm{~kg} \mathrm{ha}^{-1}$ de $\mathrm{N}$ difere dos resultados obtidos por Cecato et al. (2003), que avaliou o peso seco de raizes do capim-Tanzânia adubado com quatro doses de nitrogênio $\left(50,100,200\right.$ e $400 \mathrm{~kg} \mathrm{ha}^{-1}$ de $\mathrm{N}$, fracionadas em quatro aplicações durante a primavera e verão) no periodo de setembro a maio, 
sob lotação contínua e taxa de lotação variável mantendo altura média do dossel forrageiro em $50 \mathrm{~cm}$. Esses autores reportaram que a produção de $M S$ de raízes foi semelhante entre as doses de $\mathrm{N}$ utilizadas, sendo de 51,50, 47 e $40 \mathrm{mg}$ de raizes / $687 \mathrm{~cm}^{3}$ de solo para as doses de 50,100, 200 e $400 \mathrm{~kg} \mathrm{ha}^{-1}$ de $\mathrm{N}$, respectivamente. Os autores justificaram que os valores semelhantes encontrados para as doses de $\mathrm{N}$ ocorreram pelo manejo feito adequadamente, através da altura média do dossel forrageiro de $50 \mathrm{~cm}$ para todos os tratamentos e elevado índice de área foliar, o que resultou em pesos semelhantes. No entanto, não foi mencionada a profundidade de coleta, apenas o volume de solo coletado. Esse fato, juntamente com o manejo do pastejo adotado, podem ser motivos pelos quais os valores diferiram dos encontrados no presente trabalho.

Tabela 11. Massa de raízes pré-pastejo $\left(\mathrm{mg} \mathrm{cm}^{-3}\right.$ de solo) em quatro ciclos de pastejo para os capins Aruana e Tanzânia, média das doses de $\mathrm{N}$ e capins

\begin{tabular}{|c|c|c|c|c|}
\hline & \multicolumn{4}{|c|}{ Períodos de pastejo } \\
\hline & $\mathrm{C} 1$ & $\mathrm{C} 2$ & C3 & $\mathrm{C} 4$ \\
\hline & $09 / 05$ a 27/06/02 & $04 / 07$ a $21 / 08 / 02$ & $27 / 08$ a 08/10/02 & $19 / 12 / 02$ a $29 / 01 / 03$ \\
\hline Média & $1,2^{6}$ & $1,6^{\mathrm{a}}$ & $1,5^{\mathrm{a}}$ & $1,5^{\mathrm{a}}$ \\
\hline EPM & 0,09 & 0,09 & 0,09 & 0,11 \\
\hline
\end{tabular}

A MSMO do sistema radicular diferiu $(P<0,10)$ entre os ciclos de pastejo (Tabela 11). No $C 1$, equivalente ao outono, a MSMO de raizes foi menor $(P<0,10)$ do que nos outros ciclos avaliados que, por sua vez, não diferiram entre si $(P>0,10)$. Já Pagotto (2001), avaliando o sistema radicular do capim-Tanzânia irrigado, não encontrou diferença entre massa de raizes pré-pastejo entre os periodos de primavera, verão e outono. Tosi (1999), avaliando o sistema radicular do capim-Tanzânia em pastejo em São Carlos (SP), reportou que maior massa de raizes foi observada durante os meses de janeiro e fevereiro (verão).

As variáveis comprimento (Tabela 12) e superfície (Tabela 13) das raizes apresentaram comportamento semelhante, por isso optou-se por discuti-las 
simultaneamente. Ambas as variáveis diferiram $(P<0,10)$ entre capins, doses de $\mathrm{N}$ e ciclos de pastejo, e houve interação capins $x$ doses de $N$, ciclos de pastejo $x$ doses de $\mathrm{N}$, e ciclos de pastejo $x$ capins $x$ doses de $N$. Esta última interação foi a utilizada para mostrar os resultados obtidos (Tabelas 12 e 13).

Tabela 12. Comprimento ( $\mathrm{cm} \mathrm{cm}^{-3}$ de solo) de raizes dos capins Aruana e Tanzânia, em quatro ciclos de pastejo e duas doses de nitrogênio

\begin{tabular}{|c|c|c|c|c|c|c|}
\hline Doses $\mathrm{N}$ & C1 & $\mathrm{C} 2$ & C3 & C4 & Média & EPM \\
\hline \multicolumn{7}{|c|}{ Aruana } \\
\hline $150 \mathrm{~kg} \mathrm{~N}$ & $41,0^{\mathrm{aA}}$ & $84,3^{\mathrm{aA}}$ & $61,7^{\mathrm{aA}}$ & $80,2^{\mathrm{aA}}$ & $66,8^{a}$ & 7,05 \\
\hline $300 \mathrm{~kg} \mathrm{~N}$ & $30,2^{\mathrm{ac}}$ & $102,2^{\mathrm{aA}}$ & $91,4^{\mathrm{aA}}$ & $58,8^{\mathrm{aB}}$ & $70,6^{a}$ & 7,05 \\
\hline Média & $35,6^{\mathrm{C}}$ & $93,8^{A}$ & $76,5^{\mathrm{AB}}$ & $69,5^{\mathrm{B}}$ & & \\
\hline EPM & 6,56 & 12,91 & 17,77 & 14,25 & & \\
\hline \multicolumn{7}{|c|}{ Tanzânia } \\
\hline $150 \mathrm{~kg} \mathrm{~N}$ & $68,7^{\mathrm{aB}}$ & $133,9^{\mathrm{aA}}$ & $96,0^{\mathrm{aB}}$ & $79,8^{\mathrm{bB}}$ & $94,6^{b}$ & 7,05 \\
\hline $300 \mathrm{~kg} \mathrm{~N}$ & $65,7^{\mathrm{ac}}$ & $165,6^{\mathrm{aB}}$ & $125,7^{\mathrm{aB}}$ & $217,8^{\mathrm{aA}}$ & $143,6^{a}$ & 7,05 \\
\hline Média & $67,1^{\mathrm{C}}$ & $149,7^{A}$ & $110,8^{B}$ & $148,8^{A}$ & & \\
\hline EPM & 6,56 & 12,91 & 17,77 & 14,25 & & \\
\hline
\end{tabular}

O comprimento do sistema radicular pré-pastejo diferiu entre capins $(P<0,10)$, com o capim-Tanzânia apresentando maior comprimento $\left(119,1 \mathrm{~cm} \mathrm{~cm}^{-3}\right.$ de solo) do que o capim-Aruana $\left(68,7 \mathrm{~cm} \mathrm{~cm}^{-3}\right.$ de solo). Diferiu também entre doses de $N(P<0,10)$, sendo que a dose de $300 \mathrm{~kg} \mathrm{ha}^{-1}$ de $\mathrm{N}$ contribuiu para maior comprimento do sistema radicular $\left(107,1 \mathrm{~cm} \mathrm{~cm}^{-3}\right.$ de solo) do que a dose de $150 \mathrm{~kg} \mathrm{ha}^{-1} \mathrm{de} \mathrm{N}\left(80,7 \mathrm{~cm} \mathrm{~cm}^{-3}\right.$ de solo). O mesmo aconteceu quanto à superficie do sistema radicular pré-pastejo, com o capim-Tanzânia apresentando maior superfície $(P<0,10)\left(37,4 \mathrm{~cm}^{-2} \mathrm{~cm}^{-3}\right.$ de solo) do que o capim-Aruana $\left(22,0 \mathrm{~cm}^{-2} \mathrm{~cm}^{-3}\right.$ de solo), assim como a dose de $300 \mathrm{~kg} \mathrm{ha}^{-1} \mathrm{de} \mathrm{N}$ contribuiu para maior superficie do sistema radicular $(P<0,10)\left(33,3 \mathrm{~cm}^{-2} \mathrm{~cm}^{-3}\right.$ de solo) do que a dose de $150 \mathrm{~kg} \mathrm{ha}^{-1}$ de $\mathrm{N}\left(26,2 \mathrm{~cm}^{-2} \mathrm{~cm}^{-3}\right.$ de solo). 
Tabela 13. Superfície $\left(\mathrm{cm}^{-2} \mathrm{~cm}^{-3}\right.$ de solo) de raizes dos capins Aruana e Tanzânia, em quatro ciclos de pastejo e duas doses de nitrogênio

\begin{tabular}{|c|c|c|c|c|c|c|}
\hline Doses N & C1 & $\mathrm{C} 2$ & $\mathrm{C} 3$ & C4 & Média & EPM \\
\hline \multicolumn{7}{|c|}{ Aruana } \\
\hline $150 \mathrm{~kg} \mathrm{~N}$ & $16,0^{\mathrm{aA}}$ & $25,7^{\mathrm{aA}}$ & $19,5^{\mathrm{aA}}$ & $24,5^{\mathrm{aA}}$ & $21,4^{a}$ & 2,89 \\
\hline $300 \mathrm{~kg} \mathrm{~N}$ & $11,4^{\mathrm{aC}}$ & $33,1^{\mathrm{aA}}$ & $28,1^{\mathrm{AAB}}$ & $19,7^{\mathrm{aBC}}$ & $22,6^{a}$ & 2,89 \\
\hline Média & $13,7^{C}$ & $29,4^{\mathrm{A}}$ & $23,8^{A B}$ & $21,2^{B}$ & & \\
\hline EPM & 2,35 & 3,56 & 5,33 & 4,53 & & \\
\hline \multicolumn{7}{|c|}{ Tanzânia } \\
\hline $150 \mathrm{~kg} \mathrm{~N}$ & $24,8^{\mathrm{aA}}$ & $39,2^{\mathrm{aA}}$ & $33,8^{\mathrm{aA}}$ & $26,2^{\mathrm{bA}}$ & $31,0^{\mathrm{b}}$ & 2,89 \\
\hline $300 \mathrm{~kg} \mathrm{~N}$ & $23,3^{a c}$ & $49,4^{\mathrm{aB}}$ & $37,8^{\mathrm{aB}}$ & $65,2^{\text {aA }}$ & $43,9^{\mathrm{a}}$ & 2,89 \\
\hline Média & $24,1^{\mathrm{C}}$ & $44,3^{A}$ & $35,8^{B}$ & $45,7^{A}$ & & \\
\hline EPM & 2,35 & 3,56 & 5,33 & 4,54 & & \\
\hline
\end{tabular}

A análise da Tabelas 12 e 13 revela que o comprimento e a superfície do sistema radicular do capim-Aruana não diferiram $(P>0,10)$ entre as doses de $N$. $O$ comprimento e superfície do sistema radicular do capim-Aruana não diferiram $(P>0,10)$ entre ciclos de pastejo com a dose de $150 \mathrm{~kg} \mathrm{ha}^{-1}$ de $\mathrm{N}$. No entanto, os valores das variáveis do sistema radicular tiveram alto CV (ao redor de $40 \%$ ), ocasionando situações como esta, em que a diferença entre $\mathrm{C} 2$ e C1, para a dose de $150 \mathrm{~kg} \mathrm{ha}^{-1} \mathrm{de}$ $N$ (Tabela 12), é de aproximadamente $50 \%$, e que, entretanto, não diferiram estatisticamente. Para a dose de $300 \mathrm{~kg} \mathrm{ha}^{-1}$ de $\mathrm{N}$ observa-se que entre os ciclos de pastejo analisados, no $\mathrm{C} 1$ (outono), comprimento e superfície radicular apresentaram os menores valores quando comparados aos outros ciclos de pastejo. Maior comprimento e superfície radiculares foram notados no $\mathrm{C} 2$ e $\mathrm{C} 3$ (inverno e inverno/primavera). Uma possivel explicação para o ocorrido seria que o sistema radicular aumentou em comprimento e superfície nesse ciclos de pastejo devido às condições de baixa precipitação (Figura 1), em busca de água e nutrientes, além de ser um período de menor acúmulo de forragem (Tabela 7), quando os compostos de 
reserva não estão sendo utilizados para o crescimento da parte aérea, podendo ser utilizados pelo sistema radicular, favorecendo seu crescimento.

O comprimento e a superfície do sistema radicular do capim-Tanzânia diferiram $(P<0,10)$, quando comparadas as doses de $N$, apenas no $C 4$ (verão), quando ambas as variáveis foram superiores na dose de $300 \mathrm{~kg} \mathrm{ha}^{-1}$ de $\mathrm{N}$ (Tabelas 12 e 13). Na dose de $150 \mathrm{~kg} \mathrm{ha}^{-1}$ de $\mathrm{N}$, o comprimento do sistema radicular (Tabela 12) foi maior $(P<0,10)$ no C2 (inverno), não diferindo entre os outros ciclos de pastejo, enquanto a superfície (Tabela 13) não variou entre eles. Para a dose de $300 \mathrm{~kg} \mathrm{ha}^{-1}$ de $\mathrm{N}$, o comprimento e a superficie do sistema radicular apresentaram comportamento semelhante. Observa-se que para essa dose de $\mathrm{N}$, no $\mathrm{C} 4$ (verão) o comprimento e superfície do sistema radicular foram maiores, iguais no $\mathrm{C} 2$ e C3 (inverno e inverno/primavera) e menores no C1 (outono). Esse comportamento difere do reportado por Pagotto (2001), que estudando o sistema radicular do capim-Tanzânia irrigado não encontrou diferenças entre comprimento e superficie de raizes para as estações de primavera, verão e outono, provavelmente em virtude da irrigação.

Observa-se que o comportamento dos dois capins foi diferente quanto ao comprimento e superfície do sistema radicular ao longo dos ciclos de pastejo, sendo que o capim-Aruana apresentou essas variáveis superiores no C2 e C3 (inverno e inverno/primavera), enquanto para o capim-Tanzânia isso ocorreu no C4 (verão) (Tabelas 12 e 13), mostrando mais uma diferença morfofisiológica entre eles. Para o capim-Tanzânia, maior comprimento e superfície radicular foram importantes no periodo de maior crescimento da parte aérea, provavelmente para suprir a maior necessidade de água e nutrientes para seu crescimento. Já o maior comprimento e superfície radiculares do capim-Aruana na época seca do ano podem estar relacionados com sua menor sazonalidade de produção da parte aérea (39\% de sua produção anual no periodo do "inverno", reportada no item 4.1.2), pois o sistema radicular cresce mais em busca de água e nutrientes nesse periodo.

A característica que ambos os capins apresentaram em comum foi menor MSMO, comprimento e superfície do sistema radicular no $\mathrm{C} 1$ (outono).

\subsubsection{Crescimento do sistema radicular pós-pastejo}


Por meio da quantificação do desenvolvimento das raizes em buracos preenchidos com areia ("refilled cores"), foi possivel analisar a dinâmica de crescimento do sistema radicular pós-pastejo, conforme proposto por Matthew (1992).

$\mathrm{Na}$ Figura 3 observa-se os resultados de crescimento de raizes quanto a

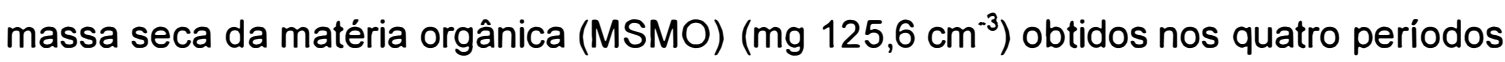
de rebrotação e nas quatro idades de crescimento pós-pastejo (médias de capins e doses de $N)$. Houve diferença entre períodos de rebrotação $(P<0,10)$ e idades de crescimento pós-pastejo $(P<0,10)$, assim como houve interação periodos de rebrotação $x$ idades de crescimento pós-pastejo $(P<0,10)$. Não foram observadas diferenças entre capins $(P>0,10)$ e entre doses de $N(P>0,10)$, e não houve interação capins $\times$ doses de $\mathrm{N}$.

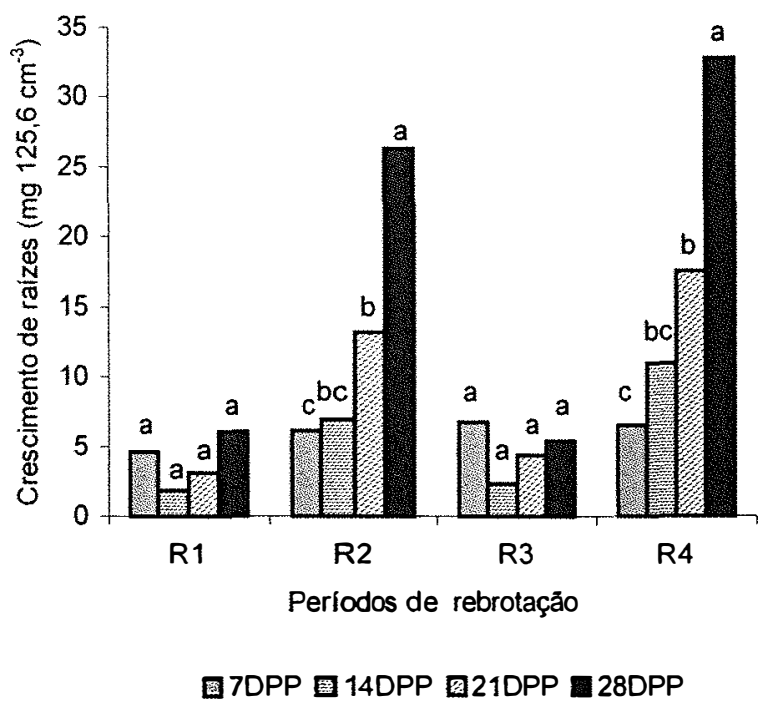

Figura 3- Massa de raízes pós-pastejo em quatro períodos de rebrotação (R1: 16/05 a 04/07/02; R2: $11 / 07$ a 27/08/02; R3: 02/09 a 17/10/02; R4: 26/12/02 a 28/03/03) e em quatro idades de crescimento pós-pastejo $(7,14,21$ e 28DPP: dias pós-pastejo)

Pode-se observar que os períodos em que houve maior crescimento de raizes foram o R2 e o R4, equivalentes às amostragens efetuadas nas estações de inverno e verão, e que nos períodos R1 e R3 (outono e transição entre inverno e primavera) não houve variação de crescimento de raízes $(P>0,10)$. $O$ crescimento aumentou do outono para o inverno, caiu com a chegada da primavera e atingiu seu pico no verão. 
Matthew (1992), estudando azevém perene sob pastejo na Nova Zelândia, observou que a MSMO de raizes aumentou durante o periodo seco (verão neozelandês). No caso do presente experimento, também foi encontrado crescimento acentuado no período seco (R2 - inverno), podendo-se concluir que a escassez de água é fator que pode condicionar crescimento de raizes.

Pelos dados obtidos nas idades de crescimento pós-pastejo, pode-se observar a dinâmica cronológica de desenvolvimento radicular para 7, 14, 21 e 28 dias. Nos períodos de avaliação R1 e R3 (outono e inverno/primavera), não houve diferença para MSMO de raízes $(P>0,10)$ entre as idades de crescimento, coincidindo com os periodos em que houve menor crescimento do sistema radicular, o que pode ser visualizado pelas médias das quatro idades de crescimento de cada período de rebrotação (Apêndice - Tabela 6). Já nos períodos R2 e R4 (inverno e verão) pode-se observar diferenças para a massa de raizes $(P<0,10)$ entre as idades de crescimento, sendo que aos 7 e 14 dias a massa de raizes foi semelhante, assim como aos 14 e 21 dias, e se acentuou dos 14 aos 28 dias pós-pastejo. As médias gerais da massa de raizes para as idades de crescimento são mostradas no Apêndice (Tabela 7).

O comprimento de raizes (Figura 4 ) diferiu $(P<0,10)$ para doses de $\mathrm{N}$ e periodos de rebrotação, assim como houve interação $(P<0,10)$ doses de nitrogênio $x$ periodos de rebrotação, e períodos de rebrotação x idades de crescimento pós-pastejo. Mas não foram observadas diferenças entre capins e nem interação entre capins e doses de $N$

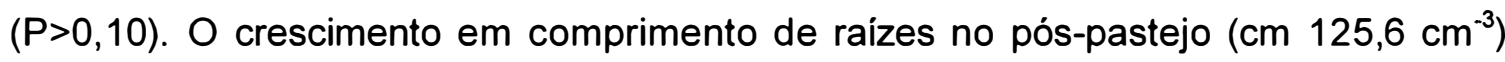
(Figura 4) apresentou comportamento semelhante a MSMO dessas mesmas raizes (Figura 3), mostrando que ambas variáveis podem fornecer subsidios para avaliação do comportamento do sistema radicular.

Os períodos de rebrotação em que mensurou-se maior crescimento de raízes foram os de inverno e verão (R2 e R4), à semelhança do que ocorreu quanto à variável MSMO, com a diferença de que o crescimento foi maior no periodo de inverno, seguido pelo de verão. Nos períodos R1 e R3, equivalentes ao outono e inverno/primavera, foi constatado menor crescimento do sistema radicular. Observando-se as médias entre períodos de rebrotação (Apêndice - Tabela 6), nota-se que o comprimento de raízes medido no outono foi menor do que o atingido no inverno, quando foi máximo. Aumentou muito pouco na primavera e retomou seu crescimento no verão. 


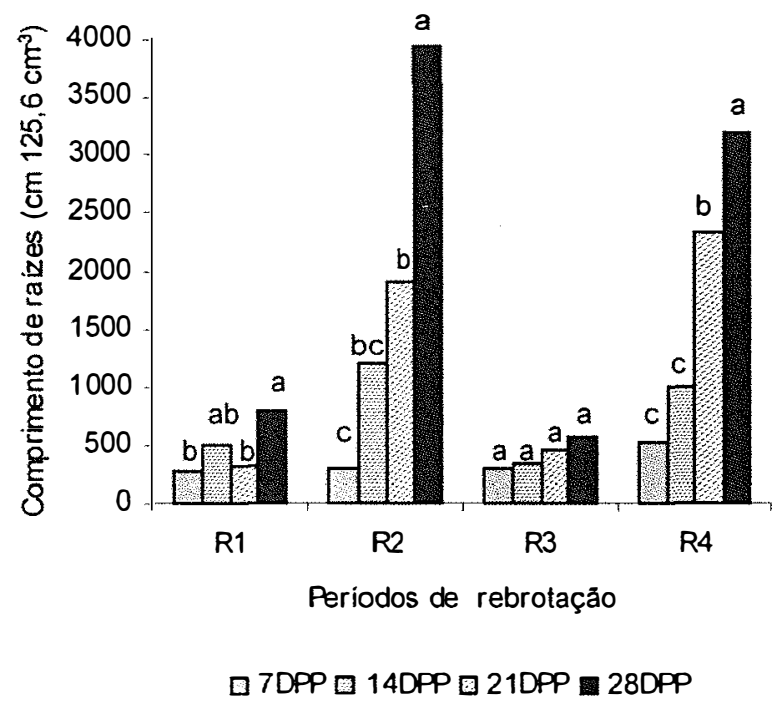

Figura 4 - Comprimento de raízes pós-pastejo em quatro períodos de rebrotação (R1: 16/05 a 04/07/02; R2: 11/07 a 27/08/02; R3: 02/09 a 17/10/02; R4: 26/12/02 a 28/03/03) e em quatro idades de crescimento pós-pastejo $(7,14,21$ e 28 DPP: dias pós-pastejo)

Com as idades de crescimento pós-pastejo, pode-se observar 0 crescimento em comprimento das raizes aos 7, 14, 21 e 28 dias. No R1 (outono), o comprimento aos 7,14 e 21 dias pós-pastejo não diferiram entre si $(P>0,10)$, sendo que aos 14 e 28 dias foram semelhantes $(P<0,10)$ (Figura 4). Já no R3 (inverno/primavera), à semelhança do ocorrido com MSMO (Figura 3 ), as avaliações nas idades de crescimento não diferiram entre si $(P>0,10)$.

Nos periodos de rebrotação R2 e R4 (inverno e verão) pôde-se observar diferenças para comprimento de raizes $(P<0,10)$ entre as idades de crescimento. Para ambos os periodos de rebrotação, as avaliações aos 7 e 14 dias pós-pastejo não diferiram entre si $(P>0,10)$. No $R 2$, o comprimento das raizes aos 14 e 21 dias póspastejo não foi diferente $(P>0,10)$, mas diferiu acentuadamente do comprimento aos 28 dias, mostrando retomada de crescimento das raizes. No R4, os crescimentos em comprimento aos 7 e 14 dias pós-pastejo não diferiram entre si $(P>0,10)$, mas 0 comprimento aos 14 dias diferiu $(P<0,10)$ daquele aos 21 e 28 dias pós-pastejo, indicando que o comprimento radicular aumentou acentuadamente a partir dos 14 dias pós-pastejo no verão. Os compostos de reserva (carboidratos não estruturais e 
compostos nitrogenados) que são acumulados principalmente na base do colmo e raizes das plantas (Donaghy \& Fulkerson, 1998), têm sua concentração reduzida por ocasião da desfolha, indicando que a rebrota da planta forrageira é dependente desses compostos de reserva até que a área foliar formada seja suficiente para atender as necessidades do perfilho, isto é, o perfilho em rebrota passa do estágio de dreno para fonte metabólica (Pagotto, 2001). Esse mesmo autor, estudando o crescimento de raizes do capim-Tanzânia irrigado, afirmou que a planta fica sob condição de estresse até pelo menos duas semanas após ser colhida, independente do manejo imposto. Comportamento semelhante foi encontrado no presente experimento, podendo-se inferir que os compostos de reserva têm importante influência sobre o crescimento do sistema radicular pós-desfolha.

$\mathrm{Na}$ Figura 5 pode-se observar os valores de comprimento de raizes em função das doses de $\mathrm{N}$ e periodos de rebrotação, na média dos dois capins.

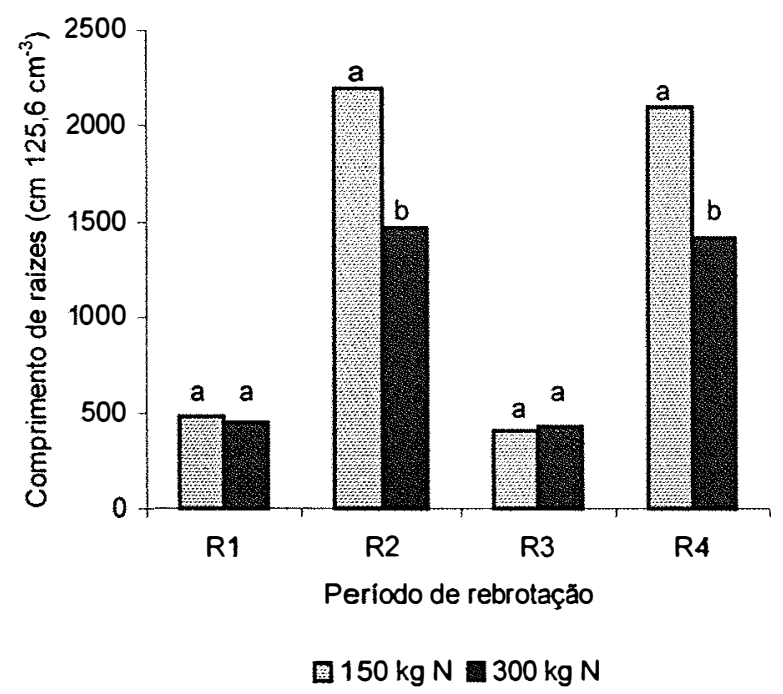

Figura 5 - Comprimento de raizes pós-pastejo em quatro periodos de rebrotação (R1: 16/05 a 04/07/02; R2: 11/07 a 27/08/02; R3: 02/09 a 17/10/02; R4: 26/12/02 a 28/03/03) e duas doses de nitrogênio (150 e $300 \mathrm{~kg} \mathrm{ha}^{-1}$ de N)

No R1 (outono) e R3 (inverno/primavera) não houve efeito das doses de $\mathrm{N}$ no comprimento das raízes $(P>0,10)$, coincidindo com os períodos de menor crescimento do sistema radicular para as variáveis massa, comprimento e superfície de raizes (Apêndice - Tabela 6). Mas nos períodos de rebrotação R2 e R4 (inverno e verão), que 
foram os que apresentaram maior crescimento do sistema radicular, pode-se observar efeito $(P<0,10)$ das doses de nitrogênio. $A$ dose de $150 \mathrm{~kg} \mathrm{ha}^{-1}$ de $\mathrm{N}$ promoveu maior crescimento em comprimento do sistema radicular.

Pela análise da Figura 6 pode-se observar os resultados obtidos quanto ao crescimento em superficie do sistema radicular $\left(\mathrm{cm}^{-2} 125,6 \mathrm{~cm}^{-3}\right)$ nos quatro períodos de rebrotação avaliados e nas idades de crescimento pós-pastejo. Houve diferença $(P<0,10)$ para doses de $N$, periodos de rebrotação e idades de crescimento póspastejo, assim como interação $(P<0,10)$ períodos de rebrotação $x$ idades de crescimento pós-pastejo. Não foram observadas diferenças entre os capins e nem interação capins $x$ doses de $N(P>0,10)$.

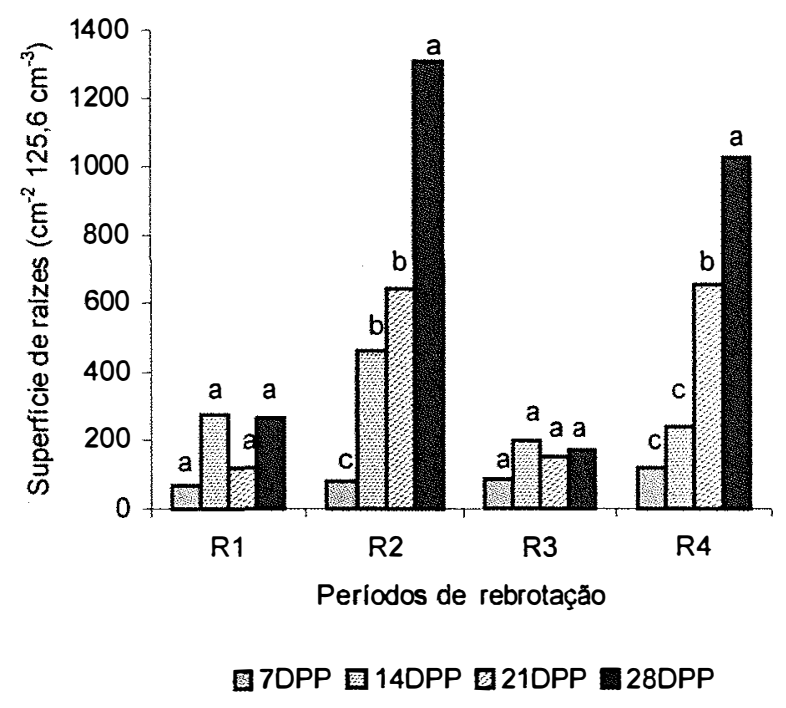

Figura 6 - Superfície de raízes pós-pastejo em (a) quatro períodos de rebrotação (R1: 16/05 a 04/07/02; R2: 11/07 a 27/08/02; R3: 02/09 a 17/10/02; R4: 26/12/02 a 28/03/03) e em (b) quatro idades de crescimento pós-pastejo $(7,14,21$ e 28 DPP: dias pós-pastejo)

Os periodos de rebrotação que apresentaram maior aumento da superfície do sistema radicular foram o R2 e o R4, equivalentes às estações de inverno e verão, enquanto que nos periodos R1 e R3 (outono e inverno/primavera) não houve variação na superfície de raizes. Observa-se que no outono (R1) o crescimento em superfície radicular foi pequeno, aumentou no inverno (R2), cresceu pouco novamente no inverno/primavera (R3), e teve retomado seu crescimento no verão (R4). 
Aparentemente a planta já investiu seus compostos de reserva no crescimento de raízes durante o periodo de inverno $(\mathrm{R} 2)$ e, na primavera, sob condições climáticas favoráveis a seu crescimento, o crescimento da parte aérea foi priorizado (Tabela 7).

Nos periodos de rebrotação R1 e R3 a superficie de raizes não diferiu entre as idades de crescimento pós-pastejo. Aos 14 dias a superfície radicular foi superior àquela da avaliação aos 7 dias no R2 (inverno), mas não diferiu $(P>0,10)$ no R4 (verão). Já a avaliação aos 21 dias mostrou maior crescimento da superficie radicular $(P<0,10)$ no $R 2$ e $R 4$, e um crescimento também significativo $(P<0,10)$ na avaliação feita aos 28 dias pós-pastejo.

$\mathrm{Na}$ Tabela 6 do Apêndice pode-se observar as médias de crescimento em superfície do sistema radicular, que foram semelhantes $(P>0,10)$ entre R1 e R3, e entre R2 e R4, e na Tabela 7 do apêndice nota-se que o crescimento em superfície do sistema radicular foi menor $(P<0,10)$ na avaliação feita 7 dias pós-pastejo, não diferiu aos 14 e 21 dias, e foi maior 28 dias pós-pastejo.

Na Figura 7 observa-se o crescimento em superfície radicular em função das doses de $\mathrm{N}$ e períodos de rebrotação, na média dos dois capins.

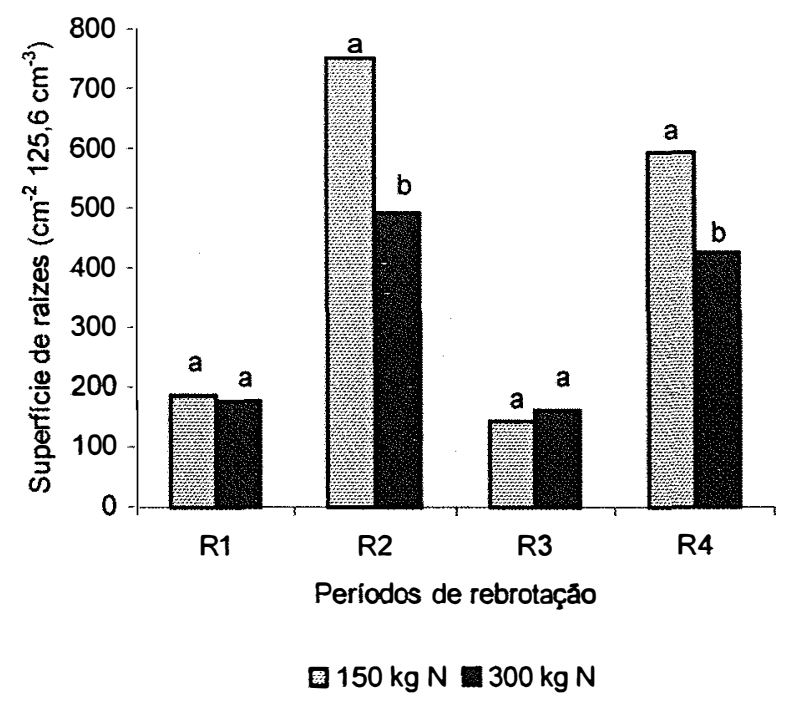

Figura 7 - Superfície de raízes pós-pastejo em quatro periodos de rebrotação (R1: 16/05 a 04/07/02; R2: 11/07 a 27/08/02; R3: 02/09 a 17/10/02; R4: 26/12/02 a 28/03/03) e duas doses de nitrogênio (150 e $300 \mathrm{~kg} \mathrm{ha}^{-1} \mathrm{de} \mathrm{N}$ ) 
Esses resultados estão de acordo com a afirmação feita por Bosemark (1954), de que a relação inversa entre suprimento de nitrogênio e desenvolvimento de raízes é um fenômeno bem conhecido, sendo que menores doses de $\mathrm{N}$ produzem raizes mais longas, enquanto que com o aumento do suprimento de $\mathrm{N}$ as raizes crescem menos. Uma possivel explicação para esse comportamento, segundo Lemaire (1997), é que plantas crescendo em condições de baixa disponibilidade de $\mathrm{N}$, e portanto com reduzida atividade meristemática da parte aérea, alocam maior proporção de produtos da fotossintese para o sistema radicular. Confirmando esse comportamento, Corsi et al. (2001) afirmaram que a estratégia da planta forrageira que rebrota em ambientes com baixa disponibilidade de $\mathrm{N}$ seria a de minimizar o impacto da desfolhação sobre o sistema radicular, uma vez que a baixa atividade meristemática nessas situações, resultado da falta de $\mathrm{N}$ no sistema, limita o rápido desenvolvimento da parte aérea e, desse modo, a retomada do balanço positivo de carbono. Assim, o suprimento de $\mathrm{N}$ para a parte aérea fica na dependência de um sistema radicular mais desenvolvido e capaz de explorar melhor o meio edáfico. Baligar (1998), estudando o crescimento do sistema radicular de trigo, observou que a massa de raizes foi menos afetada pela variação no suprimento de $\mathrm{N}$ do que o comprimento (como no presente trabalho), e que altas doses de $\mathrm{N}$ reduziram o crescimento em comprimento das raizes.

Em contrapartida, esses resultados diferem daqueles obtidos por Singh (1996), que conduziu experimento durante quatro anos para avaliar o efeito do uso de fertilizante nitrogenado em caracteristicas do sistema radicular, e concluiu que a aplicação de nitrogênio aumentou o comprimento radicular até a dose de $200 \mathrm{~kg} \mathrm{ha}^{-1}$ de $\mathrm{N}$ para Panicum maximum Jacq. cv. Makueni.

O sistema radicular dos dois capins (Aruana e Tanzânia) seguiu padrões de crescimento semelhantes nas avaliações de MSMO, comprimento e superficie radicular. Uma possivel explicação para esse comportamento seria a falta de água no solo durante o período seco devido à pouca precipitação (junho/julho - Figura 1), forçando o sistema radicular a crescer em busca de água, aliada a um periodo de pouco crescimento da parte aérea, quando não estão sendo utilizadas reservas para a rebrotação, e que portanto podem ser utilizadas para promover maior crescimento do sistema radicular. Portanto, essa parece ser uma maneira eficiente para que haja maior exploração do solo pelo sistema radicular e, consequentemente, maior capacidade para absorção de água e nutrientes durante o periodo seco. Essa hipótese é reforçada 
pelos resultados obtidos por Pagotto (2001), que não encontrou diferença entre épocas do ano para as variáveis massa, comprimento e superfície de raízes, provavelmente pelo fato de ter trabalhado com o capim-Tanzânia irrigado.

O crescimento expressivo do sistema radicular no verão pode ter sido devido ao maior crescimento da parte aérea (Tabela 7). Como a parte aérea depende das raízes para suprimento de água e minerais, e o sistema radicular depende da parte aérea para suprimento de fotoassimilados, há uma estreita relação entre ambos os processos (Brouwer, 1962). Com o maior crescimento da parte aérea nesse período, devido às condições favoráveis de temperatura e precipitação, aumentou a necessidade de suprimento de nutrientes do solo pelo sistema radicular que, por sua vez, aumentou seu crescimento em busca dos mesmos, tendo sido favorecido pela maior quantidade de fotoassimilados produzidos pela parte aérea.

Observa-se que o crescimento radicular é lento após o pastejo, mas crescente com o aumento das idades de avaliação. Resultados semelhantes foram encontrados por Donaghy \& Fulkerson (1998), que reportaram que plantas de azevém perene cessavam o crescimento radicular após desfolhação no sentido de refazer nova área foliar (rebrotação), retomando seu crescimento a seguir. Também Pagotto (2001), com capim-Tanzânia irrigado, reportou que não houve crescimento radicular nos 3 primeiros dias pós-pastejo, tendo este sido mais intenso entre 12 e 30 dias pós-pastejo, nas condições de seu experimento (diferentes residuos pós-pastejo e irrigação). 


\section{CONCLUSÕES}

- O fator que dominou o comportamento do sistema radicular dos capins Aruana e Tanzânia foram as variações sazonais, o que reflete influências que estão fora do controle do produtor, pois entre os fatores que afetam 0 crescimento $e$ desenvolvimento das plantas, apenas nutrientes e água no solo podem ser manipulados dentro de certos limites econômicos.

- Devem ser tomados maiores cuidados para com o manejo do pastejo durante o periodo de outono, para que o crescimento do sistema radicular não seja prejudicado.

- O período de transição entre inverno e primavera pode ser considerado o mais crítico em termos do manejo do pastejo, podendo-se inferir que esse é um periodo em que o manejo da parte aérea não deve ser muito drástico, para que não haja comprometimento do sistema radicular, assegurando a perenidade da planta forrageira na pastagem.

- O presente estudo forneceu evidências de que há um sistema integrado de funcionamento entre parte aérea e sistema radicular. No entanto, mais estudos devem ser realizados quanto à atividade de raízes para se conhecer o significado efetivo desse comportamento e quais as relações com a perenidade da planta forrageira no sistema de produção.

- Práticas de manejo do pastejo devem ser baseadas em metas claras e objetivas. 


\section{REFERÊNCIAS BIBLIOGRÁFICAS}

ANGHINONI, I.; MEURES, E.J. In: WORKSHOP SOBRE SISTEMA RADICULAR. Metodologias e estudo de casos. Aracaju, 1999. Anais. Aracaju: EMBRAPA Tabuleiros Costeiros, 1999. 300p.

BALIGAR, V.C.; FAGERIA, N.K. ELRASHIDI, M.A. Toxitity and nutrient constraints on root growth. Hort Science, v.33, n.6, p.960-965, 1998.

BARKER, D.J.; ZHANG, D.M.; MACKAY, A.D. Root distribution in a low fertility hill country sward grazed by sheep. New Zealand Journal of Experimental Agriculture, v.16, p.73-76, 1988.

BENITEZ, M.H. Influência do manejo sobre a produção e qualidade do capim-Aruana (Panicum maximum Jacq. CV. Aruana) colhido em três estratos verticais. Jaboticabal, 1993, 68p. (Trabalho de Graduação). Faculdade de Ciências Agrárias e Veterinárias, Universidade Estadual Paulista.

BLOOM, A.J. Crop acquisition of ammonium and nitrate. In: BOOTE, K.J.; BENENTT, J.M.; SINCLAIR, T.R. et al. (Ed.) Physiology and determination of crop yield. Madison: ASA; CSSA; SSSA, 1994. p.303-309.

BOGDAN, A.V. Tropical pasture and fodder plants. London: Longman, 1977, 475p. BONO, J.A.; MACEDO, M.C.M.; EUCLIDES, V.B.P. Biomassa e área do sistema radicular e resistência do solo à penetração em pastagens de Panicum maximum Jacq. sob pastejo rotacionado. (compact disc) In: REUNIÃO ANUAL DA SOCIEDADE BRASILEIRA DE ZOOTECNIA, 37. , Viçosa, 2000. Anais. Viçosa: SBZ, 2000.

BOSEMARK, N.O. The influence of nitrogen on root development. Physiologia Plantarum, v.7, p.497-502, 1954.

BOUMA, T.J.; NIELSEN, K.L.; KOUTSTAAL, B. Sample preparation and scanning protocol for computerised analysis of root length and diameter. Plant and Soil, v.218, p.185-196, 2000. 
BRASIL, F.C.; STOCCO, F.C.; PESSANHA, A.L.; SOUTO, R.L.; ZONTA, E.; ROSSELO, R.O.P. Distribuição e variação temporal de características radiculares de Brachiaria humidicola em um Planossolo. (compact disc) In: REUNIÃO ANUAL DA SOCIEDADE BRASILEIRA DE ZOOTECNIA, 37., Viçosa, 2000. Anais. Viçosa: SBZ, 2000.

BRÂNCIO, P.A.; JÚNIOR, D.N.; EUCLIDES, V.P.B.; REGAZZI, A.J.R.; ALMEIDA, R.G.; FONSECA, D.M. Avaliação de três cultivares de Panicum maximum Jacq. sob pastejo. 1 - Disponibilidade de forragem, altura e profundidade pastejada. (compact disc) In: REUNIÃO ANUAL DA SOCIEDADE BRASILEIRA DE ZOOTECNIA, 37., Viçosa, 2000. Anais. Viçosa: SBZ, 2000.

BROUWER, R. Nutritive influences on the distribution of dry matter in the plant. Netherlands Journal of Agricultural Science, v.10, n.5, p.399-408, 1962.

CARVALHO, D.D. Leaf morphogenesis and tillering behaviour in single plants and simulates swards of Guinea Grass (Panicum maximum Jacq.) cultivars. Palmerston North, 2002, 186p. Thesis (PhD) - Massey University, New Zealand.

CARVALHO, D.D.; MATTHEW, C.; BARIONI, L.G. Participação da matéria seca e perfilhamento em três cultivares de Panicum maximum Jacq. submetidos a dois niveis de defolhação. (compact disc) In: REUNIÃO ANUAL DA SOCIEDADE BRASILEIRA DE ZOOTECNIA, 36., Porto Alegre, 1999. Anais. Porto Alegre: SBZ, 1999.

CARVALHO, D.D.; PAGANO, A.A.G.; FIGUEIRAS, J.F.; MELLACE, E.M.; BLANCO, O.H.N. Cobertura de solo e tamanho de touceiras em pastagens de capim aruana e tanzânia. (compact disc) In: REUNIÃO ANUAL DA SOCIEDADE BRASILEIRA DE ZOOTECNIA, 40., Santa Maria, 2003. Anais. Santa Maria: SBZ, 2003.

CARVALHO, M.C.S. Práticas de recuperação de uma pastagem degradada e seus impactos em atributos físicos, químicos e microbiológicos do solo. Piracicaba, 1999., 103p. Tese (Doutorado) - Escola Superior de Agricultura "Luiz de Queiroz", Universidade de São Paulo.

CECATO, U. Influência da frequência de corte, de niveis e formas de aplicação de nitrogênio sobre a produção, a composição bromatológica e algumas caracteristicas da rebrota do capim-Aruana (Panicum maximum Jacq. cv. Aruana). Jaboticabal, 1993. 112p. Tese (Doutorado) - Faculdade de Ciências Agrárias e Veterinárias, Universidade Estadual Paulista. 
CECATO, U.; FAVORETTO, V.; MALHEIROS, E.B. Frequências de corte, niveis e formas de aplicação de nitrogênio sobre a composição bromatológica de capimAruana (Panicum maximum Jacq. cv. Aruana). Revista UNIMAR, v.16, n.3, p.277291, 1994.

CECATO, U.; HERLING, V.R.; BRAGA, L.M.; RODRIGUES, A.M.; GALBEIRO, S.; FAKIR, G.M.; NETO, M.C.D. Carboidratos, nitrogênio total e peso de raizes em capim-tanzânia (Panicum maximum Jacq, cv. Tanzânia) adubado com diferentes doses de nitrogênio sob pastejo. (compact disc) In: REUNIÃO ANUAL DA SOCIEDADE BRASILEIRA DE ZOOTECNIA, 40., Santa Maria, 2003. Anais. Santa Maria: SBZ, 2003.

CECATO, U.; BARBOSA, M.A.A.F.; SAKAGUTI, E.S.; DAMASCENO, J.C.; SUZUKI, E.; MEURER, F. Avaliação de cultivares de Panicum maximum Jacq. In: REUNIÃO ANUAL DA SOCIEDADE BRASILEIRA DE ZOOTECNIA, 34., Fortaleza, 1996. Anais. Fortaleza: SBZ, 1996. p.109-111.

CORSI, M. Adubação nitrogenada das pastagens. In: PEIXOTO, A.M.; MOURA, J.C.; FARIA, V.P. (Ed.). Pastagens: fundamentos da exploração racional. 2 ed. Piracicaba: FEALQ, 1994. p.121-153.

CORSI, M.; NASCIMENTO JÚNIOR, D. Princípios de fisiologia e morfologia de plantas forrageiras aplicados ao manejo das pastagens. In: PEIXOTO, A.M.; MOURA, J.C.; FARIA, V.P. (Ed.). Pastagens, fundamentos da exploração racional. Piracicaba: FEALQ, 1994. p.15-47.

CORSI, M.; MARTHA JUNIOR, G.B.; PAGOTTO. D.S. Sistema radicular: dinâmica e resposta a regimes de desfolha. In: Mattos, W.R.S. (Ed.) A produção animal na visão dos brasileiros. Sociedade Brasileira de Zootecnia. Piracicaba: FEALQ, 2001. p.838-852.

DA COSTA, N.A.; CORSI, M.; DE FARIA, V.P. Efeito da altura e intervalo de cortes sobre a produção de massa seca aérea e peso da matéria orgânica do sistema radicular do capim-Andropogon (Andropogon gayanus, Kunth). O Solo. v.75, n.2, p.5-10, 1983.

DA SILVA, S.C. Características morfo-fisiológicas e respostas funcionais de plantas forrageiras e animais submetidos a pastejo: desenvolvimento de uma linha de pesquisa. Piracicaba, 2002. 457p. Tese (Livre docência) - Escola Superior de Agricultura "Luiz de Queiroz", Universidade de São Paulo. 
DA SILVA, S.C.; PEDREIRA, C.G.S. Princípios de ecologia aplicados ao manejo da pastagem. In: SIMPÓSIO SOBRE ECOSSISTEMA DE PASTAGENS, 3., Jaboticabal, 1997. Anais. Jaboticabal: FUNEP, 1997. p.1-62.

DEINUM, B. Root mass of swards in different grazing systems. Netherlands Journal of Agricultural Science, v.33, p.377-384, 1985.

DONAGHY, D.J.; FULKERSON, W.J. Priority for allocation of water soluble carbohydrate reserves during regrowth of Lollium perenne. Grass and Forage Science, v.53, p.211-218, 1998.

EMPRESA BRASILEIRA DE PESQUISA AGROPECUÁRIA. Sistema brasileiro de classificação de solos. Serviço Nacional de Levantamento e Conservação de Solos. Brasília: EMBRAPA, produção de informação, 1999, 412p.

EUCLIDES, V.P.B.; MACEDO, M.C.M.; VALÉRIO, J.R. et al. Cultivar Massai (Panicum maximum) a new forage option: adaptability and productivity. (compact disc) In: REUNIÃO ANUAL DA SOCIEDADE BRASILEIRA DE ZOOTECNIA, 37., Viçosa, 2000. Anais. Viçosa: SBZ.

FAVORETTO. V.; REIS, R.A.; VIEIRA, P.F.; MALHEIROS, E.B. Efeito da adubação nitrogenada ou de leguminosas no ganho de peso vivo de bovinos em pastagens de capim-Colonião. Pesquisa Agropecuária Brasileira, v.20, n.4, p.475-482, 1985.

FORNI, S.; MICHEL FILHO, I.C. FAVORETTO, V. MALHEIROS, E.B. Efeito de estratégias de adubação com NPK sobre produção, qualidade e estrutura das cultivares Tanzânia e Mombaça de Panicum maximum Jacq. (compact disc) In: REUNIÃO ANUAL DA SOCIEDADE BRASILEIRA DE ZOOTECNIA, 37., Viçosa, 2000. Anais. Viçosa: SBZ, 2000.

GALBEIRO, S.; CECATO, U.; RODRIGUES, A.M.; CANTO, M.W.; SANTOS, G.T.; JUNIOR, J.A.; FAKIR, G.M.; GONÇALVES, G.P. Estudos de características morfológicas e densidade populacional de perfilhos do capim-Tanzânia (Panicum maximum Jacq. cv. Tanzânia-1) em diferentes niveis de nitrogênio sob pastejo. (compact disc) In: REUNIÃO ANUAL DA SOCIEDADE BRASILEIRA DE ZOOTECNIA, 39., Recife, 2002. Anais... Recife: SBZ, 2002.

GASTAL, F.; BELANGER, G.; LEMAIRE, G. A model for leaf extension rate of tall fescue in response to nitrogen and temperature. Annais of Botany, v.70, p.437442, 1992. 
GERDES, L. Introdução de uma mistura de três espécies forrageiras de inverno em pastagem irrigada de capim-Aruana. Piracicaba, 2003, 73p. Tese (Doutorado) Escola Superior de Agricultura "Luiz de Queiroz", Universidade de São Paulo.

GIBBS, R. Changes in soil structure under different cropping systems. Lincoln College, 1986, 261p. Thesis (PhD).

GOMIDE, J.A. Formação e utilização de capineira de capim Elefante. In: SIMPÓSIO SOBRE CAPIM-ELEFANTE, Coronel Pacheco, 1990. Anais. Coronel Pacheco: EMBRAPA, CNPGL, 1990. p.59-87.

GRANT, S.A.; BARTHRAM, G.T.; TORVEU, L.; KING, S.; ELSTON, D.A. Comparison fo herbage production under continuous stocking and intermittent grazing. Grass and Forage Science, v.43, n.1, p.29-39, 1988.

GREENWOOD, K.K.; HUTCHINSON, K.J. Root characteristics of temperate pasture in New South Wales after grazing at three stocking rates for 30 years. Grass and Forage Science, v.53, p.120-128, 1998.

GREGORY, P.J. Root growth and activity. In: BOOTE, K.J.; BENNETT, J.M.; SINCLAIR, T.R. et al. (Ed.) Physiology and determination of crop yield. Madison: ASA; CSSA; SSSA, 1994. p.65-93.

HERLING, V.R.; BRAGA, G.J.; LUZ, P.H.C.; OTANI, L. Tobiatã, Tanzânia e Mombaça. In: SIMPÓSIO SOBRE MANEJO DA PASTAGEM: a planta forrageira no sistema de produção, 17., Piracicaba, 2000. Anais. Piracicaba: FEALQ, 2000. p.21-64.

HERLING, V.R.; RODRIGUES, L.R.A.; LUZ, P.H.C. Manejo do pastejo. In: SIMPÓSIO SOBRE MANEJO DA PASTAGEM: planejamento e sistemas de produção em pastagens. 18., Piracicaba, 2001. Anais. Piracicaba: FEALQ, 2001. p.157-192.

HODGSON, J. Grazing management: Science into practice. Essex: Longman Scientific \& Technical, 1990. 203p.

HOPKINS, W.G. Introduction to plant physiology. New York: John Wiley, 1995. 464p.

INSTITUTO DE ZOOTECNIA. Capim Aruana (Panicum maximum cv. Aruana IZ-5). Nova Odessa, SP, 1989. 1v. 
JANK, L. Potencial do gênero Panicum. In: SIMPÓSIO BRASILEIRO DE FORRAGENS E PASTAGENS. Campinas, 1994. Anais. Campinas: CBNA, 1994. p.25-31. JANK, L. Melhoramento e seleção de variedades de Panicum maximum. In: PEIXOTO, A.M.; MOURA, J.C.; FARIA, V.P. (Ed.) SIMPÓSIO SOBRE MANEJO DA PASTAGEM, 12., Piracicaba, 1995. Anais. Piracicaba: FEALQ, 1995. p.21-58.

JANK, L.; COSTA, J.C.G. Avaliação, seleção e lançamento de novas cultivares de gramineas da espécie Panicum maximum. In: ENCONTRO SOBRE PRODUÇÃO DE SEMENTES DE PLANTAS FORRAGEIRAS, 4., São José do Rio Preto, 1990. Anais. São José do Rio Preto: Associação Paulista dos Produtores de Sementes e Mudas, 1990. p.1-15.

JANK , L.; SAVIDAN, Y.; SOUZA, M.T.; COSTA, J.C.G. Avaliação do germoplasma de Panicum maximum introduzido da África. 1. Produção forrageira. Revista da Sociedade Brasileira de Zootecnia, v.23, p.433-440, 1994.

JARVIS, S.C. Nitrogen management and sustainability. In: CHERNEY, J.H.; CHERNEY, D.J.R. (Ed.). Grass for dairy cattle. New Yorker: CAB Publ., 1998. cap.7, p.161-192.

LANGER, R.H.M. How grasses grow. London: Edward Arnold, 1979. 66p.

LEMAIRE, G. The physiology of grass growth under grazing: tissue turn-over. In: SIMPÓSIO INTERNACIONAL SOBRE PRODUÇÃO ANIMAL EM PASTEJO. Viçosa, 1997. Anais. Viçosa: UFV, 1997. p.117-144.

LEMAIRE, G. Ecophysiology of grasslands: Dynamic aspects of forage plant population in grazed swards. In: INTERNATIONAL GRASSLAND CONGRESS, 19., São Pedro, 2001. Proceedings. São Pedro: FEALQ, 2001, p.29-37.

LEMAIRE, G.; CHAPMAN, D. Tissue flows in grazed plant communities. In : HOGSON, J.; ILLIUS, A.W. (Ed.) The ecology and management of grazing systems. Guildford: CAB International, 1996. cap.1, p.3-36.

LIBARDI, P.L.; LIER, Q.J. In: WORKSHOP SOBRE SISTEMA RADICULAR: metodologias e estudo de casos. Aracaju, 1999. Anais. Aracaju: EMBRAPA Tabuleiros Costeiros, 1999. 300p.

LOUAHLIA, S.; LAINÉ, P.; OURRY, A.; BOUCAUD, J. The role or N-remobilization and the uptake of $\mathrm{NH}_{4}{ }^{+}$and $\mathrm{NO}_{3}{ }^{-}$by Lollium perenne $\mathrm{L}$. in laminae growth following defoliation under field conditions. Plant and Soil, v.220, p.175-187, 2000. 
MARTHA JÚNIOR, G.B. Balanço de ${ }^{15} \mathrm{~N}$ e perdas de amônia por volatilização em pastagem de capim-Elefante. Piracicaba, 1999. 75p. Dissertação (Mestrado) Escola Superior de Agricultura "Luiz de Queiroz", Universidade de São Paulo.

MARTHA JÚNIOR, G.B.; VILELA, L. Pastagens no cerrado: baixa produtividade pelo uso limitado de fertilizantes em pastagens. Planaltina: EMBRAPA Cerrados, 2002. 32p. (Documentos, 50).

MATCHES, A.G. Plant response to grazing: a review. Journal Production Agriculture. v.5, p. 1-7, 1992.

MATTA, F.M. In: WORKSHOP SOBRE SISTEMA RADICULAR: metodologias e estudo de casos. Aracaju, 1999. Anais. Aracaju: EMBRAPA Tabuleiros Costeiros, 1999. 300p.

MATTHEW, C. A study of seasonal root and tiller dinamics in swards of perennial ryegrass (Lolium perenne, L). Palmerston North, 1992. 247p. Thesis (Ph.D.). Massey University.

MATTHEW, C.; KEMBALL, W.D. Alocation of carbon-14 to roots of different ages in perennial ryegrass (Lolium perene, L.) (compact disc) In: INTERNATIONAL GRASSLAND CONGRESS, 17., Winnipeg/Saskaton, 1997. Proceedings. Winnipeg/Saskaton: CFC/CSA/CSAS, 1997.

MATTOS, H.B.; WERNER, J.C. Efeitos de nitrogênio mineral e de leguminosas sobre a produção de capim-colonião (Panicum maximum Jacq.). Boletim de Indústria Animal, v.36, n.1, p.147-156, 1979.

MATTSSON, M.; JOHANSSON, E.; LUNDBORG, T.; LARSSOM, M.; LARSSON, C.M. Nitrogen utilization in $\mathrm{N}$-limited barley during vegetative and generative growth. I. growth and nitrate uptake kinetics in vegetative cultures grown at diffet/rent relative addition rates of nitrate-N. Journal of Experimental Botany, v. 42, p.197-205, 1991.

MAZZANTI, A.; LEMAIRE, G.; GASTAL, F. The effect of nitrogen fertilization upon the herbage production of tall fescue swards continuously grazed with sheep. 1. Herbage growth dynamics. Grass and Forage Science, v.49, p.111-120, 1994.

MELLO, A.C.L. Respostas morfofisiológicas do capim-Tanzânia irrigado a intensidade de desfolha sob lotação rotacionada. Piracicaba, 2002. 67p. Tese (Doutorado) Escola Superior de Agricultura "Luiz de Queiroz", Universidade de São Paulo. 
MENEZES, M.J.T.; MARTHA JÚNIOR, G.B.; PENATI, M.A.; QUEIROZ NETO, F.; CORSI, M. Efeito da época de adubação nitrogenada do capim-tanzânia irrigado após a desfolha sobre o peso e número de perfilhos. (compact disc) In: REUNIÃO ANUAL DA SOCIEDADE BRASILEIRA DE ZOOTECNIA, 38., Piracicaba, 2001. Anais. Piracicaba: SBZ, 2001.

MIELNICZUC, J. WORKSHOP SOBRE SISTEMA RADICULAR: metodologias e estudo de casos. Aracaju, 1999. Anais. Aracaju: EMBRAPA Tabuleiros Costeiros, 1999. 300p.

MONTEIRO, F.A. Nutrição mineral e adubação. In: SIMPÓSIO SOBRE MANEJO DA PASTAGEM, 12., Piracicaba, 1995. Anais. Piracicaba: FEALQ, 1995. p.219-244.

NABINGER, C. Manejo das desfolha. In: INOVAÇÕES TECNOLÓGICAS NO MANEJO DE PASTAGENS. 19., Piracicaba: 2002. Anais. Piracicaba: FEALQ, 2002. p.133158.

NABINGER, C.; MEDEIROS, R.B. Produção de sementes de Panicum maximum Jacq. In: O CAPIM COLONIÃO. 12. Piracicaba, 1995. Anais. Piracicaba: FEALQ, 1995. p.59-128.

PAGOTTO, D.S. Comportamento do sistema radicular do capim-Tanzânia (Panicum maximum Jacq.) sob irrigação e submetido a diferentes intensidades de pastejo. Piracicaba, 2001. 51p. Dissertação (Mestrado) - Escola Superior de Agricultura "Luiz de Queiroz", Universidade de São Paulo.

QUEIROZ NETO, F.; MARTHA JUNIOR, G.B.; PENATI, M.A.; CORSI, M.; MENEZES, M.J.T. Impact of increasing nitrogen fertiliser rates upon na irrigated Tanzânia grass pasture. 1. Dry matter yeld. In: INTERNATIONAL GRASSLANDA CONGRESS, 19., São Pedro, 2001. Proceedings. Piracicaba:FEALQ, 2001. p.209-210.

RAIJ, B.V.; CANTARELLA, H.; QUAGGIO, J.A.; FURLANI, A.M.C. (Ed.). Recomendações de adubação e calagem para o Estado de São Paulo. 2. Ed. Campinas: Instituto Agronômico, Fundação IAC, 1996. 258p. (Boletim Técnico, 100). 
RICHARDS, J.H. Physiology of plant recovery from defoliation. In: BAKER, M.J. (Ed). SIR Publishing, Wellington. Grassland for our world 1993. p.46-54.

RODRIGUES, L.R.A.; RODRIGUES, T.J.D. Ecofisiologia de plantas forrageiras. In: CASTRO, P.R.C.; FERREIORA, S.O.; YAMADA, T. ET AL. (Ed.). Ecofisiologia da produção agrícola. Piracicaba: POTAFOS, 1987. p.203-230.

ROSSETO, F.A.A. Desempenho agronômico de pastagens de capim elefante cv. Guaçu (Pennisetum purpureum Schum.) e da capim-Tanzânia (Panicum maximum Jacq.) em sistema de produção de leite. Piracicaba, 2000. 174p. Dissertação (Mestrado) - Escola Superior de Agricultura "Luiz de Queiroz", Universidade de São Paulo.

SANTOS, L.E.; CUNHA, E.A.; BUENO, M.S. Altas lotações nas pastagens: uma técnica viável para ovinos. Nova Odessa, 2001. Instituto de Zootecnia de Nova Odessa, 2001a. 45p.

SANTOS, L.E.; CUNHA, E.A.; BUENO, M.S. Ovinos e o capim Aruana. Revista Criação e Negócios, v.11, p.32-34, 2001 b.

SANTOS, P.M. Estudo de algumas caracterísiticas agronômicas de Panicum maximum (Jacq.) cvs. Tanzânia e Mombaça para estabelecer seu manejo. Piracicaba, 1997. 62p. Dissertação (Mestrado) - Escola Superior de Agricultura "Luiz de Queiroz", Universidade de São Paulo.

SANTOS, P.M. Controle do desenvolvimento de hastes no capim-Tanzânia: um desafio. Piracicaba, 2002. 98 p. Tese (Doutorado) - Escola Superior de Agricultura "Luiz de Queiroz", Universidade de São Paulo.

SAS INSTITUTE Property software release 8. Cary, NC: SAS Institute Inc., 1999. 956p. SAVIDAN, Y.H.; JANK, L.; COSTA, J.C.G. Registro de 25 acessos selecionados de Panicum maximum, Campo Grande: EMBRAPA - CNPGC, 1990. (Documentos, 44). $35 p$.

SCURLOCK, J.M.O.; HALL, D.O. The global carbon sink: a grassland perspective. Global Change Biology, v.4, p.229-233, 1998.

SINGH, K.A. Effect of age, cutting interval, nitrogen and farmyard manure on root growth parameters of forage grasses in na acid Inceptisol. Indian Journal of Agricultural Sciences. v.66, n.1, p.38-44, 1996.

SINGH, B.P. Soil environment and root growth: Introduction to the colloquium. Hort Science, v.33, n.6, p.946-947, 1998. 
SORIA, L.G.T. Produtividade do capim-Tanzânia (Panicum maximum Jacq. cv. Tanzânia) em função da lâmina de irrigação e de adubação nitrogenada. Piracicaba, 2002. 170p. Tese (Doutorado) - Escola Superior de Agricultura "Luiz de Queiroz", Universidade de São Paulo.

TOSI, P. Estabelecimento de parâmetros agronômicos para o manejo e eficiência de utilização de Panicum maximum Jacq. cv. Tanzânia-1 sob pastejo rotacionado. Piracicaba, 1999. 103p. Dissertação (Mestrado) - Escola Superior de Agricultura "Luiz de Queiroz", Universidade de São Paulo.

VOGT, K.A.; BLOOMFIELD, J. Tree root turnover and senescence. In: WAISEL, Y.; ESHEL, A.; KAFKAFI, U. Plant roots: the hidden half. New York: Marcel Dekker, Inc, 1991. p.287-308.

VOORHEES, W.B.; CARLSON, V.A.; HALLAUER, E.A. Root lenght measurement with a computer-controlled digital scanning microdensitometer. Agronomy Journal, v.72, p.847-850, 1980.

WERNER, J.C. Estudo de épocas da adubação nitrogenada em capim Colonião (Panicum maximum Jacq.) para aumento de produção de forragem nas secas. Boletim de Indústria Animal, v. 27/28, n. único, p. 361-368, 1970/71.

WERNER, J.C.; COLOZZA, M.T., MONTEIRO, F.A. Adubação de Pastagens. In: SIMPÓSIO SOBRE MANEJO DA PASTAGEM - Planejamento de Sistemas de Produção em Pastagens. 18. Piracicaba, 2001. Anais Piracicaba: FEALQ, p.129156, 2001.

WRAITH, J.M.; WRIGTH, C.K. Soil water and root growth. Hort Science, v.33, n.6, p.951-959, 1998.

WRIGHT, S.R.; JENNETTE, M.W.; COBLE, H.; RUFTY JUNIOR, T.W. Root morphology of young Glycine max, Senna obtersifolia, and Amaranthus palmeri. Weed Science, v.47, n.6, p.706-711, 1999.

ZIMMER, A.H. Efeito de niveis de nitrogênio e de residuos pós-pastejo sobre a produção, a estrutura e a qualidade das cultivares Aruana e Vencedor de Panicum maximum Jacq. Jaboticabal, 1999. 208p. Tese (Doutorado) - Faculdade de Ciências Agrárias e Veterinárias, Universidade Estadual Paulista. 
APÊNDICES 
Tabela 1. Massa de forragem pré-pastejo e componentes no dossel forrageiro, em seis ciclos de pastejo, para capins e doses de nitrogênio

\begin{tabular}{|c|c|c|c|c|c|c|c|c|}
\hline \multirow[b]{2}{*}{ Fatores } & \multicolumn{6}{|c|}{ Ciclos de Pastejo } & \multirow[b]{2}{*}{ Média } & \multirow[b]{2}{*}{ EPM } \\
\hline & $\begin{array}{c}C 1 \\
09 / 05 \text { a } \\
03 / 07 / 02 \\
\end{array}$ & $\begin{array}{c}\text { C2 } \\
04 / 07 \text { a } \\
26 / 08 / 02 \\
\end{array}$ & $\begin{array}{c}\text { C3 } \\
27 / 08 \text { a } \\
17 / 10 / 02 \\
\end{array}$ & $\begin{array}{c}\mathrm{C} 4 \\
13 / 11 \mathrm{a} \\
23 / 12 / 02 \\
\end{array}$ & $\begin{array}{c}\text { C5 } \\
19 / 12 / 02 \text { a } \\
05 / 02 / 03 \\
\end{array}$ & $\begin{array}{c}\text { C6 } \\
13 / 02 \text { a } \\
28 / 03 / 03 \\
\end{array}$ & & \\
\hline \multicolumn{9}{|c|}{ Total (Mg MS ha $\left.{ }^{-1}\right)$} \\
\hline Aruana & $4,59^{\mathrm{a}}$ & $3,16^{\mathrm{a}}$ & $2,68^{a}$ & $4,27^{a}$ & $4,73^{a}$ & $5,71^{a}$ & $4,19^{a}$ & 0,27 \\
\hline Tanzânia & $5,36^{a}$ & $3,98^{\mathrm{a}}$ & $3,93^{a}$ & $4,09^{a}$ & $4,53^{\mathrm{a}}$ & $6,48^{a}$ & $4,73^{\mathrm{a}}$ & 0,27 \\
\hline \multicolumn{9}{|c|}{ Total (Mg MS ha-1) } \\
\hline $150 \mathrm{~kg} \mathrm{~N}$ & $5,18^{a}$ & $3,22^{a}$ & $2,92^{\mathrm{a}}$ & $3,69^{a}$ & $4,30^{a}$ & $5,90^{a}$ & $4,20^{\mathrm{a}}$ & 0,27 \\
\hline $300 \mathrm{~kg} \mathrm{~N}$ & $4,76^{a}$ & $3,91^{\mathrm{a}}$ & $3,68^{a}$ & $4,67^{a}$ & $4,96^{a}$ & $6,29^{a}$ & $4,71^{\mathrm{a}}$ & 0,27 \\
\hline \multicolumn{9}{|c|}{ Capim (Mg MS ha-1) } \\
\hline Aruana & $3,3^{a}$ & $1,9^{\mathrm{a}}$ & $1,9^{a}$ & $3,7^{\mathrm{a}}$ & $3,9^{a}$ & $4,5^{\mathrm{a}}$ & $3,2^{\mathrm{a}}$ & 0,19 \\
\hline Tanzânia & $4,0^{a}$ & $1,7^{\mathrm{a}}$ & $2,1^{a}$ & $3,7^{\mathrm{a}}$ & $3,9^{a}$ & $5,2^{a}$ & $3,4^{a}$ & 0,19 \\
\hline \multicolumn{9}{|c|}{ Capim (Mg MS ha ${ }^{-1}$ ) } \\
\hline $150 \mathrm{~kg} \mathrm{~N}$ & $3,8^{a}$ & $1,5^{\mathrm{a}}$ & $1,7^{\mathrm{a}}$ & $3,2^{\mathrm{a}}$ & $3,6^{a}$ & $4,8^{a}$ & $3,1^{\mathrm{a}}$ & 0,19 \\
\hline $300 \mathrm{~kg} \mathrm{~N}$ & $3,5^{\mathrm{a}}$ & $2,1^{a}$ & $2,3^{\mathrm{a}}$ & $4,1^{a}$ & $4,3^{a}$ & $4,9^{a}$ & $3,5^{\mathrm{a}}$ & 0,19 \\
\hline \multicolumn{9}{|c|}{ Material Morto (Mg MS ha-1) } \\
\hline $150 \mathrm{~kg} \mathrm{~N}$ & $1,2^{\mathrm{a}}$ & $1,7^{\mathrm{a}}$ & $1,2^{\mathrm{a}}$ & $0,4^{a}$ & $0,7^{\mathrm{a}}$ & $1,0^{\mathrm{a}}$ & $1,0^{\mathrm{a}}$ & 0,08 \\
\hline $300 \mathrm{~kg} \mathrm{~N}$ & $1,1^{\mathrm{a}}$ & $1,8^{\mathrm{a}}$ & $1,4^{\mathrm{a}}$ & $0,5^{a}$ & $0,7^{a}$ & $1,3^{\mathrm{a}}$ & $1,1^{\mathrm{a}}$ & 0,08 \\
\hline \multicolumn{9}{|c|}{ Plantas Invasoras (Mg MS ha-1) } \\
\hline $150 \mathrm{~kg} \mathrm{~N}$ & $0,08^{a}$ & $0,01^{\mathrm{a}}$ & $0,01^{\mathrm{a}}$ & $0,03^{a}$ & $0,03^{a}$ & $0,06^{a}$ & $0,04^{a}$ & 0,01 \\
\hline $300 \mathrm{~kg} \mathrm{~N}$ & $0,12^{\mathrm{a}}$ & $0,01^{a}$ & $0,02^{\mathrm{a}}$ & $0,04^{a}$ & $0,00^{a}$ & $0,04^{a}$ & $0,04^{a}$ & 0,01 \\
\hline
\end{tabular}


Tabela 2. Massa de forragem remanescente pós-pastejo em seis ciclos de pastejo, para doses de nitrogênio

\begin{tabular}{|c|c|c|c|c|c|c|c|c|}
\hline \multirow[b]{2}{*}{ Fatores } & \multicolumn{6}{|c|}{ Ciclos de Pastejo } & \multirow[b]{2}{*}{ Média } & \multirow[b]{2}{*}{ EPM } \\
\hline & $\begin{array}{c}C 1 \\
09 / 05 a \\
03 / 07 / 02 \\
\end{array}$ & $\begin{array}{c}C 2 \\
04 / 07 \text { a } \\
26 / 08 / 02 \\
\end{array}$ & $\begin{array}{c}\text { C3 } \\
27 / 08 \text { a } \\
17 / 10 / 02 \\
\end{array}$ & $\begin{array}{c}\text { C4 } \\
13 / 11 \text { a } \\
23 / 12 / 02\end{array}$ & $\begin{array}{c}\text { C5 } \\
19 / 12 / 02 \text { a } \\
05 / 02 / 03 \\
\end{array}$ & $\begin{array}{c}C 6 \\
13 / 02 a \\
28 / 03 / 03 \\
\end{array}$ & & \\
\hline \multicolumn{9}{|c|}{ Forragem remanescente $\left(\mathrm{Mg} \mathrm{MS} \mathrm{ha}^{-1}\right)$} \\
\hline $150 \mathrm{~kg} \mathrm{~N}$ & $2,5^{\mathrm{a}}$ & $2,0^{\mathrm{a}}$ & $1,7^{\mathrm{a}}$ & $1,3^{a}$ & $2,3^{\mathrm{a}}$ & $2,6^{a}$ & $2,1^{\mathrm{a}}$ & 0,22 \\
\hline $300 \mathrm{~kg} \mathrm{~N}$ & $2,5^{\mathrm{a}}$ & $2,6^{a}$ & $2,3^{a}$ & $1,9^{a}$ & $2,4^{\mathrm{a}}$ & $2,2^{a}$ & $2,3^{a}$ & 0,33 \\
\hline
\end{tabular}

Tabela 3. Acúmulo e taxa média diária de acúmulo de forragem em seis períodos de rebrotação $(R)$, para capins e doses de nitrogênio

\begin{tabular}{|c|c|c|c|c|c|c|c|c|c|}
\hline \multirow[b]{2}{*}{ Fatores } & \multicolumn{6}{|c|}{ Periodos de Rebrotação } & \multirow[b]{2}{*}{ Média } & \multirow[b]{2}{*}{ EPM } & \multirow[b]{2}{*}{ Total } \\
\hline & $\begin{array}{c}\text { R1: } 49 \\
\text { dias }\end{array}$ & $\begin{array}{c}\text { R2: } 43 \\
\text { dias }\end{array}$ & $\begin{array}{c}\text { R3: } 77 \\
\text { dias }\end{array}$ & $\begin{array}{c}\text { R4: } 38 \\
\text { dias }\end{array}$ & $\begin{array}{c}\text { R5: } 43 \\
\text { dias }\end{array}$ & $\begin{array}{c}\text { R6: } 35 \\
\text { dias }\end{array}$ & & & \\
\hline \multicolumn{10}{|c|}{ Acúmulo de forragem (Mg MS ha-1) } \\
\hline Aruana & $2,1^{\mathrm{a}}$ & $0,9^{\mathrm{a}}$ & $0,9^{a}$ & $2,6^{a}$ & $2,8^{a}$ & $3,7^{a}$ & $2,2^{a}$ & 0,28 & $13,0^{a}$ \\
\hline Tanzânia & $3,3^{a}$ & $1,3^{a}$ & $1,1^{a}$ & $1,7^{\mathrm{a}}$ & $3,0^{a}$ & $3,8^{a}$ & $2,4^{a}$ & 0,28 & $14,2^{a}$ \\
\hline \multicolumn{10}{|c|}{ Acúmulo de forragem (Mg MS ha-1) } \\
\hline $150 \mathrm{~kg} \mathrm{~N}$ & $2,8^{\mathrm{a}}$ & $0,7^{a}$ & $0,9^{a}$ & $2,0^{\mathrm{a}}$ & $2,8^{\mathrm{a}}$ & $3,6^{a}$ & $2,1^{a}$ & 0,22 & $12,8^{\mathrm{a}}$ \\
\hline $300 \mathrm{~kg} \mathrm{~N}$ & $2,61^{a}$ & $1,43^{a}$ & $1,05^{a}$ & $2,39^{a}$ & $3,04^{a}$ & $3,92^{a}$ & $2,40^{a}$ & 0,33 & $14,4^{a}$ \\
\hline \multicolumn{10}{|c|}{ Taxa média acúmulo de forragem $\left(\mathrm{kg} \mathrm{MS} \mathrm{ha}^{-1} \mathrm{dia}^{-1}\right)$} \\
\hline Aruana & $43,4^{\mathrm{a}}$ & $19,5^{\mathrm{a}}$ & $11,2^{\mathrm{a}}$ & $67,5^{\mathrm{a}}$ & $66,4^{\mathrm{a}}$ & $90,0^{\mathrm{a}}$ & $49,7^{a}$ & 6,87 & - \\
\hline Tanzânia & $67,9^{a}$ & $29,7^{a}$ & $14,9^{a}$ & $41,8^{a}$ & $83,8^{a}$ & $95,1^{a}$ & $55,5^{a}$ & 6,94 & - \\
\hline \multicolumn{10}{|c|}{ Taxa média acúmulo de forragem $\left(\mathrm{kg} \mathrm{MS} \mathrm{ha}^{-1} \mathrm{dia}^{-1}\right)$} \\
\hline $150 \mathrm{~kg} \mathrm{~N}$ & $57,5^{\mathrm{a}}$ & $16,4^{a}$ & $11,5^{a}$ & $47,2^{a}$ & $71,5^{a}$ & $88,0^{a^{\prime}}$ & $48,7^{a}$ & 5,72 & - \\
\hline $300 \mathrm{~kg} \mathrm{~N}$ & $53,7^{a}$ & $21,8^{a}$ & $14,6^{a}$ & $62,2^{a}$ & $78,7^{a}$ & $97,2^{a}$ & $56,5^{a}$ & 7,91 & - \\
\hline
\end{tabular}


Tabela 4. Altura do dossel forrageiro pós-pastejo em seis ciclos de pastejo

\begin{tabular}{ccccccccc}
\hline \multicolumn{7}{c}{ Ciclos de Pastejo } \\
Fatores & $\mathrm{C} 1$ & $\mathrm{C} 2$ & $\mathrm{C} 3$ & $\mathrm{C} 4$ & $\mathrm{C} 5$ & $\mathrm{C6}$ & Média & EPM \\
& $09 / 05 \mathrm{a}$ & $04 / 07 \mathrm{a}$ & $27 / 08 \mathrm{a}$ & $13 / 11 \mathrm{a}$ & $19 / 12 / 02 \mathrm{a}$ & $13 / 02 \mathrm{a}$ & & \\
\hline $03 / 07 / 02$ & $26 / 08 / 02$ & $17 / 10 / 02$ & $23 / 12 / 02$ & $05 / 02 / 03$ & $28 / 03 / 03$ & \\
$150 \mathrm{~kg} \mathrm{~N}$ & $22,7^{\mathrm{a}}$ & $17,7^{\mathrm{a}}$ & $15,2^{\mathrm{a}}$ & $41,3^{\mathrm{a}}$ & $36,1^{\mathrm{a}}$ & $45,9^{\mathrm{a}}$ & $29,8^{\mathrm{a}}$ & 1,94 \\
$300 \mathrm{~kg} \mathrm{~N}$ & $23,2^{\mathrm{a}}$ & $20,3^{\mathrm{a}}$ & $17,1^{\mathrm{a}}$ & $57,1^{\mathrm{a}}$ & $44,5^{\mathrm{a}}$ & $49,1^{\mathrm{a}}$ & $35,2^{\mathrm{a}}$ & 2,74 \\
\hline${ }^{\text {ab }}$ Médias na mesma coluna seguidas da mesma letra minúscula não diferem entre si $(\mathrm{p}>0,10)$.
\end{tabular}

Tabela 5. Densidade populacional de perfilhos pré-pastejo em seis ciclos de pastejo, para doses de nitrogênio

\begin{tabular}{|c|c|c|c|c|c|c|c|c|}
\hline \multirow[b]{2}{*}{ Capins } & \multicolumn{6}{|c|}{ Ciclos de Pastejo } & \multirow[b]{2}{*}{ Média } & \multirow[b]{2}{*}{ EPM } \\
\hline & $\begin{array}{c}C 1 \\
09 / 05 a \\
03 / 07 / 02\end{array}$ & $\begin{array}{c}C 2 \\
04 / 07 \text { a } \\
26 / 08 / 02\end{array}$ & $\begin{array}{c}\text { C3 } \\
27 / 08 \text { a } \\
17 / 10 / 02\end{array}$ & $\begin{array}{c}C 4 \\
13 / 11 \mathrm{a} \\
23 / 12 / 02\end{array}$ & $\begin{array}{c}\text { C5 } \\
19 / 12 / 02 \text { a } \\
05 / 02 / 03\end{array}$ & $\begin{array}{c}C 6 \\
13 / 02 \text { a } \\
28 / 03 / 03\end{array}$ & & \\
\hline \multicolumn{9}{|c|}{ Perfilhos $m^{-2}$} \\
\hline $150 \mathrm{~kg} \mathrm{~N}$ & $1025^{a}$ & $446^{a}$ & $533^{a}$ & $634^{a}$ & $1070^{a}$ & $1606^{a}$ & $886^{a}$ & 49,16 \\
\hline $300 \mathrm{~kg} \mathrm{~N}$ & $1120^{a}$ & $667^{a}$ & $634^{a}$ & $671^{a}$ & $987^{a}$ & $1489^{a}$ & $928^{a}$ & 39,04 \\
\hline
\end{tabular}

Tabela 6. Médias de crescimento de raizes para as variáveis peso seco, superfície, comprimento e diâmetro nos quatro períodos de rebrotação pós-pastejo (médias de capins, doses de $\mathrm{N}$ e idades de crescimento)

\begin{tabular}{cccc}
\hline $\begin{array}{c}\text { Periodos de } \\
\text { Rebrotação }\end{array}$ & $\begin{array}{c}\text { Peso seco } \\
\left(\mathrm{mg} / \text { sonda*}^{*}\right.\end{array}$ & $\begin{array}{c}\text { Superfície } \\
\left(\mathrm{cm}^{-2} / \mathrm{sonda}^{*}\right)\end{array}$ & $\begin{array}{c}\text { Comprimento } \\
\left(\mathrm{cm} / \text { sonda*}^{*}\right.\end{array}$ \\
\hline R1 & $3,9^{\mathrm{b}}$ & $183,2^{\mathrm{b}}$ & $464,4^{\mathrm{b}}-$ \\
R2 & $12,9^{\mathrm{a}}$ & $622,6^{\mathrm{a}}$ & $1830,2^{\mathrm{a}}$ \\
R3 & $4,7^{\mathrm{b}}$ & $152,9^{\mathrm{b}}$ & $417,2^{\mathrm{b}}$ \\
R4 & $17,0^{\mathrm{a}}$ & $510,1^{\mathrm{a}}$ & $1758,7^{\mathrm{a}}$ \\
\hline
\end{tabular}

${ }^{\text {ab }}$ Médias na mesma coluna seguidas da mesma letra minúscula não diferem entre si $(P>0,10)$.

* volume ocupado pela sonda $=125,6 \mathrm{~cm}^{3}$. 
Tabela 7. Médias de crescimento de raizes para as variáveis peso seco, superfície, comprimento e diâmetro para as quatro idades de crescimento pós-pastejo (médias de capins, doses de $\mathrm{N}$ e idades de crescimento)

\begin{tabular}{cccc}
\hline $\begin{array}{c}\text { Datas de } \\
\text { Avaliação }\end{array}$ & $\begin{array}{c}\text { Peso seco } \\
\left(\mathrm{mg} / \text { sonda*}^{*}\right.\end{array}$ & $\begin{array}{c}\text { Superficie } \\
\left(\mathrm{cm}^{-2} / \mathrm{sonda}^{\star}\right)\end{array}$ & $\begin{array}{c}\text { Comprimento } \\
\left(\mathrm{cm} / \text { sonda*}^{*}\right)\end{array}$ \\
\hline 7DPP & $5,8^{\mathrm{b}}$ & $88,8^{\mathrm{c}}$ & $343,8^{\mathrm{c}}$ \\
14DPP & $5,5^{\mathrm{b}}$ & $294,1^{\mathrm{b}}$ & $758,6^{\mathrm{bc}}$ \\
21DPP & $9,6^{\mathrm{b}}$ & $392,2^{\mathrm{b}}$ & $1247,4^{\mathrm{b}}$ \\
28DPP & $17,6^{\mathrm{a}}$ & $693,6^{\mathrm{a}}$ & $2120,8^{\mathrm{a}}$ \\
\hline
\end{tabular}

7DPP: 7 dias após o pastejo; 14DPP: 14 dias após o pastejo; 21DPP: 21 dias após o pastejo; 28DPP: 28 dias após o pastejo.

${ }^{a b}$ Médias na mesma coluna seguidas da mesma letra minúscula não diferem entre si $(P>0,10)$.

* volume ocupado pela sonda $=125,6 \mathrm{~cm}^{3}$. 